\title{
DRY GRASSLAND VEGETATION IN THE TRANSITION ZONE BETWEEN TWO BIOGEOGRAPHIC REGIONS
}

\author{
Desislava SOPOTLIEVA ${ }^{1, *} \&$ Iva APOSTOLOVA ${ }^{1}$
}

\begin{abstract}
The geographic position of Bulgaria results in a variety of climatic and biogeographic influences on the country's vegetation. We aim to describe the plant diversity of dry grasslands distributed in the transitional belt between the south-eastern European and Mediterranean biogeographic regions in SE Bulgaria, and to reveal if there are any obvious differences in soil properties, presence of life forms and chorotypes between syntaxa. The data set consists of 349 relevés of vascular plants and bryophytes sampled in different semi-natural herbaceous vegetation types. By applying TWINSPAN, we classified 176 relevés of dry grasslands to eight associations and one unranked community. One association and two subassociations are described here for the first time. Data on soil depth, soil moisture, soil $\mathrm{pH}$, humus and total $\mathrm{N}$ content, numbers of different life forms and chorotypes were analysed statistically. The dry grasslands in SE Bulgaria were classified into different vegetation classes sharing the same territory: their communities present similarities in species composition and they have similar ratios of hemicryptophytes/therophytes and Euro-Asiatic/Mediterranean species. Dry grassland vegetation occupies mostly shallow and dry soils that vary slightly in $\mathrm{pH}$, humus content and soil moisture between associations.
\end{abstract}

Keywords: Bulgaria, Festuco-Brometea, Helianthemetea guttati, Koelerio-Corynephoretea.

\begin{abstract}
Izvleček
Različni klimatski in biogeografski vplivi na vegetacijo so pogojeni z geografskim položajem Bolgarije. V članku opisujemo vrstno raznolikost suhih travišč, ki se pojavljajo v prehodnem pasu med jugovzhodno Evropsko in Mediteransko biogeorafsko regijo in razkrivamo, ali obstajajo očitne razlike med sintaksoni v lastnostih tal, življenskih oblikah in horotipih. Podatkovni niz vsebuje 349 vegetacijskih popisov cevnic in mahov, vzorčenih $\mathrm{v}$ različnih polnaravnih zeliščnih vegetacijskih tipih. $\mathrm{Z}$ uporabo TWINSPAN metode smo klasificirali 176 popisov suhih travišč v osem asociacij in eno nerangirano združbo. V članku sta prvič opisani ena asociacija in dve subasociaciji. Statistično smo analizirali podatke o globini, vlažnosti in $\mathrm{pH}$ tal, vsebnosti humusa in skupnega dušika ter število različnih življenskih oblik in horotipov. Suha travišča v JV Bolgariji smo uvrstili $\mathrm{v}$ različne vegetacijske razrede na tem območju: združbe so podobne po vrstni sestavi in imajo podobno razmerje hemikriptofiti/terofiti ter Evroazijske/Mediteranske vrste. Suha travišča uspevajo na pretežno plitvih in suhih tleh, ki se med asociacijami malo razlikujejo $\mathrm{v} \mathrm{pH}$, vsebnosti humusa in vlažnosti tal.
\end{abstract}

Ključne besede: Bolgarija, Festuco-Brometea, Helianthemetea guttati, Koelerio-Corynephoretea.

\section{INTRODUGTION}

Bulgaria is a small country in the central part of the Balkan Peninsula with diverse relief, climate and geology, as well as a rich flora that is reflected in a large number of different plant communi- ties. Its geographic position determines multiple biogeographic influences. The majority of the country falls under the influence of the Central European bioclimate, resulting in broadleaved deciduous forests as potential natural vegetation. Close proximity to the Mediterranean region

\footnotetext{
${ }^{1}$ Institute of Biodiversity and Ecosystem Research, Bulgarian Academy of Sciences, 23, Acad. G. Bonchev Str., 1113 Sofia, Bulgaria. E-mail: dsopotlieva@gmail.com; iva.apostolova@gmail.com

* Corresponding author
} 
is a reason for the presence of small patches of Mediterranean vegetation types, while in northeastern Bulgaria there are stretches of steppe and forest-steppe vegetation, which are affected by a steppic bioclimate. Bondev (2002) has divided the country into three regions in terms of phytogeography: European broadleaved deciduous forests, Euro-Asiatic steppe and forest-steppe, and Mediterranean sclerophytic vegetation. They all belong to Takhtajan's Holarctic Kingdom (Takhtajan 1986). According to recent biogeographic divisions (Gruev \& Kuzmanov 1994, Bondev 2002, Asenov 2006), the Mediterranean sclerophytic region is confined to the southernmost territory of Bulgaria, and traditionally is considered as part of Struma and Mesta river valleys which are situated further west from our study area. The Euro-Asiatic steppe and foreststeppe region is distributed in the eastern part of the country, and the rest of the territory is characterised by European deciduous vegetation.

Following the biogeographic division suggested by Rivaz-Martínez et al. (2004), the study area falls within the Bulgarian part of the ApenninoBalkan province. It neighbours the Thracian part of the Graeco-Aegean province, and forms the boundary between the Mediterranean and Eurosiberian biogeographic regions.

To date, few vegetation studies have been conducted in this part of the country. Sopotlieva (2008) provided an overview of the diversity of the grassland vegetation in her PhD thesis. Several new syntaxa were established, but not effectively published. Studies on halophytic communities and some dry grasslands were conducted in the following years (Sopotlieva \& Apostolova 2007, Tzonev et al. 2008, Sopotlieva 2009, Elíaš et al. 2013).

We regard biogeographical division as a tool for ordering and better understanding the driving mechanisms of plant communities' distribution patterns. Based on current knowledge about spatial distribution of biogeographic regions in Bulgaria, we aim 1) to understand vegetation diversity in the transitional belt between the southeastern European and Mediterranean biogeographic regions; 2) to reveal any obvious differences in soil properties, or patterns of life forms and chorotypes between recognised syntaxa in the boundary area between two biogeographic regions, and 3) to publish effectively some newly described syntaxa.

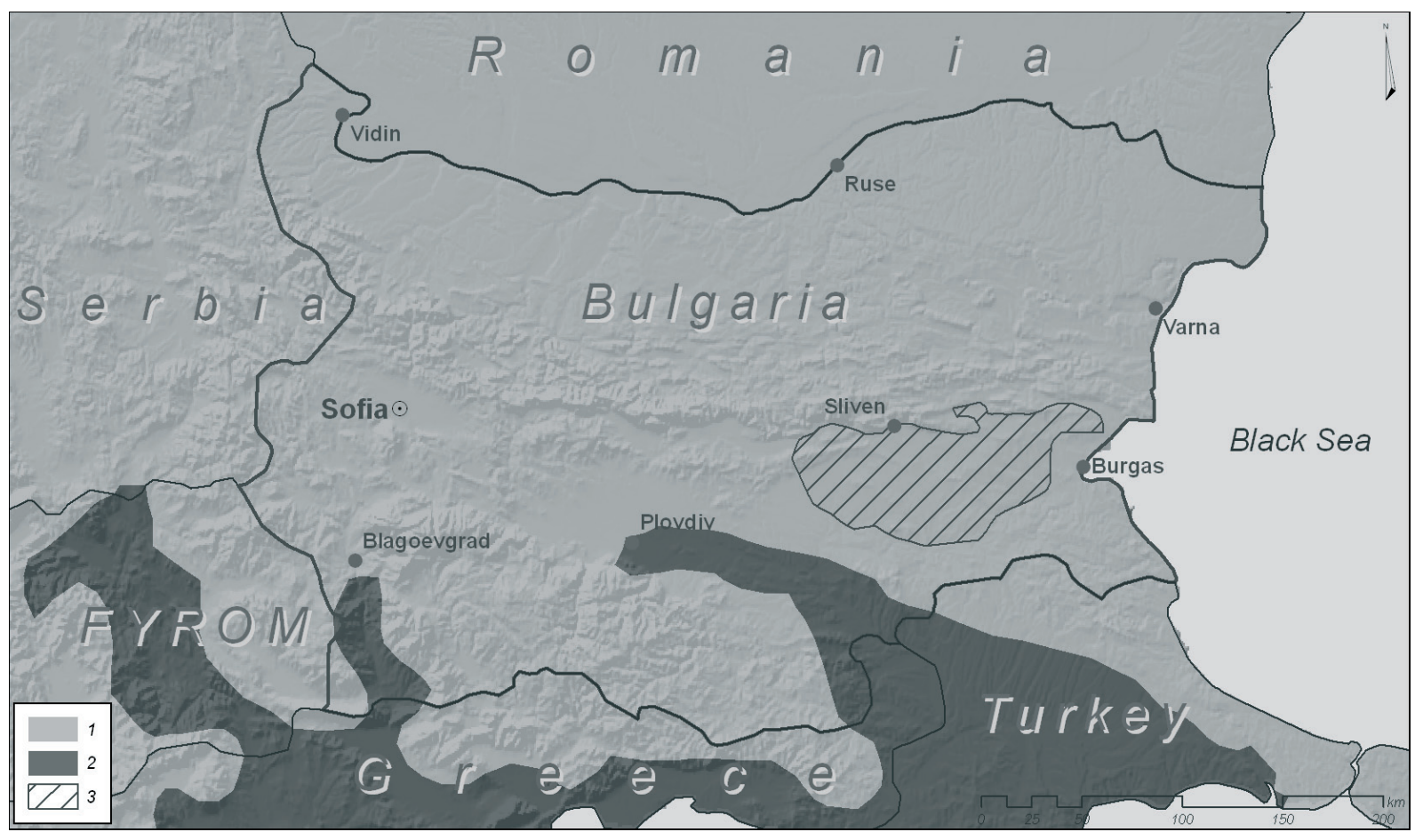

Figure 1: Map of Bulgaria with Eurosiberian (1) and Mediterranean (2) biogeographical regions, according Rivaz-Martínez et al. (2004). The study area is outlined (3).

Slika 1: Zemljevid Bolgarije z Evrosibirsko (1) in Mediteransko (2) biogeografsko regijo po Rivaz-Martínez et al. (2004). Označeno je raziskovano območje (3). 


\section{MATERIAL \& METHODS}

\subsection{STUdy AREA}

The study was conducted in the Straldzha-Aytos phytogeographic region (Bondev 2002). It is situated between 42 and $43^{\circ} \mathrm{N}$ latitude and 26 and $27^{\circ}$ E longitude, in southeastern Bulgaria (Figure 1). The total study area is approximately $5500 \mathrm{sq}$. km and mostly belongs to the Toundzha river hilly valley. The relief is diverse, including lowlands, as well as hilly regions of the easternmost parts of the Balkan Mountains (Stara planina), Sredna Gora Mountain, and several other isolated hills. The altitude reaches up to $670 \mathrm{~m}$ a.s.l. The region is characterised by diverse geology including volcanic rocks (basalts) and sediments (mergels, sandstone and limestone). Vertisols, fluvisols and solonetz soil types are characteristic for the flat areas, while the hills are mainly covered by luvisols and leptosols (Ninov 2002).

The climate is mild with a mean annual temperature of $12.3^{\circ} \mathrm{C}$ and annual precipitation of $531 \mathrm{~mm}$ (unpublished data provided by Bulgarian National Institute of Meteorology and Hydrology, Bulgarian Academy of Sciences). The majority of the Straldzha-Aytos phytogeographic region is considered a separate, transitional climatic region between Continental and Mediterranean, according to current climatic division of Bulgaria (Velev 2002).

\subsection{VEgEtation AND SOIL SAMPLING, SOIL ANALYSES}

A total of 349 relevés were sampled following the Braun-Blanquet approach (Braun-Blanquet 1965; Westhoff \& van der Maarel 1980) in a variety of semi-natural herbaceous vegetation types (dry, mesic and salt-rich). We placed a minimum of one plot in each stand that we subjectively considered visually homogeneous in terms of vegetation structure and floristic composition. All plots were square-shaped with an area of $16 \mathrm{~m}^{2}$ (Chytrý \& Otýpková 2003). The abundance and cover of species were estimated on the nine-grade modified scale of Braun-Blanquet (Westhoff \& van der Maarel 1980). The total cover of vegetation was estimated in percentage. Altitude and coordinates were measured by GPS Garmin Etrex Summit (WGS 84 system) with altimeter calibrated by current atmospheric pressure. Slope was estimat- ed by visual deviation from an imaginary vertical line, soil depth was evaluated on a three-level scale (shallow, medium deep and deep) and soil moisture was similarly evaluated as dry, moist or wet. Observed present grazing intensity was coded as follows: 0 - no grazing, 1 - low intensity grazing, 2 - moderate intensity grazing, 3 - intensive grazing. The data set has been entered into the Bulgarian Vegetation Database (Apostolova et al. 2012; GIVD ID EU-BG-001) stored in TURBOVEG software (Hennekens \& Schaminée 2001).

Nomenclature of the species followed Kozhuharov (1992) for vascular plants and Natcheva \& Ganeva (2005) for mosses. In some cases, we merged narrowly defined species or subspecies as follows: (S) Anagallis arvensis - Anagallis arvensis, $A$. arvensis subsp. arvensis, A. arvensis subsp. foemina; (S) Bupleurum commutatum - Bupleurum commutatum, B. commutatum subsp. commutatum, B. commutatum subsp. aequalis; (S) Elymus elongatus - Elymus elongatus, E. elongatus subsp. ponticus; (S) Elymus hispidus - Elymus hispidus, E. hispidus subsp. barbulatus, E. hispidus subsp. hispidus; (S) Hieracium praealtum - Hieracium praealtum, H. praealtum subsp. bauchinii; (S) Onobrychis alba - Onobrychis alba, O. alba subsp. calcarea; (S) Trifolium repens - Trifolium repens, T. repens subsp. repens; (S) Vicia pannonica - Vicia pannonica, V. pannonica subsp. striata; (S) Taraxacum sp. - Taraxacum species, Taraxacum officinale.

The chorotypes are given according to Assyov et al. (2002) for vascular plants and according to Ganeva \& Düll (1999) for mosses. Numerous chorotypes are combined in several groups, as follows: Alpine (Alp) - incl. also Alpine-Mediterranean (Alp-Med), Alpine-Balkan (Alp-Bal), subalpine (subAlp); Balkan (Bal) - incl. also BalkanAnatolian (Bal-Anat), Balkan-Dacian (Bal-Dac), Appenino-Balkan (Ap-Bal), Pannonian-Balkan (Pann-Bal); Boreal - incl. also sub Boreal; European (Eur) - incl. also European-Mediterranean (Eur-Med), European-Pontic (Eur-Pont), European-sub Mediterranean (Eur-subMed), EuropeanNorth American (Eur-NAm); Europan-Asiatic (Eur-As) - incl. also European-Central Asiatic (Eur-CAs), European-Siberian (Eur-Sib), sub Mediterranean-Asiatic (subMed-As), subMediterranean-Siberian (subMed-Sib), European-Oriental-Turanian (Eur-OT), Temperate (Temp; for moss species); Mediterranean (Med) - incl. also Mediterranean-Asiatic (Med-As), MediterraneanCentral Asiatic (Med-CAs), sub Mediterranean 
(subMed); Pontic (Pont) - incl. also Pontic-Asiatic (Pont-As), Pontic-Central Asiatic (Pont-CAs), Pontic-Mediterranean (Pont-Med), Pontic-subMediterranean (Pont-subMed), Pontic-Siberian (Pont-Sib). The life forms were assessed based on data on the species' biological types provided by Kozhuharov (1992).

Soil samples were collected within the vegetation sample plots at $5-10 \mathrm{~cm}$ depth. The samples were air-dried. The pre-treatment of samples for chemical analyses followed ISO 11464:1994 (E). Basic soil properties were measured such as $\mathrm{pH}$, humus and total nitrogen content. Soil reaction was measured in water solution using a 1:5 soil:water ratio and using the Jenway3310 $\mathrm{pH}$-meter (ISO 10390:1994 (E)). Humus was determined according to the modified Turin method (Kononova 1966) and total nitrogen content according to the modified Kjeldahl method (Donov et al. 1974). Analyses were performed in the Analytical Laboratory of the Institute of Biodiversity and Ecosystem Research, Bulgarian Academy of Sciences, Sofia.

\subsection{Classification And Statistical ANALYSES}

We applied a "top down" analysis, i.e. in the first step we tried to identify major vegetation types (classes and alliances), and then within the alliances to distinguish different associations. Different numerical methods were used - TWINSPAN with three pseudospecies cut-levels $(0,5,25 \%)$ and Cluster Analysis with different combinations of distance measures and group linkage methods (Relative Sorensen \& Flexible beta $(\beta=-0.25)$; Relative Sorenesen \& Ward's method, Relative Euclidian \& Ward's method, etc.). TWINSPAN provided the clearest ecological interpretation of the resulting vegetation types and roughly corresponded to the phytosociological alliances. These vegetation types were then checked by the statistical tendency of species to have a joint occurrence in particular vegetation type by use of the Cocktail method (Bruelheide 1995), using the phi-coefficient (Chytrý et al. 2002). Based on the results of the Cocktail method, several relevés were manually moved within the groups for better representation of the diagnostic species groups. Finally, the vegetation groups were checked using the Frequency-Positive-Fidelity Index (Tichý 2005). Plant species were ordered in groups by fidelity. The latter was calculated by phi-coefficient of association, applied to the classified data set with equalised sizes of clusters (Tichý \& Chytrý 2006). As a result 296 relevés were classified into nine alliances (Sopotlieva 2008). Dry grassland vegetation types were subjected to further classification to association level and analyses on floristic and ecological properties. Associations were established within each alliance after applying TWINSPAN. Vegetation classes, alliances and associations were recognised after referring to the appropriate literature for Central Europe and Mediterraniean region (e.g. Chytrý (ed.) 2007; Chytrý \& Tichý 2003; Klika 1931, 1933, 1934, 1936, 1939; Mucina 1997; Oberdorfer (ed.) 1993; Rivas-Martínez et al. 2001; Royer 1991; Valachovič \& Maglocký 1995), as well as for the neighbouring countries (Horvat 1962; Horvat et al. 1974; Horvatić 1963, 1975; Jovanović-Dunjić 1955; Kojić et al. 1997, 1998; Micevski 1970, 1977, 1978; Pop 1968, 1977; Pop et al. 2002; Roman 1974; Sanda et al. 1997, 1999). The same literature sources were used to allocate species to higher syntaxonomic units.

We tested for differences in some environmental and vegetation parameters with one-way analyses of variance (ANOVAs) carried out in STATISTICA 9 (StatSoft 2009). We tested whether the prerequisites of ANOVA models (normal distribution, equal variance) were sufficiently met by visually inspecting the distribution of the residuals (Quinn \& Keough 2002). In addition, we used Tukey's HSD post hoc test at $\alpha=0.05$ to identify significant differences among groups of syntaxa.

\section{RESULTS}

Dry grasslands make up the majority of the studied vegetation. We assigned 176 relevés of dry grasslands collected in the Straldzha-Aytos phytogeographic region to eight associations and one unranked community (Table 1).

\subsection{SyntaXonomical SCHEME AND NOMENCLATURAL NOTES}

Our syntaxonomical scheme mainly follows the traditional concepts for Festuco-Brometea and Koelerio-Corynephoretea, but also proposals of Rodwell et al. (2002) for the position of Trifolion 
cherleri within higher units, and recent investigations of Bulgarian grasslands, especially for Saturejion montanae (Pedashenko et al. 2013).

Class: Festuco-Brometea Br.-Bl. \& Tx. ex Klika \& Hadač 1944

Order: Festucetalia valesiaca Soó 1947

Alliance: Festucion valesiacae Klika 1931

Association: Bothriochloetum ischaemi Krist 1937

subassociation: typicum

subassociation: asperuletosum cynanchicae Sopotlieva \& Apostolova 2014 [see below]

Association: Festuco valesiacae-Stipetum capillatae Sillinger 1930

Association: Medicagini-Festucetum valesiacae Wagner 1941

Association: Trifolio arvensis-Festucetum valesiacae Sopotlieva \& Apostolova 2014 [see below]

Chrysopogon gryllus-community

Order: Stipo pulcherrimae-Festucetalia pallentis Pop 1968

Alliance: Saturejion montanae Horvat et al. 1974

Association: Euphorbio myrsinitae-Bothriochloetum ischaemi R. Jovanović 1955 subass. medicaginetosum rhodopaeae Sopotlieva \& Apostolova 2014 [see below]

Class Helianthemetea guttati (Br.-Bl. in Br.-Bl. et al. 1952) Rivas Goday \& Rivas-Martínez 1963

Order: Helianthemetalia guttati Br.-Bl. in Br.-Bl. et al. 1940

Alliance: Trifolion cherleri Micevski 1970

Association: Erysimo-Trifolietum Micevski 1977

Association: Poo bulbosae-Achilletum pseudopectinatae Sopotlieva 2009

Class: Koelerio-Corynephoretea Klika in Klika \& Novák 1941

Order: Corynephoretalia canescentis Klika 1934

Alliance: Thero-Airion Tx. ex Oberdorfer 1957

Association: Vulpietum myuri Philippi 1973

\section{Nomenclatural notes on new syntaxa}

Associations

Trifolio arvensis-Festucetum valesiacae Sopotlieva \& Apostolova ass. nov. hoc loco

Typus: Relevé 5 in Table 5 of this publication [Holotypus hoc loco]

Diagnostic species: Odontites serotina, Potentilla neglecta, Herniaria hirsuta, Carex praecox, Elymus hispidus.
Subassociations

Bothriochloetum ischaemi Krist 1937 asperuletosum cynanchicae Sopotlieva \& Apostolova subass. nov. hoc loco

Typus: Relevé 51 in Table 2 of this publication [Holotypus hoc loco]

Differential species: Asperula cynanchica, Trifolium arvense, Bromus squarrosus, Euphorbia myrsinites, Teucrium polium, Koeleria nitidula, Convolvulus cantabrica, Ceratodon purpureus, Chrysopogon gryllus, Minuartia caespitosa, Helianthemum salicifolium.

Euphorbio myrsinitae-Bothriochloetum ischaemi R. Jovanović 1955 medicaginetosum rhodopaeae Sopotlieva \& Apostolova subass. nov. hoc loco Typus: Relevé 14 in Table 7 of this publication [Holotypus hoc loco]

Differential species: Grimmia pulvinata, Echinops ritro, Paronychia cephalotes, Medicago rhodopaea, Weissia wimmeriana, Scleranthus annuus, Sedum acre, Ajuga chamaepytis, Inula aschersoniana, Crupina vulgaris, Didymodon acutus, Helianthemum salicifolium, Koeleria nitidula, Bombycilaena erecta, Hypericum rumeliacum, Minuartia caespitosa, Hippocrepis ciliata, Pleurochaete squarrosa, Centaurea ovina subsp. besserana, Koeleria brevis.

\subsection{Outlines OF VEGETATION TYPES}

The association Bothriochloetum ischaemi (Table 2) includes plant communities dominated by Dichanthium (Bothriochloa) ischaemum. They have a closed horizontal structure with total coverage ranging between 70 and $100 \%$. Total species richness is 239 vascular plant species and average number of species per relevé is 24 . The biological spectrum of the association shows a predominance of hemicryptophytes (50\%), but also significant presence of therophytes (46\%). Other groups as chamaephytes (2\%), cryptophytes (1\%) and species with unidentified life form (1\%) play a negligible role in the communities. The association is characterised by high presence of species with continental-steppic distributions (including European, Euro-Asiatic and Pontic chorotypes). They share $54 \%$ of the total floristic composition. The Euro-Asiatic species prevail (26\%). Surprisingly, Mediterranean species are the second most numerous group represented by $24 \%$. The regional specificity is revealed by 16 Balkan endemic species. 


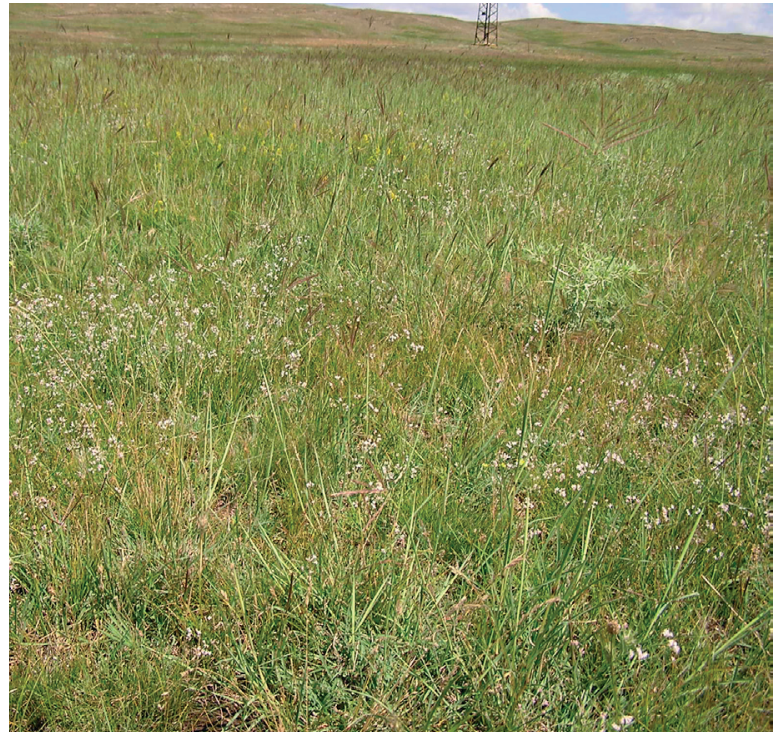

Figure 2: Stand of Bothriochloetum ischaemi asperuletosum cynanchicae close to Dragantsi village.

Slika 2: Sestoj asociacije Bothriochloetum ischaemi asperuletosum cynanchicae v bližini vasi Dragantsi.

The heterogeneity within the sampled communities was the reason for defining two subassociations: typicum and asperuletosum cynanchicae. Asperuletosum cynanchicae (Figure 2) is a new subassociation and includes communities of more xerothermic environments as compared to the typical one. It is distinguished by 12 differential species (see Table 2). According to our results, the differential species group of subass. typicum should be supplemented by Achillea setacea, Rumex pulcher, Carduus nutans and Bromus arvensis, which show high constancy there. On the other hand, Crepis setosa has extremely broad distribution and should be excluded from the differential species group of the typical subassociation.

Figure 3: Diagrams for a) humus content, b) total $\mathrm{N}$ content and c) $\mathrm{pH}$ of soils for the ten studied plant communities.

Slika 3: Grafi za a) vsebnost humusa, b) skupen dušik in c) $\mathrm{pH}$ tal $\mathrm{v}$ desetih proučevanih rastlinskih združbah.

Numbers represent the following syntaxa:

1 - Bothriochloetum ischaemi typicum, 2 - Bothriochloetum ischaemi asperuletosum cynanchicae, 3 - Festuco valesiacaeStipetum capillatae, 4 - Medicagini-Festucetum valesiacae, 5 - Trifolio arvensis-Festucetum valesiacae, 6 - Chrysopogon gryllus community, 7 - Euphorbio myrsinitae-Bohtriochloetum medicaginetosum rhodopaeae, 8 - Erysimo-Trifolietum, 9 - Poo bulbosae-Achilletum pseudopectinatae, 10 - Vulpietum myuri

$\circ$ : mean value; $\square: \pm$ standard error; $\top^{\perp}$ : non-outlier range; $\bullet$ : outliers; $\diamond$ : extremes
Ecology: Communities of both subassociations occupy low altitudes, but stands of asperuletosum cynanchicae occur on steeper and preferably southern slopes (Table 9). Soil pH shows similar values, but the typical subassociation occupies soils more enriched by organic matter than asperuletosum cynanchicae (Figure 3 ).
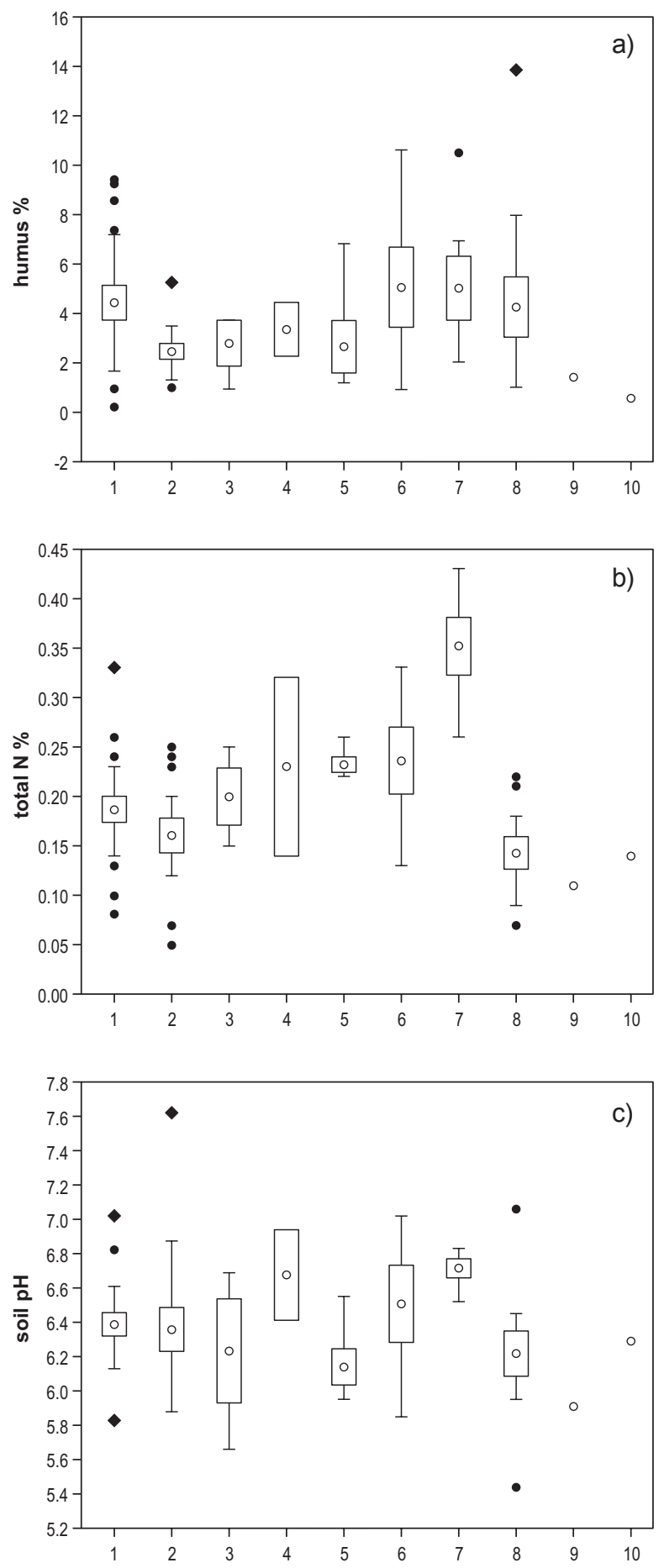
Distribution: Bothriochloetum communities are distributed all over the study area.

Remark: The original diagnosis of this association made by Krist in 1937 was not avilable. In the overview on Dichanthium (Bothriochloa) ischaemum communities in Romania, Pop (1977) did not included any source from this author.

The association Festuco valesiacae-Stipetum capillatae represents communities dominated by Festuca valesiaca and Stipa capillata (Table 3). Total cover varies between 50 and 95\%. A total of 113 vascular plants were recorded in this association, with an average of 24 species per relevé. Although both dominant species are hemicryptophytes, the biological spectrum of the association shows a prevalence of therophytes (50\%). Hemicryptophytes make up almost all the other half of species (47\%). Less numerous are cryptophytes $(2 \%)$, chamaephytes $(0.9 \%)$ and other, not specified species (1\%). Mediterranean (27\%) and Euro-Asiatic (21\%) species prevail. Regional characteristics are linked to nine Balkan species.

Ecology: The habitats of this association are distributed between 120 and $330 \mathrm{~m}$ a.s.l. altitude and over a wide range of aspects. Soils are shallow, dry (100\% of stands), with relatively high humus content and slightly acidic reaction (mean pH 6.23) (Figure 3).

Distribution: Communities of this association are distributed predominantly in the northern part of investigated area.

The association Medicagini-Festucetum valesiacae includes closed stands (average vegetation cover 88\%), dominated by Festuca valesiaca or Dichanthium (Bothriochloa) ischaemum (Table 4). A total of 109 species are recorded within this vegetation type, while the mean species richness per relevé is 35 species. Hemicryptophytes prevail (55\%), but with a significant presence of therophytes (43\%). Chamaephytes and cryptophytes are represented only by one species each. Mediterranean chorotypes prevail, representing $33 \%$ of species, and within this group the sub-Mediterranean species are most common (20\% of all species). Balkan endemics are $5.5 \%$ of the species of the association.

Ecology: This vegetation type was recorded on slightly inclined, north and west facing slopes. Soil properties show slightly alkaline soil reaction (Figure 3).

Distribution: Stands of association are registered all over the study area.
The association Trifolio arvensis-Festucetum valesiacae includes species rich (mean 28.9 species per relevé, total 124 species) dry grasslands dominated by Festuca valesiaca (in most relevés). This vegetation type could be considered as transitional between Festuco-Brometea and Koelerio-Corynephoretea due to its floristic composition and presence of characteristic species from both classes (Table 5). More than half of species are hemicryptophytes (54\%), but the therophytes are also numerous (42\%). Cryptophytes are $3 \%$, and there is only one species with unidentified life form (0.8\%). Euro-Asiatic species prevail (24\%) in the floristic composition, followed by Mediterranean (20.2\%). Endemic plants are represented by eight Balkan species.

Ecology: This community occupies slightly inclined slopes of various aspects, at altitudes between 120 and $324 \mathrm{~m}$ a.s.l. Soils are humus poor with slightly acidic reaction (Figure 3).

Distribution: This association occupies small areas in different parts of the studied region.

A community dominated by Chrysopogon gryllus is recognised by the analysis within the Festucion valesiacae alliance (Table 6). It remains unclassified as does not contain a well defined group of diagnostic species, as well as heterogenous floristic composition and ecological patterrns. The vegetation has closed horizontal structure, with the highest mean of total coverage among all vegetation units presented here, but low plant diversity. The biological spectrum shows that hemicriptophytes represent $58 \%$, and therophytes $38 \%$, of the community's total species number. More numerous within the community are the Euro-Asiatic (27\%) species.

Ecology: This community develops mostly on flat terrains at various altitudes. Soils are of medium depth with very diverse humus content ranging between 0.95 to $10.64 \%$. Soil reaction is slightly acidic ( $\mathrm{pH}$ 5.85) to neutral ( $\mathrm{pH}$ 7.02) (Figure 3).

Distribution: Chrysopogon gryllus dominated communities were found in all parts of the studied region.

Open dry grasslands on calcareous terrains are classified within the Euphorbio myrsinitae-Bothriochloetum association and particularly as a proposed new subassociation, the medicaginetosum rhodopaeae (Table 7, Figures 4 and 5). This vegetation is characterised by the absence of any 


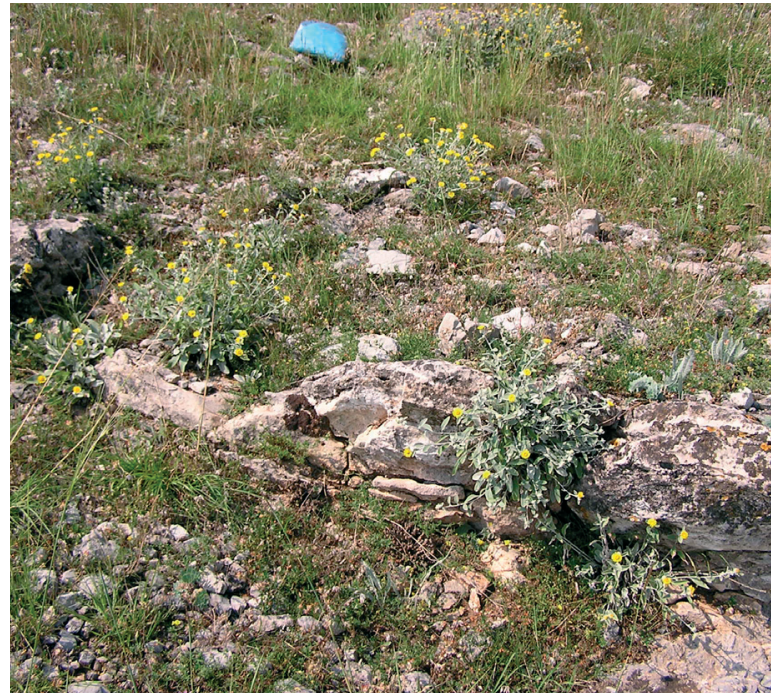

Figure 4: Stand of Euphorbio myrsinitis-Bothriochloetum medicaginetosum rhodopaeae with Inula aschersoniana at Karabair hill.

Slika 4: Sestoj asociacije Euphorbio myrsinitis-Bothriochloetum medicaginetosum rhodopaeae $\mathrm{z}$ vrsto Inula aschersoniana na hribu Karabair.

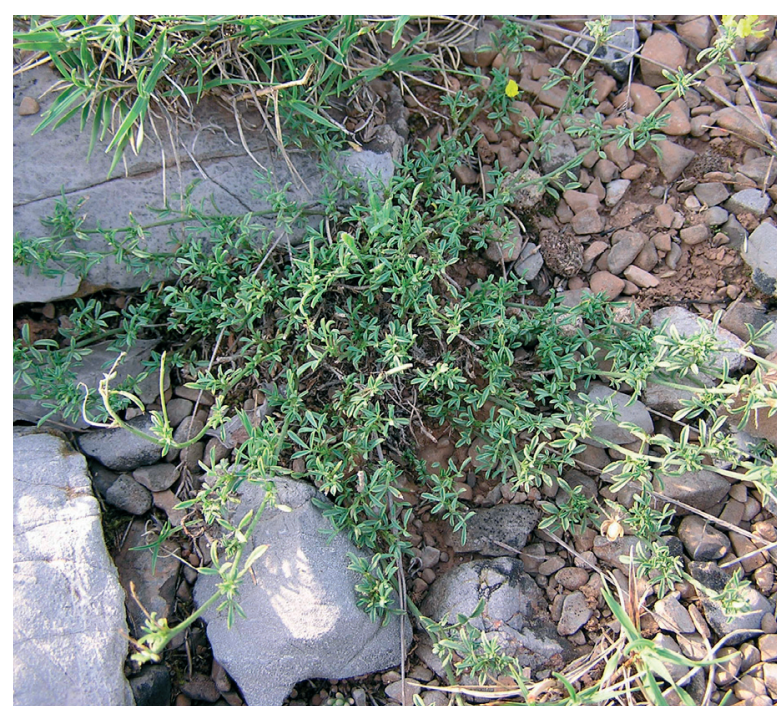

Figure 5 (Slika 5): Medicago rhodopaea Velen.

evident dominant species, as well as by high species richness. The biological spectrum is as follows: hemicryptophytes: $64 \%$, therophytes: $29 \%$, cryptophytes and chamaephytes: $4 \%$ each. Mediterranean chorotypes represent $28 \%$ of the association's species. Endemics are represented by thirteen Balkan and one Bulgarian endemic species.

Ecology: The communities develop on steep slopes with predominantly southern exposition at altitudes between 145 and 356 m a.s.l. Soils are very shallow and the presence of bare rock is common. Humus content is on average 5.04 $\%$, and total nitrogen content is the highest here among the sampled vegetation types (Figure 3 ).

Distribution: Stands of this subassociation were found in the northwestern part of the Straldzha-Aytos region (Karabair hill, the slopes of Stara Planina Mt., above Shivachevo town and east of Sliven town, Svetiiliski hills and slopes of Sredna gora Mt., close to the town of Nova Zagora). The spatial distribution of this subassociation is linked to Triassic limestones.

The association Erysimo-Trifolietum has been thoroughly described by Sopotlieva \& Apostolova (2007) (see Table 1 in Sopotlieva \& Apostolova 2007). It includes predominantly closed and species rich communities. The dominant species vary among its different stands.

Ecology: This vegetation type occupies the highest altitudes of the study area and it develops on slightly inclined slopes. Total N content is relatively low, while soil reaction varies from medium acidic (5.44) to neutral (7.06) (Figure 3).

Distribution: Most of the stands are in the western part of study area and only scattered stands were found in the eastern part.

The association Poo bulbosae-Achilletum pseudopectinatae includes communities with semi-open to closed stands of the Balkan endemic species Achillea pseudopectinata (syn. A. depressa), co-dominated by Poa bulbosa and Thymus striatus (see relevés 1-8 in Table 1 in Sopotlieva 2009). Detailed information about this association is published by Sopotlieva (2009).

Ecology: The communities develop on shallow or medium depth dry soils, on predominantly south or west exposed slightly inclined slopes.

Distribution: It is distributed in the northeastern part and specifically on Mala Aytoska Mt. and on hills close to the town of Karnobat. Only one relevé originates from the central part of StraldzhaAytos region (Konyovo village, Sliven district).

Three stands dominated by Vulpia myurus, were classified within the Vulpietum myuri association (Table 8). They are characterised by high total cover, but poor species richness (they have the lowest mean number of species per relevé). Hemicryptophytes prevail, being represented by 21 species (55\%) and 16 species are therophytes (42\%). The majority of species are Euro-Asiatic 
(34\%), followed by Mediterranean (21\%) and European (18\%) species.

Ecology: This vegetation type occupies slightly inclined slopes. Soils are dry, shallow or of medium depth, with low humus content $(0.62 \%)$ and slightly acidic reaction.

Distribution: Stands are distributed in the southern (Zlatari village), eastern (Devetak village) and northern (Lozica village) parts of the study area.

\subsection{ENVIRONMENTAL AND FLORISTIC PECULIARITIES OF THE VEGETATION TYPES}

The biological features such as species richness and total plant cover tend to be more diverse, and split the studied communities in four major groups (Table 9). Koelerio-Corynephoretea vegetation, represented by Vulpietum myuri, shows the lowest species richness. In contrast, the sub-Mediterranean vegetation of Helianthemetea guttati, represented by Erysimo-Trifolietum, is the most species rich. Vegetatation coverage has low values for the relatively species rich communities (Euphorbio myrsinitae-Bothriochloetum, Festuco valesiacae-Stipetum capillatae), while a closed structure prevails in communities composed of tufted grasses (Chrysopogon gryllus-community, Bothriochloetum ischaemi typicum). Total vegetation cover varies widely within most vegetation types.

The altitudinal range within the study region is not large. However, the lowest altitudes in the lowlands are occupied by ruderal-like communities of the typicum subassociation of Bothriochloetum ischaemi. Due to widespread agricultural usage of lowland territories, most established seminatural dry grassland types occur on slightly inclined slopes of hills with shallow soils and very similar soil characteristics in terms of $\mathrm{pH}$ and total N (Table 9 and Figure 3). Almost all vegetation plots (95\%) occur on dry soils. The most common type of land use in the studied grasslands was grazing ( $82 \%$ of plots), with $46 \%$ of the active pastures being used at low intensity. Studied grasslands are of secondary origin and have been managed by grazing for long time. Recently, the grazing pressure has reduced considerably and during the field research many of the sampled plots were in abandoned pastures. Low intensity grazing maintains the grasslands in their current state. Rarely, intensive grazing was recorded in
Bothriochloetum communities and in stands with high abundance of Festuca valesiaca. (Figure 6).

Euro-Asiatic and Mediterranean chorotypes prevail in the species composition in all plant communities (Table 10). Usually, these main chorotypes have very similar proportions. A difference of more than $10 \%$ between EuropeanAsiatic and Mediterranean elements occur only in two plant associations - Medicagini-Festucetum and Vulpietum myuri. Adventive and Alpine species appear in species composition accidentally. Endemics are represented by Balkan species.

Hemicryptophytes are the most species rich life form among all studied dry grassland types besides the Festuco-Stipetum association. Therophytes have a significant presence within all the identified types, which is a result of the pronounced Mediterranean influence.
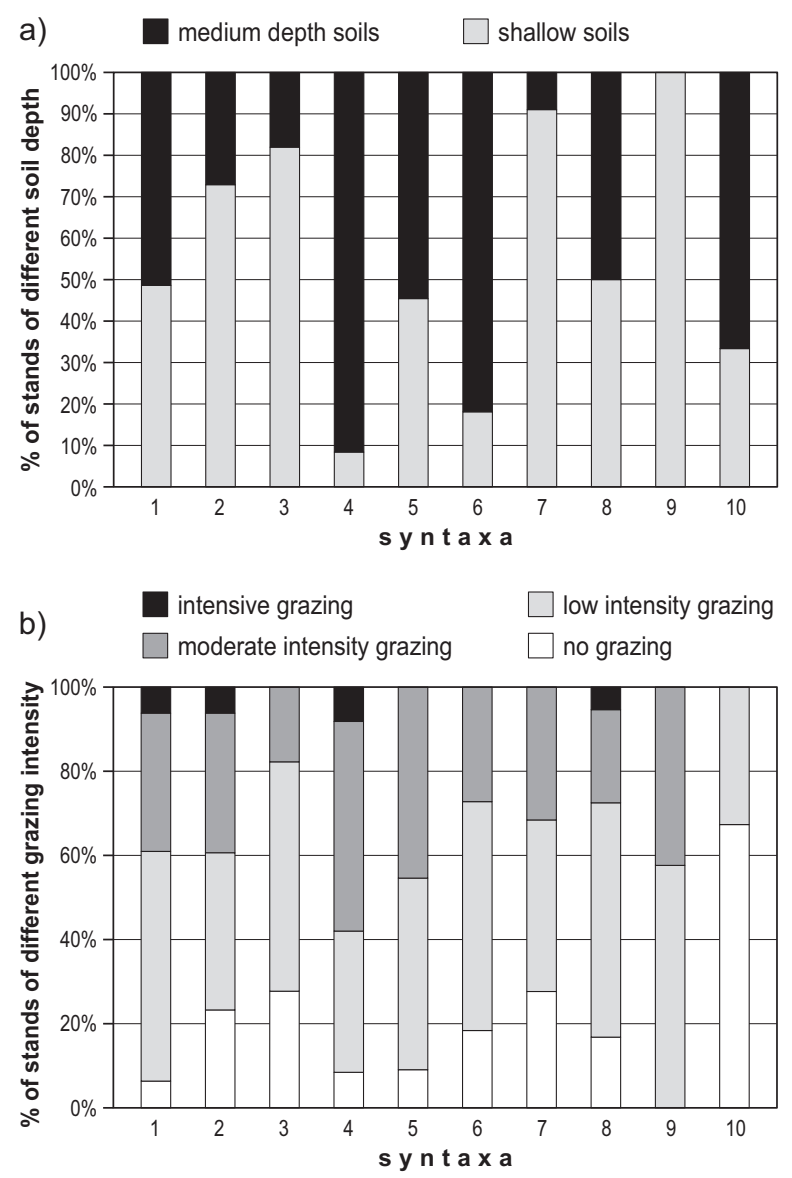

Figure 6: Percentage of a) soil depth categories and b) grazing intensity categories within the ten studied plant communities. Syntaxa are as in Figure 3.

Slika 6: Odstotek a) kategorij globine tal in b) kategorij intenzivnosti paše $\mathrm{v}$ desetih proučevanih rastlinskih združbah. Sintaksoni so označeni kot na sliki 3 . 


\section{DISSCUSSION}

Dry grasslands in southeastern Bulgaria are represented by Central European vegetation types, such as Festuco valesiacae-Stipetum capillatae, Medicagini-Festucetum and Vulpietum myuri, as well as vegetation types typical for Southeastern Europe (Bothriochloetum and Chrysopogon gryllus-communities) and sub-Mediterranean herbaceous vegetation, like Euphorbio myrsinitae-Bothriochloetum and Erysimo-Trifolietum. Occupying the same territory under a sub-Mediterranean climatic influence, all established communities share similar floristic characteristics (see Table 1). Vegetation types that belong to different classes are rather rich in sub-Mediterranean species and therophytes. We found that sub-Mediterranean chorotypes share high percentage of the species composition in almost all vegetation types, which strongly indicates the influence of the relatively warm climate of this area. Chamaephytes seem to be the prevailing life form traditionally associated with temperate regions, but therophytes also have a significant share and constitute up to half of all species in all associations.

Bothriochloa (Dichanthium) ischaemum is widespread across Bulgaria and is a typical dominant species of dry grasslands in the lowlands and the lower mountain zone. So far, the association Bothriochloetum ischaemi has been recorded in northern (Tzonev 2002) and northeastern Bulgaria (Apostolova \& Meshinev 2006). The association is widespread also in Romania (Pop 1977). Our new records from southeastern Bulgaria enlarge its areal to the South. A prevalence of hemicryptophytes is more pronounced in Romanian communities, reaching up to $72 \%$, while the proportion of therophytes is not higher than 20-30\% (Pop 1968, 1977; Roman 1974; Pop et al. 2002). The number of therophytes in our samples is higher.

The distribution of Festuco valesiacae-Stipetum capillatae is known for the area of Central Europe, from central Germany, Czech Republic and Slovakia to Hungary (Chytrý et al. 2007). This correlates with the position of the association in the classification scheme of Royer (1991) in the "western group associations" of the suballiance Eu-Festucenion rupicolae Soó 1971. However, the association is also given for Ukraine, together with other associations dominated by Stipa capillata as Stipetum capillatae Dziubaltowski 1925,
Furineo calcareae-Stipetum capillatae (Kukovitsa et al. 1994) Kukovitsa in V. Solomakha 1996, Carici humilis-Stipetum capillatae Tkachenko, Movchan \& V. Solomakha 1987 (Solomakha 1996). Communities of Stipa capillata co-dominanted by Festuca valesiaca and Bothriochloa (Dichanthium) ischaemum with similar species composition are classified within the association Stipetum capillatae (Hueck 1931) Krausch 1961 by Romanian researchers (Sanda et al. 1997, Pop et al. 2002). Horvat et al. (1974) mention the association Festuca valesiaca-Agropyrum pectinatum-Stipa capillata Puşcaru-Soroceanu 1963 as part of the steppe vegetation in Dobruja. In our opinion, the studied communities in Bulgaria show a higher degree of floristic similarity with Central European ones than with the steppe communities of Romania. At the same time, our communities contain a significant presence of Koelerio-Corynephoretea species and Balkan endemics that distinguishes them from Central European stands.

Another Central European vegetation type recorded in the study area is Medicagini-Festucetum. Its position in Royer's syntaxonomical scheme is also in the "western group of associations". However, the same author proposed that some of its stands to be classified within Salvio-Festucetum pontico-romanicum Ciocirlan 1968, and therefore to the "southern group of associations", which are distributed in Central and Eastern Romania, Bulgaria and probably part of Ukraine (Royer 1991). In our samples classified within Medicagini-Festucetum, the number of character species seems to decrease towards the southern localities. The prevalence of sub-Mediterranean species and the presence of Balkan endemics give reason to propose a new sub-association or variant. However, due to the limited number of relevés and restricted study region, a more precise classification is avoided at this time. These data conclusively demonstrate that the range of the association Medicagini-Festucetum reaches Bulgaria. Collection of more vegetation data from Bulgaria and comparison with the communities from southern Romania will allow a better determination of the internal heterogeneity and geographical differentiation within this association.

The proposed new plant association Trifolio arvensis-Festucetum valesiacae is a good example of the observed transitional character of dry grassland vegetation in southeastern Bulgaria. Diagnostic species with high fidelity and constancy are considered also as diagnostic for 
Festuco-Brometea (Festuca valesiaca, Chondrillajuncea, Potentilla neglecta) or Koelerio-Corynephoretea (Trifolium arvense, Rumex acetosella). In this association, the representation of species typical for Festucion valesiacae is poor. On the other hand, there is a significant number of species with high constancy for the class Koelerio-Corynephoretea that differentiate the new association from Festuco valesiacae-Stipetum capillatae and MedicaginiFestucetum valesiacae.

Festuca valesiaca has broad distribution and naturally takes part in many different communities. The new association differs from the other known Festuca valesiaca communities described in the literature. Among the species with high constancy in the associations Galio-Festucetum valesiacae R. Jovanović 1956, Festucetum valesiacae Borisavljević 1955 and Trifolio-Festucetum valesiacae Diklić \& Nikolić 1972, only Festuca valesiaca is found in our data (Jovanović-Dunjić 1956, Borisavljević et al. 1955, Diklić \& Nikolić 1972). Constant species of these associations, such as Potentilla argentea, Teucrium chamaedrys, Hypericum perforatum, Lotus corniculatus and others, were not found in our communities. The above mentioned associations are rich in mesophilic species missing in our relevés, for example Fragaria vesca, Plantago media, Dactylis glomerata, Leucanthemum vulgare and Festuca pratensis.

Chrysopogon gryllus is a widely distributed species in Bulgaria and one of the main dominants in the herbaceous vegetation of lowland and lower mountain zones. Its communities are classified within Festucion valesiacae and Chrysopogono grylli-Danthonion calycinae (Tzonev 2002, Meshinev et al. 2005, Apostolova \& Meshinev 2006, Vassilev 2012). The associations Thymo pannonici-Chrysopogonetum grylli Doniță et al. 1992, Chrysopogono-Caricetum humilis (Soó 1930) Zólyomi 1958 and Dauco guttati-Chrysopogonetum grylli Popescu \& Sanda 1978, reported for Romania, are assigned to the alliance Festucion valesiacae (Sanda et al. 1997, Sanda et al. 1999). Chrysopogonetum grylli Soó 1939 (recently considered as a syntaxonomical synonym of Thymo pannonici-Chrysopogonetum grylli; Sanda et al. 1999) is known for the many geographically distinguished subassociations (e.g. oltenicum Buia et al. (1959) 1960; dobrogicum Dihoru 1970; moldavicum Bârcă 1975; campinensis Borza 1959; transsilvanicum Csűrös \& Niedermaier 1966; praemoesicum Roman 1974; banaticum Borza 1962) described by Romanian vegetation scientists.
Chrysopogon gryllus is considered as diagnostic for various syntaxonomical categories by Ilijanić \& Topić (1989), who have reviewed its communities in the territory of former Yugoslavia. According to Kojić et al. (1998), this species occurs in many associations within Festucion valesiacae (e.g. Trifolio montani-Chrysopogonetum grylli Veljović 1967, Chrysopogono-Festucetum valesiacae Veljović 1971, Bromo squarrosi-Chrysopogonetum grylli Kojić 1959), Festucion rupicolae (Chrysopogonetum pannonicum Stjepanović-Veseličić 1953, Chamaecytiso austriacae-Chrysopogonetum grylli Butorac 1989, Trifolio campestri-Chrysopogonetum grylli Butorac 1989, Thymo-Chrysopogonetum grylli Stojanović 1983, Inulo-Chrysopogonetum grylli Stevanović 1984) and Chrysopogono-Danthonion calycinae (AgrostidetoChrysopogonetum grylli Kojić 1959, Teucrio-Chrysopogonetum grylli R. Jovanović 1954, Koelerio gracilis-Chrysopogonetum grylli Vučković 1985 (Kojić et al. 1998) in Serbia.

Chrysopogon gryllus also has a diagnostic role also in Erysimo-Trifolietum Micevski 1977 and $\mathrm{He}^{-}$ lianthemo-Euphorbietum thessalae Micevski 1973 (Trifolion cherleri, Helianthemetea guttati) in Macedonia. It is a dominant species in Nardo-Callunetea-communities in continental parts of Western Croatia (Ilijanić et al. 1972).

Chrysopogon gryllus has a wide ecological plasticity and its distribution optimum is in the Balkans and Romania (Tzonev 2002). This is a reason why the species is referred to as diagnostic for various syntaxa. It also explains the different approaches for the classification of the communities hosting Chrysopogon gryllus, from describing one broad and heterogeneous association (Thymo pannonici-Chrysopogonetum grylli) in Romania on the one hand, and on the other hand its use by Serbian researchers to describe many geographically restricted associations that reflect differentiation in environmental characteristics. Our Chrysopogon gryllus-dominated communities have diagnostic species for Festucion valesiacae and Festuco-Brometea, which gave us reason to treat them as subordinated to these higher syntaxa. Significant heterogeneity of the sampled relevés did not allow the identification of a particular association.

Vegetation on calcareous stony terrains in the Straldzha-Aytos region is distinct from the above mentioned vegetation types and rather corresponds to the association Euphorbio myrsinitaeBothriochloetum. Comparison of species composition and constancy classes between stands of 
southeastern Bulgarian (Table 7, column A) and eastern Serbian associations (Table 7, column B, according Horvat et al. 1974) shows much similarity. However, the presence of the Bulgarian endemic Medicago rhodopaea, justifies the proposal of a new sub-association.

We established two plant associations within the Trifolion cherleri alliance, described in detail by Sopotlieva \& Apostolova (2007) and Sopotlieva (2009). The position of Trifolion cherleri in higher syntaxonomic units is still questionable (Sopotlieva \& Apostolova 2007, Ćušterevska et al. 2012) and probably will be solved by a large scale analyses of Balkan dry grasslands (K. Vassilev et al. in prep.).

The Koelerio-Corynephoretea class was registered in the study region for the first time in Bulgaria. Vulpietum myuri represents pioneer vegetation and was very rarely observed. Similar communities for Romania, Germany and Slovakia have been assigned to Filagini-Vulpietum Oberdorfer 1938 (Korneck 1993, Valachovič \& Maglocký 1995, Sanda et al. 1999). According to Valachovič \& Maglocký (1995) Vulpietum myuri is a synonym of this association, but we follow here the view of Sádlo et al. (2007). Recently, the vegetation of Thero-Airion was also found in Bulgaria (Pedashenko et al. 2013), which enlarges the area occupied by Koelerio-Corynephoretea vegetation.

\section{CONCLUSIONS}

Dry grasslands in the transitional zone between Continental and Mediterranean regions in southeastern Bulgaria were floristically distinguished in this study and classified within the two main classes of Festuco-Brometea and Helianthemetea guttati. Sharing the same territory, communities of these classes also share a lot of species, and have similar ratios of hemicryptophytes/therophytes and Euro-Asiatic/Mediterranean species. Both vegetation types occupy mostly shallow and dry soils. There is no significant difference between the associations in terms of soil properties such as $\mathrm{pH}$, humus content, soil moisture, etc.

Classification to certain vegetation types is rather complicated because of the gradual floristic and ecological differentiation between sampled communities. We identified associations known for Central Europe such as Bothriochloetum ischaemi, Festuco-valesiacae-Stipetum capillatae, Medicagini-Festucetum, but with the presence of more Mediterranean species and therophytes in the study area. Trifolio arvensis-Festucetum valesiacae is established as a new association distributed all over the study area, and probably with widespread occurence in the country.

Saturejion montanae should be considered as more widely distributed in Bulgaria than previously thought. It is confined to calcareous terrains with a lot of rock outcrops that allows for rich biodiversity and endemism. We defined the new subassociation medicaginetosum rhodopaeae as an endemic vegetation sub-type within the Balkan association Euphorbio myrsinitae-Bothriochloetum.

The class Koelerio-Corynephoretea has been sampled for the first time by Sopotlieva (2008), but recently new data were obtained (Pedashenko et al. 2013) that indicate the necessity of further research in the rest of the country.

According to our results, the vegetation at the boundary between the European and Mediterranean biogeographic regions represents widespread syntaxa from both zones. However, in the transitional area the diagnostic species for high rank syntaxa mix. It is highly probable that additional new vegetation types could be found in the study area. Research will be continued in this area to expand the knowledge about the vegetation in the contact zone of these two climate types.

\section{Acknowledgements}

This study was partly financially supported by the Bulgarian National Fund "Science Researches" by the grant DMU03 115/13. 12. 2011. We are grateful to the reviewers for their help to improve the earlier version of the manuscript, to Laura Sutcliffe (Göttingen) who did the linguistic editing and to editors Ioannis Tsiripidis and Jürgen Dengler for their valuable comments.

\section{REFERENGES}

Apostolova, I. \& Meshinev, T. 2006: Classification of semi-natural grassland in North-Eastern Bulgaria. Annali di Botanica, Nuova Serie 6: 29-52.

Apostolova, I., Sopotlieva, D., Pedashenko, H., Velev, N. \& Vasilev, K. 2012: Bulgarian vegetation database: historic background, current status and future prospects. Biodiversity \& Ecology 4: 141-148. 
Asenov, A. 2006: Biogeografia na Balgaria [Biogeography of Bulgaria]. An-Di Publishing, Sofia, 543 pp.

Assyov, B., Dimitrov, D., Vassilev, R. \& Petrova, A. 2002: Konspekt na visshata flora na Balgaria. Horologia i florni elementi [Conspectus of the Bulgarian vascular flora. Distribution maps and floristic elements]. BSBCP, Sofia, 424 pp.

Bondev, I. 2002: Geobotanichesko rajonirane [Geobotanic regioning]. In: Kopralev, I. (ed.): Geografia na Balgaria. Fizicheska i socialnoikonomicheska geografia [Geography of Bulgaria. Physical and socio-economic geography]. Publ. House ForCom, Sofia, pp. 336352. [in Bulgarian].

Borisavljević, L., Jovanović-Dunjić, R. \& Mišić, V. 1955: Vegetacija Avale [Vegetation auf der Avala]. Académie Serbe des Sciences, Institut d'écologie et de biogeography, Recueil des Travaux, 6(3): 3-43. [in Serbian, with German summary].

Braun-Blanquet, J. 1965: Plant sociology. The study of plant communities. Hafner Publishing Company, New York, 439 pp.

Bruelheide, H. 1995: Die Grünlandgesellschaften des Harzes und Standortsbedingungen mit einem Beitrag zum Gliederungsprinzip auf der Basis von statistisch ermittelten Artengruppen. Dissertationes Botanicae 244: 1-338.

Chytrý, M. (ed.) 2007: Vegetace České republiky1. Travinná a keříčková vegetace [Vegetation of the Czech Republik 1. Grassland and heathland vegetation.], Academia, Praha, 526 pp. [in Czech, with English summary].

Chytrý, M. \& Otýpková, Z. 2003: Plot sizes used for phytosociological sampling of European vegetation. Journal of Vegetation Science 14: 563-570.

Chytrý, M. \& Tichý, L. 2003: Diagnostic, constant and dominant species of vegetation classes and alliances of the Czech Republic: a statistical revision. Folia Facultatis Scientiarum Naturalium Universitatis Masarykianae Brunensis, Biologia, 108: 1-231.

Chytrý, M., Tichý, L., Holt, J. \& Botta-Dukát, Z. 2002: Determination of diagnostic species with statistical fidelity measures. Journal of Vegetation Science 13: 79-90.

Chytrý, M., Hoffmann, A. \& Novák, J. 2007: Suché trávniky [Dry grasslands]. In: Chytrý, M. (ed.): Vegetace České republiky1. Travinná a keříčková vegetace [Vegetation of the Czech
Republik 1. Grassland and heathland vegetation], Academia, Praha, pp. 371-470 [in Czech, with English summary].

Ćušterevska, R., Matevski, V., Kostadinovski, M. \& Čarni. A. 2012: Dry grassland communities of Erysimo-Trifolietum in the north-eastern part of the Republic of Macedonia. Hacquetia 11: 91-111.

Diklić, N. \& Nikolić, V. 1972: O nekim livadskim zajednicama iz Đerdapske klisure [Über einige Wiesengemeinschaften aus dem Defilee Djerdap]. Glasnik Prirodnajačog Muzeja Beograd, Serija B, 27: 201-212 [in Serbian, with German summary].

Donov, V., Gencheva, S. \& Yorova, K. 1974: Rakavodstvo za upraznenia po gorsko pochvoznanie [Manual for classwork of forest pedology]. Zemizdat, Sofia, 219 pp. [in Bulgarian].

Elíaš, P. jr., Sopotlieva, D., Dítě D., Hájková, P., Apostolova, I., Senko, D., Melečková, Z. \& Hájek, M. 2013: Vegetation diversity of saltrich grassland in Southeast Europe. Applied Vegetaion Science 16: 521-537.

Ganeva, A. \& Düll, R. 1999: A contribution to the Bulgarian bryoflora. Checklist of the Bulgarian bryophytes. In: Düll, R., Ganeva, A., Martinčič, A. \& Pavletić, Z. (eds.): Contributions to the bryoflora of former Yugoslavia and Bulgaria. IDH-Verlag, Bad Münstereifel, pp. 111-199.

Gruev, B. \& Kuzmanov, B. 1994: Obshta biogeografia [General biogeography]. University Press "St. Kliment Ohridski", Sofia, 498 pp. [in Bulgarian].

Hennekens, S. M. \& Schaminée, J. H. J. 2001: TURBOVEG, a comprehensive data base management system for vegetation data. Journal of Vegetation Science 12: 589-591.

Horvat, I. 1962: Vegetacija planina Zapadne Hrvatske sa 4 karte biljnih zajedca sekcije Sušak. [Aperçu de la vegetation de la Croatie d'Ouest]. Acta Biologica II, Prirodoslovna Istraživanja, Jugoslavenska Akademija Znanosti i Umjestnosti, Zagreb knjiga, 30: 1-179 [in Croatian, with French summary].

Horvat, I., Glavač, V. \& Ellenberg, H. 1974: Vegetation Südosteuropas. Gustav Fischer Verlag, Jena, 767 pp.

Horvatić, S. 1963: Vegetacijska karta otoka paga s općim pregledom vegetacijskih jedinica $\mathrm{Hr}$ vatskog primorja. [Carte des groupements végétaux de l'île Nord-Adriatique de Pag avec un aperçu general des unites végétales du lit- 
toral Croate]. Acta Biologica IV, Prirodoslovna Istraživanja, Jugoslavenska Akademija Znanosti i Umjestnosti, Zagreb knjiga 33: 1-187 [in Serbian, with French summary]

Horvatić, S. 1975: Neuer Beitrag zur Kenntnis der Syntaxonomie der Trockenrasen- und Steintriften-Gesellschaften des Ostadriatischen Karstgebietes. In: Jordanov, D. (ed.): Problems of Balkan flora and vegetation. Publishing house Bulgarian Academy of Sciences, Sofia, pp. 300-310.

Ilijanić, L., Gaži, V. \& Topić, J. 1972: Grasslands containing Chrysopogon gryllus in continental regions of West Croatia. Acta Botanica Croatica 31: 155-164.

Ilijanić, L. \& Topić, J. 1989: On the sociology of Chrysopogon gryllus in Yugoslavia. Acta Botanica Croatica 48: 75-82.

ISO 10390. 1994: Soil quality - Determination of $\mathrm{pH}$.

ISO 11464. 1994: Soil quality - Pretreatment of samples for physico-chemical analyses.

Jovanović-Dunjić, R. 1955: Tipovi pašnjaka i livada Suve planine [Wieden- und Wiesentypen der Suva Planina]. Académie Serbe des Sciences, Institut d'écologie et de biogeography, Recueil des travaux 6(2): 104 pp., Beograd [in Serbian, with German summary].

Klika, J. 1931: Studien über die xerotherme Vegetation Mitteleuropas I. Die Pollauer Berge im südlichen Mähren. Beihefte zum Botanischen Centralblatt, Abt. II, 47: 343-398.

Klika, J. 1933: Studien über die xerotherme Vegetation Mitteleuropas II. Xerotherme Gesellschaften in Böhmen. Beihefte zum Botanischen Centralblatt, Abt. II, 50: 707-773.

Klika, J. 1934: Studien über die xerotherme Vegetation Mitteleuropas III. Die Pflanzengesellschaften auf Sandböden des Marchfeldes in der Slowakei. Beihefte zum Botanischen Centralblatt, Abt. B, 52(1): 1-16.

Klika, J. 1936: Studien über die xerotherme Vegetation Mitteleuropas IV. Erläuterung zur vegetationkundlichen Karte des Lovoš (Lobosch). Beihefte zum Botanischen Centralblatt, Abt. B, 54(3): 489-515.

Klika, J. 1939: Die Gesellschaften des Festucion vallesiacae-Verbandes in Mitteleuropa. Studia Botanica Čechica 2(3): 117-157.

Kojić, M., Popović, R. \& Karadžić, B. 1997: Vaskularne biljke Srbije kao indikatori staništa. Institut za istraživanja u poljoprivredi "Srbila" [Vascular plants of Serbia as indi- cator species for plant communities]. Institut za biološka iztraživanja "Siniša Stanković", Beograd, 160 pp. [in Serbian, with English summary].

Kojić, M., Popović, R. \& Karadžić, B. 1998: Sintaksonomski pregled vegetacije Srbije. [A syntaxonomic review of vegetation in Serbia]. Institut za biološka istraživanja "Siniša Stanković", Beograd, 218 pp. [in Serbian, with English summary].

Kononova, M. M. 1966: Soil organic matter. Its nature, its role in soil formation. $2^{\text {nd }}$ ed. Pergamon, New York, 544 pp.

Korneck, D. 1993: Klasse: Sedo-Scleranthetea Br.Bl. 55 em. Th. Müller 61. In: Oberdorfer, E. (ed.): Süddeutsche Pflanzengesellschaften. Teil II. Sand- und Trockenrasen, Heide- und Borstgrasgesellschaften, alpine Magerrasen, Saum-Gesellschaften, Schlag- und Hochstauden-Fluren. 3rd ed. Gustav Fischer Verlag, Jena, pp. 13-85.

Kozhuharov, S. 1992 (ed.): Opredelitel na visshite rastenia $\mathrm{v}$ Balgaria [Field guide to the vascular plants in Bulgaria]. Naouka \& Izkoustvo, Sofia, 788 pp. [in Bulgarian].

Meshinev, T., Apostolova, I., Georgiev, V., Dimitrov, V., Petrova, A. \& Veen, P. 2005: Grasslands of Bulgaria. Final report on the National Grasslands Inventory Project. Bulgaria, 20012004. Dragon 2003 Ltd. Publishers, Sofia, $104 \mathrm{pp}$

Micevski, K. 1970: Astragalo-Potentilletalia, nov vegetaciski red na brdskite pasishta vo Makedonija [Astragalo-Potentilletalia, eine neue Vegetationsordnung der Bergweiden Mazedoniens]. Contributions, 2-Section for Natural sciences and Mathematics, Macedonian Academy of Sciences and Arts, Skopje, 2: 15-23 [in Macedonian, with German summary].

Micevski, K. 1977: Erysimo-Trifolietum Micev. ass. nov. vo vegetacijata na Makedonija [ErysimoTrifolietum Micev. ass. nov. in der Vegetation Makedoniens]. Contributions, 1-Section for Natural sciences and Mathematics, Macedonian Academy of Sciences and Arts 9: 76-82 [in Macedonian, with German summary].

Micevski, K. 1978: Tipološki ispituvanja na vegetatcijata na livadite i pasištata vo Maleš i Pijanec [Typologishe Untersuhungen der Wiesen- und Weiden-Vegetation der gebiete Maleš und Pijanec]. Maleš and Pijanec I, pp. 9-41. [in Macedonian, with German summary]. 
Mucina, L. 1997: Conspectus of classes of European vegetation. Folia Geobotanica et Phytotaxonomica 32: 117-172.

Natcheva, R. \& Ganeva, A. 2005: Check-list of the bryophytes of Bulgaria with data on their distribution. II. Musci. Cryptogram Bryology 26: 209-232.

Ninov, N. 2002: Taksonomia i klasifikacionna sistema na pochvite [Taxonomy and classification system of the soils]. In: Kopralev, I. (ed.): Geografia na Balgaria. Fizicheska i socialnoikonomicheska geografia [Geography of Bulgaria. Physical and socio-economic geography]. Publ. House ForKom, Sofia, pp. 284298 [in Bulgarian].

Oberdorfer, E. 1993 (ed.): Süddeutsche Pflanzengesellschaften. Teil II. Sand- und Trockenrasen, Heide- und Borstgrasgesellschaften, alpine Magerrasen, Saum-Gesellschaften, Schlagund Hochstauden-Fluren. 3rd ed. Gustav Fischer Verlag, Jena, 355 pp.

Pedashenko, H. Apostolova, I., Boch, S., Ganeva, A., Janišová, M., Sopotlieva, D., Todorova, S., Ünal, A., Vassilev, K., Velev, N. \& Dengler, J. 2013: Dry grasslands on NW Bulgarian mountains: first insights into diversity, ecology and syntaxonomy. Tuexenia 33: 309-346.

Pop, I. 1968: Flora şi vegetația Cîmpiei Crişurilor [Flora and vegetation of Campia Crisurilor]. Editura Academiei Republicii Socialiste România, 280 pp. [in Romanian].

Pop, I. 1977: Studiu comparative asupra pajuştilor de Bothriochloa ischaemum din Romania [A comparitive study on the lawns of Botriochloa ischaemum from Romania]. Contributii Botanice, Cluj-Napoca, pp. 111-120. [in Romanian, with English summary].

Pop, I., Cristea, V. \& Hodişan, I. 2002: Vegetația județului Cluj (Studiu fitocenologic, ecologic, bioeconomic şi eco-protectiv) [The vegetation of Cluj District (a phytocoenological, ecological, bioconomic and ecoprotective study]. - Contribuții Botanice, Cluj-Napoca 35(2): 5-254 [in Romanian, with English summary].

Quinn, G. P. \& Keough, M. J. 2002: Experimental design and data analysis for biologists. Cambridge University Press, Cambridge, XVII + $537 \mathrm{pp}$.

Rivas-Martínez, S., Fernández-Gonzáles, F., Loidi, J., Lousã, M. \& Penas, A. 2001: Syntaxonomical checklist of vascular plant communities of Spain and Portugal to association level. Itinera Geobotanica, 14: 5-341.
Rivaz-Martínez, S., Penas, A. \& Díaz, T. E. 2004: Biogeographic map of Europe. Cartographic Service. University of León, León.

Rodwell, J. S., Schaminée, J. H. J., Mucina, L., Pignatti, S., Dring, J. \& Moss, D. 2002: The Diversity of European Vegetation. An overview of phytosociological alliances and their relationships to EUNIS habitats. EC-LNV, 2002(054), National Reference Centre for Agriculture, Nature and Fisheries, Wageningen, $168 \mathrm{pp}$.

Roman, N. 1974: Flora şi vegetaţia din sudul podişului Mehedinți [The flora and vegetation of the south of the Mehedinti tableland]. Editura Academiei Republicii Socialiste România, Bucureşti, 22 pp. [in Romanian with English summary].

Royer, J.-M. 1991: Synthese eurosibérienne, phytosociologique et phytogéographique de la classe des Festuco-Brometea. Dissertationes Botanicae, 178: 1-296.

Sádlo, J., Chytrý, M. \& Černý, T. 2007: Pionýrská vegetace písčin a mělkých půd (KoelerioCorynephoretea) [Pioneer vegetation of sandy and shallow soils]. In: Chytrý, M. (ed.): Vegetace České republiky1. Travinná a keříčková vegetace [Vegetation of the Czech Republic 1. Grassland and heathland vegetation]. Academia, Praha, pp. 320-365. [in Czech, with English summary].

Sanda, V., Popescu, A. \& Arcus, M. 1999: Revizia critică a comunităților de plante din România [Critical revision of plant communities of Romania]. Editura "Tilia Press international", Constanța, pp. 97. (in Romanian)

Sanda, V., Popescu, A. \& Barabaş, N. 1997: Cenotaxonomia şi caracterizarea grupărilor vegetale din România [Syntaxonomy and characteristics of vegetation types of Romania]. Studii şi comunicări, Biologie vegetală, Bacău, România, 366 pp. [in Romanian].

Solomakha, V. A. 1996 (ed.): Sintaksonomia roslinosti Ukraini [Syntaxonomy of vegetation of Ukraine]. Український фітоценологічний збірник, Серія A, 4(5): 1-121 [in Ukrainian].

Sopotlieva, D. 2008: Sintaksonomichna harakteristika na trevnata rastitelnost $\mathrm{v}$ StraldzhanskoAjtoski geobotanichen okrag [Syntaxonomical characteristic of grassland vegetation in Straldzha-Aytos phytogeographic region]. PhD thesis, Institute of Botany, Bulgarian Academy of Sciences, Sofia, 148 pp. [in Bulgarian]. 
Sopotlieva, D. 2009: Poo bulbosae-Achileetum pseudopectinatae: a new plant association. Phytologia Balkanica 15: 235-244.

Sopotlieva, D. \& Apostolova, I. 2007: The association Erysimo-Trifolietum Micev. 1977 in Bulgaria and some remarks on its Mediterranean character. Hacquetia 6: 131-141.

StatSoft Inc. 2009: STATISTICA 9. Data analysis software. StatSoft, Tulsa.

Takhtajan, A. L. 1986: Floristic regions of the world. University of California Press, Berkeley, $544 \mathrm{pp}$.

Tichý, L. 2005: New similarity indices for the assignment of relevés to the vegetation units of an existing phytosociological classification. Plant Ecology 179: 67-72.

Tichý, L. \& Chytrý, M. 2006: Statistical determination of diagnostic species for site groups of unequal size. Journal of Vegetation Sciences 17: 809-818.

Tzonev, R. 2002: Flora i rastitelnost na sredna Dunavska ravnina mezdu rekite Vit i Stidena [Flora and vegetation of middle Danube plain between valleys of rivers Vit and Studena]. PhD thesis in Botany, University of Sofia "St. Kliment Ohridski, Sofia, 166 pp. [in Bulgarian].
Tzonev, R., Lysenko, T., Gussev, C. \& Zhelev, P. 2008: The halophytic vegetation in south-east Bulgaria and along the Black sea coast. Hacquetia 7: 95-121.

Valachovič, M. \& Maglocký, Š. 1995: Sedo-Scleranthetea. In: Valachovič, M. (ed.): Rastlinné spoločenstvá Slovenska. 1. Pionierska vegetácia [Plant communities of Slovak Republic. 1. Pioneer vegetation]. Veda, Bratislava, pp. 85106. [in Slovak].

Vassilev, K. 2012: Trevna rastitelnost po varoviti tereni zapadno ot Sofiya [Grassland vegetation on calcareous terrains west of Sofia]. PhD thesis, Institute of Biodiversity and Ecosystem Research, Sofia, 185 pp. [in Bulgarian].

Velev, S. 2002: Klimatichno rajonirane [Climatic zoning]. In: Kopralev, I. (ed.): Geografia na Balgaria. Fizicheska i socialno-ikonomicheska geografia [Geography of Bulgaria. Physical and socio-economic geography]. Publ. House ForKom, Sofia, pp. 155-156 [in Bulgarian].

Westhoff, V. \& van der Maarel, E. 1980: The Braun-Blanquet Approach. In: Whittaker, R.H. (ed.): Classification of plant communties. Junk, The Hague, pp. 289-399.

Received 7.7.2013

Accepted 10.1.2014

Co-ordinating editor: Ioannis Tsiripidis 
Table 1: Shortened synoptic table of studied plant communities.

Tabela 1: Skrajšana sinoptična tabela proučevanih rastlinskih združb.

\begin{tabular}{|c|c|c|c|}
\hline \multicolumn{2}{|c|}{ A } & B & C \\
\hline a & b & c & d \\
\hline
\end{tabular}

Number of relevés

$\begin{array}{lllllllll}81 & 11 & 12 & 11 & 11 & 22 & 18 & 7 & 3\end{array}$

\section{Cl. Festuco-Brometea}

Petrorhagia prolifera

Thymus striatus

Eryngium campestre

Chondrilla juncea

Dichantium ischaemum

Astragalus onobrychis

Asperula cynanchica

Chrysopogon gryllus

Achillea setacea

Centaurea rhenana

Convolvulus cantabrica

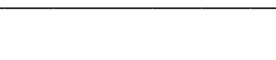

11

$\begin{array}{rrrrrrrrr}54 & 36 & 58 & 73 & 27 & 9 & 39 & 71 & 33 \\ 62 & 82 & 100 & 91 & 45 & 68 & 67 & 100 & 33 \\ 94 & 82 & 100 & 73 & 100 & 32 & 89 & 43 & 67 \\ 31 & 27 & 33 & 73 & 9 & 23 & 50 & 29 & 33 \\ 100^{* *} & 73 & 58 & 18 & 18 & 64 & 39 & 43 & 33 \\ 21 & 18 & 58 & 27 & 36 & 23 & 11 & 71 & . \\ 31 & 45 & 58 & 45 & 27 & 59 & 22 & . & . \\ 7 & 27 & 25 & 45 & 100^{* *} & 73 & 33 & . & . \\ 38 & 18 & 42 & 45 & 64 & 9 & . & 14 & . \\ 10 & 18 & . & 9 & 9 & 23 & 22 & 14 & . \\ 6 & 27 & . & 9 & 18 & 45 & 22 & 29 & .\end{array}$

All. Festucion valesiacae

Festuca valesiaca

Stipa capillata

Linaria genistifolia

Teucrium chamaedrys

$\begin{array}{rcrrrrrr}40 & 55 & 100 & 100 & 64 & 59 & 50 & 57 \\ 2 & 100^{* *} & 17 & 9 & 9 & 18 & 6 & 14 \\ 4 & 36 & . & 18 & 9 & 5 & 11 & 29 \\ 10 & 9 & 33 & 18 & . & 14 & 6 & .\end{array}$

Ass. Bothriochloetum ischaemi

Rumex pulcher

$20 * *$

9

Ass. Festuco valesiacae-Stipetum capillatae

Melica transsilvanica

Alyssum alyssoides

Ass. Medicagini-Festucetum valesiacae

Medicago falcata

$\begin{array}{llll} & 27^{* *} & & \\ & 27^{* *} & 8 & 9\end{array}$

$4.58 * * .9$

Ass. Trifolio arvensis-Festucetum valesiacae

Odontites serotina

Carex praecox

Potentilla neglecta

Elymus hispidus

Herniaria hirsuta

$\begin{array}{rrrl}1 & . & . & 27 * * \\ 12 & . & . & 36 * * \\ 25 & 18 & 25 & 73 * * \\ 5 & 27 & . & 36 * * \\ 33 & 55 & 50 & 73 * *\end{array}$

Chrysopogon gryllus-community

Nonea pulla

Galium verum

$17 \quad 18$

$\begin{array}{rrr}50 & 18 * * \\ 54 & 73^{* *}\end{array}$

$14 \quad 28$

29

All. Saturejion montana

Anthylis vulneraria

Leontodon crispus

Melica ciliata

Rhodax canus

Achillea clypeolata

Allium flavum

Satureja montana

Ass. Euphorbio myrsinitae-Bothriochloetum subass. medicaginetosum rhodopeae

Grimmia pulvinata

Echinops ritro

Paronychia cephalotes

Medicago rhodopaea 


\begin{tabular}{|c|c|c|c|c|c|c|c|c|c|}
\hline Number of relevés & 81 & 11 & 12 & 11 & 11 & 22 & 18 & 7 & 3 \\
\hline Weissia wimmeriana & & 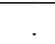 & . & . & . & $41 * *$ & . & . & . \\
\hline Sedum acre & 5 & 27 & 8 & . & . & $77 * *$ & 6 & 14 & . \\
\hline Ajuga chamaepytis & 4 & . & . & . & . & $41 * *$ & . & . & . \\
\hline Inula aschersoniana & . & . & . & . & . & $36^{* *}$ & . & . & . \\
\hline Crupina vulgaris & 1 & . & . & . & . & $32 * *$ & . & . & . \\
\hline Didymodon acutus & . & . & . & . & . & $27 * *$ & . & . & . \\
\hline Agropyron cristatum & . & . & . & . & . & $27 * *$ & . & . & . \\
\hline Hippocrepis ciliata & . & . & . & . & . & $27 * *$ & . & . & . \\
\hline Jurinea consanguinea & . & . & . & . & . & $27 * *$ & . & . & . \\
\hline Helianthemum salicifolium & 7 & 9 & 17 & 18 & . & $64 * *$ & . & 29 & . \\
\hline Linum tenuifolium & . & . & . & . & . & $23 * *$ & . & . & . \\
\hline Pleurochaete squarrosa & . & . & . & . & . & $23 * *$ & . & . & . \\
\hline Fumana procumbens & . & 9 & . & . & 9 & $36 * *$ & . & . & . \\
\hline Teucrium polium & 20 & 36 & 50 & 36 & 18 & $95 * *$ & 33 & 57 & . \\
\hline Centaurea ovina subsp. besserana & . & . & . & . & . & $18 * *$ & . & . & . \\
\hline Koeleria penzesii & . & . & . & . & . & $18 * *$ & . & . & . \\
\hline Euphorbia myrsinites & 17 & 27 & 33 & . & . & $68 * *$ & 11 & 43 & . \\
\hline Paliurus spina-christi & 1 & . & . & . & 9 & $23 * *$ & . & . & . \\
\hline Koeleria brevis & . & . & . & . & . & $14 * *$ & . & . & . \\
\hline Hypericum rumeliacum & 4 & 9 & 8 & . & 9 & $41 * *$ & 17 & 14 & . \\
\hline \multicolumn{10}{|l|}{ Cl. Helianthemetea guttati } \\
\hline Arenaria leptoclados* & 43 & 36 & 17 & 64 & . & 32 & 33 & 29 & 33 \\
\hline Trifolium campestre* & 31 & 18 & 33 & 55 & 36 & . & $89 * *$ & 14 & . \\
\hline Trifolium scabrum* & 28 & 18 & 50 & 36 & 18 & 18 & 22 & 43 & . \\
\hline Psilurus incurvus & 11 & 18 & 17 & . & . & 18 & $61 * *$ & . & 33 \\
\hline Trachynia distachya & 6 & 9 & 17 & . & . & 14 & . & . & . \\
\hline Arenaria serpyllifolia* & 7 & . & . & . & . & . & 6 & . & . \\
\hline Cynosurus echinatus & 9 & . & . & . & 9 & . & 11 & . & 33 \\
\hline Aira elegantissima* & . & . & . & . & . & . & $28 * *$ & . & . \\
\hline \multicolumn{10}{|l|}{ All. Trifolion cherleri } \\
\hline Taeniatherum caput-medusae & 64 & 27 & 25 & 45 & 45 & 9 & 28 & 29 & 67 \\
\hline Trifolium angustifolium & 17 & 9 & 17 & 18 & 27 & . & $61 * *$ & . & 33 \\
\hline Erysimum diffusum & 1 & 9 & 8 & 9 & . & 23 & 28 & 14 & . \\
\hline Trifolium arvense* & 14 & 36 & 8 & 73 & 9 & . & $78 * *$ & $86^{* *}$ & . \\
\hline Rumex acetosella & 2 & . & . & 36 & 27 & . & $61 * *$ & . & 33 \\
\hline Trifolium cherleri & 1 & 18 & . & . & . & 5 & 28 & 29 & . \\
\hline Trifolium striatum & 19 & . & 8 & 27 & 36 & . & 28 & . & 33 \\
\hline Vulpia ciliata & . & . & . & . & 9 & . & $28 * *$ & . & . \\
\hline Logfia minima & . & . & . & . & . & . & $33 * *$ & 14 & . \\
\hline Linaria pelisseriana & . & . & . & . & . & . & $22 * *$ & . & . \\
\hline Sedum caespitosum & . & . & 8 & . & . & . & 6 & . & . \\
\hline
\end{tabular}

\section{Ass. Erysimo diffusi-Trifolietum angustifoli}

Lotus angustissimus

Stachys angustifolia

Jasione heldreichii

Trifolium strictum

Hieracium praealtum

Sanguisorba minor

Brachythecium albicans

Achillea crithmifolia

Agrostis canina

Vicia grandiflora

Euphorbia cyparissias

Dianthus pinifolius

Hieracium hoppeanum

Koeleria macrantha 


\begin{tabular}{|c|c|c|c|c|c|c|c|c|c|}
\hline Number of relevés & 81 & 11 & 12 & 11 & 11 & 22 & 18 & 7 & 3 \\
\hline Verbascum adrianopolitanum & . & . & . & . & . & . & $11 * *$ & . & . \\
\hline Centaurium erythraea & . & . & . & . & . & . & $11 * *$ & . & . \\
\hline Gypsophila muralis & . & . & . & . & . & . & $11 * *$ & . & . \\
\hline Trifolium diffusum & . & . & . & . & . & . & $11^{* *}$ & . & . \\
\hline Verbascum thapsiforme & . & . & . & . & . & . & $11 * *$ & . & . \\
\hline Euphrasia stricta & . & . & . & . & . & . & $11 * *$ & . & . \\
\hline
\end{tabular}

Ass. Poo bulbosae-Achilletum pseudopectinatae

Achillea depressa

Koeleria simonkaii

Medicago rigidula

\section{Cl. Koelerio-Corynephoretea}

Poa bulbosa*

Medicago minima

Syntrichia ruralis

Ceratodon purpureus

Centaurea diffusa

Anthemis ruthenica

Bombycilaena erecta

Apera spica-venti

Acinos arvensis

Scleranthus annuus

Sideritis montana

Sedum acre

Cerastium pumilum

Filago lutescens

\section{All. Thero-Airion}

Scleranthus perennis

Dasypyrum villosum

Potentilla argentea

Filago vulgaris

\section{Ass. Vulpietum myuri}

Vulpia myurus

\section{Other species (occuring $>7$ syntaxa)}

Plantago lanceolata

Bromus squarrosus

Crepis setosa

Potentilla inclinata

Koeleria nitidula

Xeranthemum annuum

Erodium cicutarium

Veronica arvensis

Galium tenuissimum

Aegilops triuncialis

Centaurea caliacrae

Carduus nutans

Bromus tectorum

Erodium cicutarium

$\begin{array}{rrrrrrrrr}. & 18 & . & . & . & . & . & 100^{* *} & . \\ 2 & 9 & . & . & . & 5 & . & 43 * * & . \\ 30 & 27 & 33 & 18 & . & . & . & 71 * * & .\end{array}$

$\begin{array}{rrrrrrrrr}57 & 64 & 75 & 64 & 36 & 77 & 78 & 100 & 67 \\ 43 & 36 & 83 * * & 18 & 18 & 50 & 22 & 14 & . \\ 12 & 27 & 25 & 9 & 9 & 55 & 28 & 29 & . \\ 7 & 27 & 8 & 18 & 9 & 5 & 39 & 71 * * & . \\ 33 & 27 & 50 & 18 & 9 & . & 11 & 43 & 33 \\ 21 & 18 & 8 & 18 & . & . & 61 * * & 57 & . \\ 17 & 9 & 33 & . & . & 50^{* *} & 28 & . & . \\ 7 & 9 & . & 18 & 9 & . & . & 14 & 67 \\ . & 9 & . & . & . & 32^{* *} & 6 & . & . \\ 2 & . & 8 & . & . & 50^{* *} & . & . & . \\ 1 & 18 & . & . & . & 73^{* *} & 11 & 14 & . \\ 5 & 27 & 8 & . & . & 77^{* *} & 6 & 14 & . \\ 20 & . & . & 45 & 27 & 9 & 17 & . & . \\ 7 & 18 & . & 9 & . & . & 6 & 14 & .\end{array}$

$\begin{array}{rrrrrrrrr}11 & 27 & 8 & 27 & 9 & . & 44 & 71^{* *} & 33 \\ 27 & 18 & 25 & 18 & 18 & . & 11 & 14 & 33 \\ 5 & . & . & 18 & 27 & . & 33 & . & 33 \\ 17 & 9 & . & 9 & 18 & . & 22 & . & 33\end{array}$

\begin{tabular}{rrrrrrrrr}
21 & 18 & 8 & 9 & 9 & 5 & 39 & 14 & $100^{* *}$ \\
& & & & & & & & \\
65 & 9 & 58 & 73 & 45 & 9 & 61 & 29 & 33 \\
27 & 36 & 42 & 27 & 9 & 45 & 39 & 29 & 33 \\
59 & 36 & 50 & 45 & 64 & 32 & 50 & 57 & 100 \\
23 & 18 & 42 & 27 & 36 & 36 & 28 & 14 &. \\
6 & 36 & 8 & 45 & 27 & 50 & 50 & 14 &. \\
12 & 45 & 8 & 9 & 9 & 27 & 11 & 29 &. \\
12 & 9 & 25 & 27 & 9 &. & 22 & 14 &. \\
33 & 36 & 17 & 9 & 9 & 5 & 17 & 14 &. \\
20 & 9 & 17 & 36 & 18 & 5 & 28 & 43 &. \\
23 &. & 25 & 9 & 27 & 9 & 6 & 14 & 33 \\
6 & 9 & 33 & 9 & 9 & 5 &. & 43 & 33 \\
15 &. & 25 & 18 & 27 & 9 & 6 &. & 33 \\
4 & 27 & 8 & 9 & 9 &. & 11 & 14 &. \\
12 & 9 & 25 & 27 & 9 &. & 22 & 14 &. \\
\hline
\end{tabular}

Percentage constancies are given. Superscript symbol $\left({ }^{* *}\right)$ present phi-values above 0.30 (only species with a statistically significant affinity to a cluster according to Fisher's exact test with $P<0.01$ are included). Species affiliation to alliances and classes follow literature (see text). Superscript symbol $\left(^{*}\right)$ shows species considered as diagnostic for both Helianthemetea guttati and Koelerio-Corynephoretea. On the association level species are arranged according decreasing phi-values.

Main groups: A - class Festuco-Brometea; B - class Helianthemetea guttati; C - class Koelerio-Corynephoretea subgroups: a - alliance Festucion valesiacae; b - alliance Saturejion montanae; c - alliance Trifolion cherleri; $\mathrm{d}$ - alliance TheroAirion 
Table 2: Relevés of the association Bothriochloetum ischaemi (Krist. 1937) I. Pop 1977.

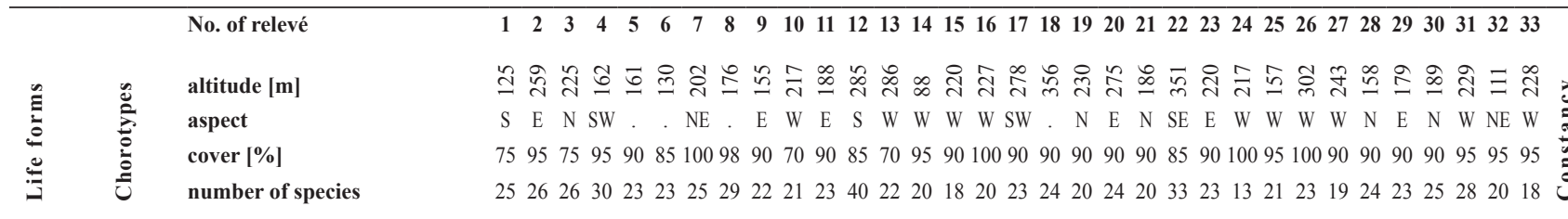

typicum

Character species for the association

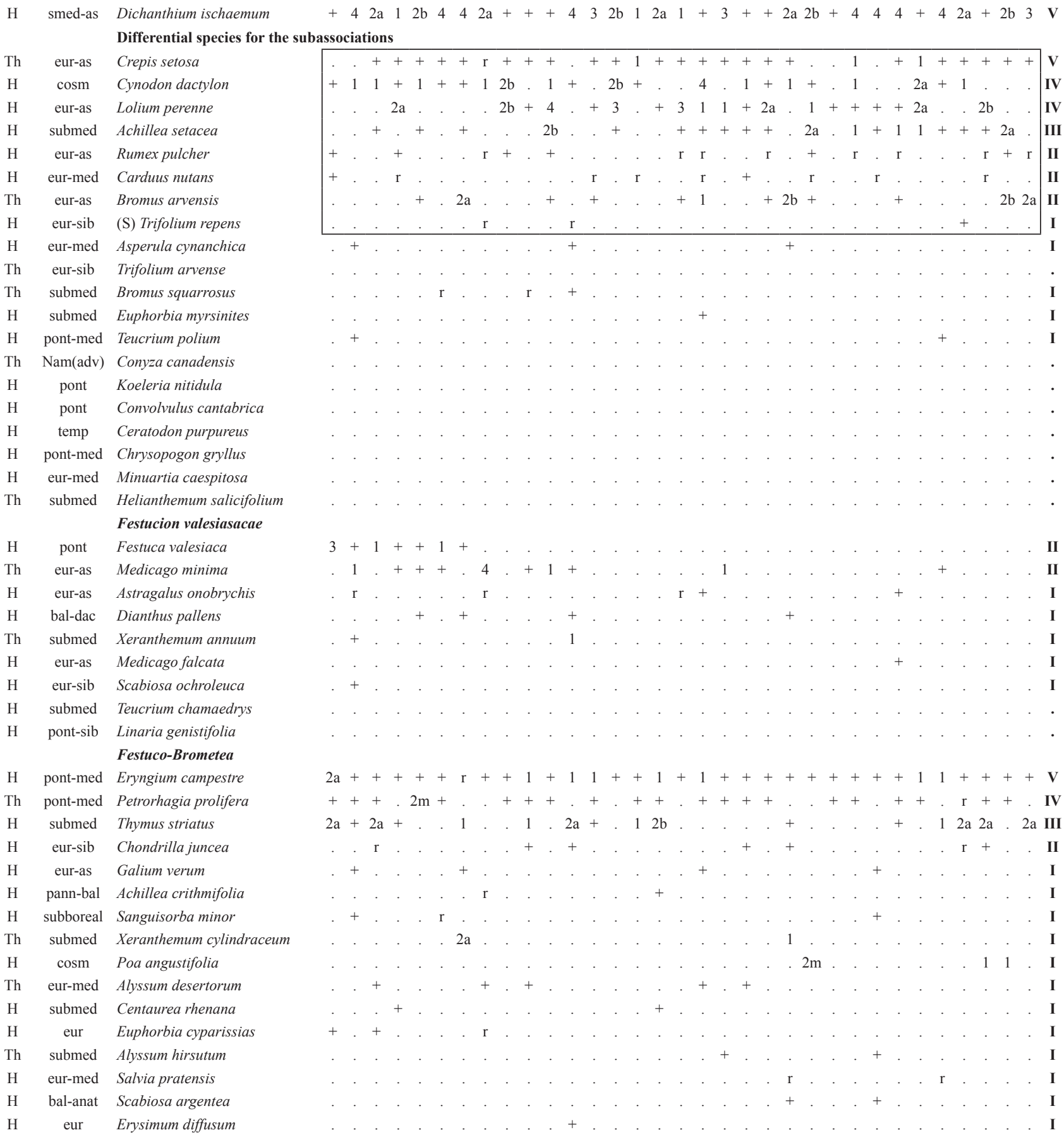


Tabela 2: Popisi asociacije Bothriochloetum ischaemi (Krist. 1937) I. Pop 1977.

$343536373839404142434445464748495051525354555657585960616263646566 \quad 676869707172737475767778798081$

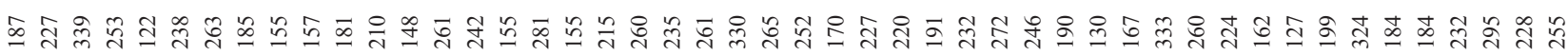

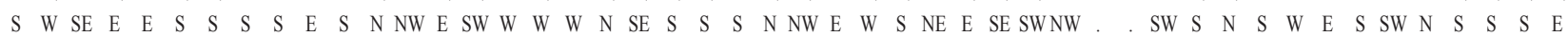

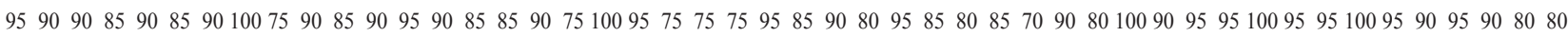

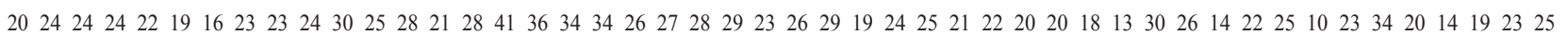

$42 \mathrm{a}++442 \mathrm{a} 2 \mathrm{~m} 2 \mathrm{~b} 2 \mathrm{~b} 2 \mathrm{a} 2 \mathrm{a}+\begin{array}{lllllllllllllllllllllllllllllllll} & 4 & 3 & 3 & 3 & 2 \mathrm{~b} & 1 & 2 \mathrm{a} & 2 \mathrm{~b} & 2 \mathrm{a} & \mathrm{r} & \mathrm{r} & 4 & 3 & 3 & 2 \mathrm{a} & \mathrm{r} & 3 & 2 \mathrm{a}+ & + & 5 & 4 & 2 \mathrm{a} & 3 & 5 & 5 & 5 & 5 & 4 & 4 & \mathbf{V}\end{array}$

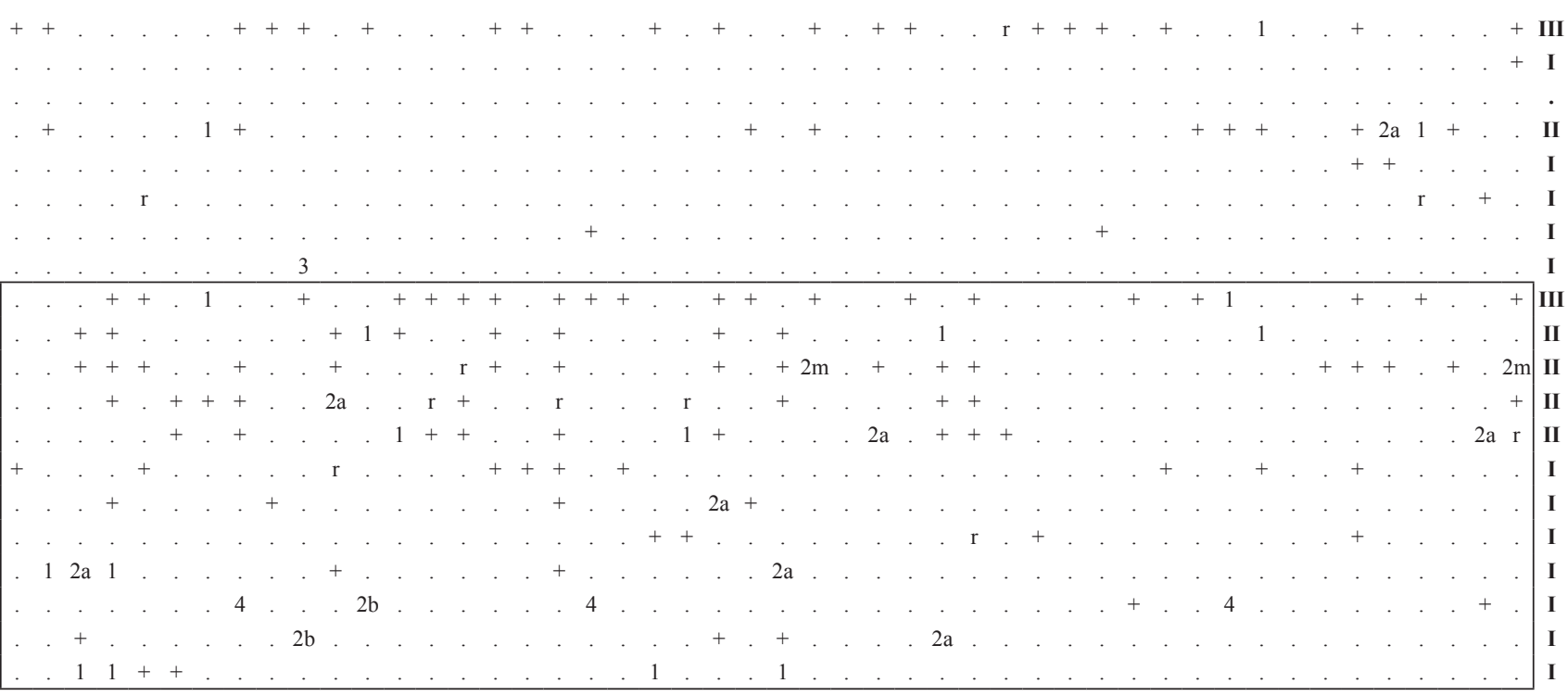

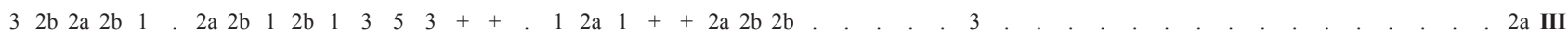

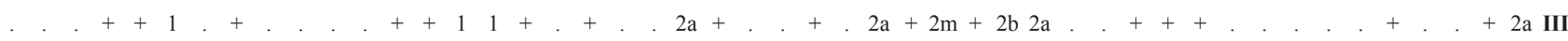

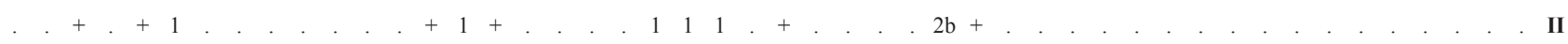

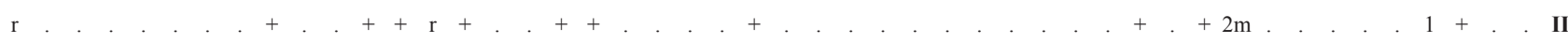

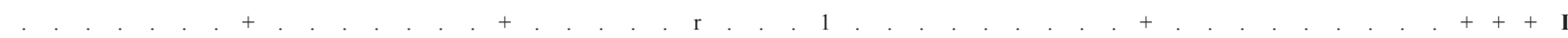

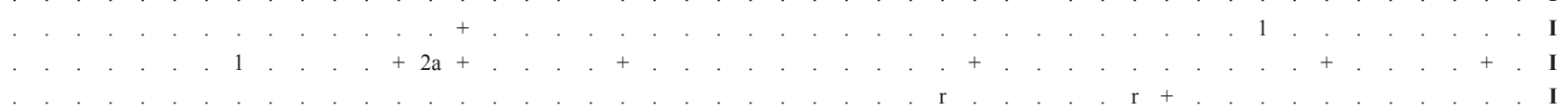

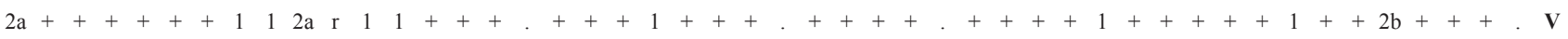

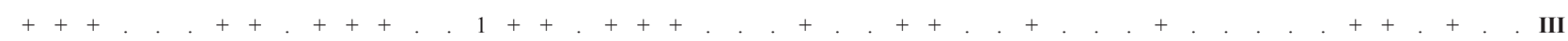

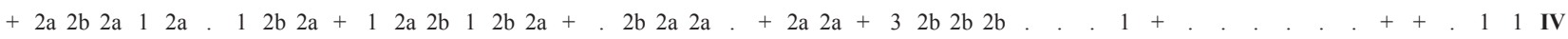

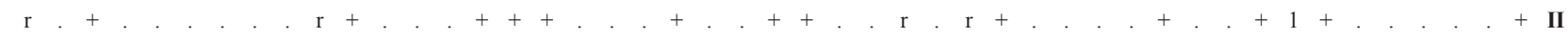

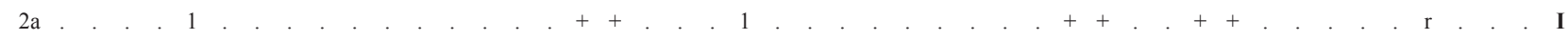

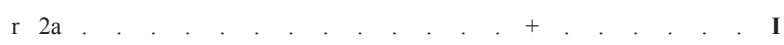

$2 \mathrm{a}$ 
No. of relevé

\begin{tabular}{|c|c|c|c|c|c|c|c|c|c|c|c|c|c|c|c|c|c|c|c|c|c|c|c|c|c|c|c|c|c|c|c|}
\hline $\mathrm{H}$ & eur-sib & Knautia arvensis & & & . & & . & . & . & & . & & $\cdot$ & - & 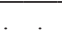 & . & & . & & . + & ++ & & . & . & . & + & + . & . & & . & I \\
\hline \multirow[t]{2}{*}{$\mathrm{H}$} & eur-med & Artemisia santonicum s. patens & & . & . & . & . & . & . & . & . & . & . & . & . & . & . & . & . & . & . & . & . & . & . & . . & . . & . & $\cdot$ & . & • \\
\hline & & Koelerio-Corynephoretea & & & & & & & & & & & & & & & & & & & & & & & & & & & & & \\
\hline $\mathrm{H}$ & eur-as & Poa bulbosa & $2 b$ & 12 & $2 b$ & +3 & 31 & .2 & $2 b$ & 3 & 3 & . & . 1 & 1. & . $2 \mathrm{a}$ & + & $2 \mathrm{a}$ & . 2 & $2 \mathrm{~b}$ & 4. & . + & $2 \mathrm{a}$ & 1 & . & . & $2 \mathrm{a}$. & . & . $2 \mathrm{a}$ & $2 \mathrm{a}$ & . & $1 \quad \mathbf{I V}$ \\
\hline $\mathrm{Th}$ & eur-as & Arenaria leptoclados & + & + & + & . . & . & .2 & $2 b$ & . & + & 12 & $2 \mathrm{~m}$. & . . & . + & . & . & + & . & + . & . . & . & . & 1 & . & . + & $+\quad+$ & ++ & . & . . & . III \\
\hline $\mathrm{H}$ & pont-med & Centaurea diffusa & ${ }^{\circ}$ & + & $\mathrm{r}$ & . + & + & . & . & + & . & 1 & $\mathrm{r}+$ & ++ & $+\quad$. & . & + & . & + & . . & . + & . & . & $\mathrm{r}$ & . & . . & . . & . . & . & . . & . II \\
\hline Th & eur-med & Trifolium campestre & . & . & . & . . & + & + & . & . & . & . & + . & . + &.+ & . & . & . & . & . . & . & . & . & . & + & . . & . 1 & $1+$ & 1 &. & . II \\
\hline $\mathrm{Th}$ & submed & Anthemis ruthenica & + & . & + & . + & $+\quad$. & . & $\mathrm{r}$ & + & + & + & . & . . & . . & $\mathrm{r}$ & . & + & . & . & . & . & . & . & . & . . & . & . & . & . . & . II \\
\hline Th & eur-as & Filago vulgaris & . & . & + & + . &. & . & . & . & . & . & $\mathrm{r}$. & . + & ++ & . & . & . & . & . + & + . & . & . & . & . & . . & . &. & + & . + & + II \\
\hline Th & subboreal & Vulpia myurus & . & . & . & . . & + & $\cdot 2$ & $2 \mathrm{a}$ & . & . & . & +1 & 1. & . . & + & . & . & . & . . & . . & . & . & . & + & . . & . & . . & . & 1 & . $\mathbf{I}$ \\
\hline $\mathrm{Th}$ & med-as & Trifolium scabrum & . & . & + & ++ & + & . & . & . & . & . & + . & . & . & . & . & . & . & . . & . + & . & . & . & . & . . & . & + . & . & .. & I \\
\hline Th & eur-med & Bombycilaena erecta & + & . & + & . . & $\cdot$ & . & $\mathrm{r}$ & . & + & . & . & . & . & . & . & . & . & + . & . & . & . & . & . & . . & . & . & . & . & I \\
\hline $\mathrm{Th}$ & eur-as & Arenaria serpyllifolia & $\cdot$ & . & . & . . &. & . & . & . & . & . & . & . & . & . & r. & . & $\theta^{\circ}$ & ${ }^{\circ}$ & . + & . & . & . & . & . . & . & . & . & . & I \\
\hline $\mathrm{Th}$ & boreal & Filago lutescens & . & . & . & . . & . & . & . & . & + & . & . . & . . & .. & . & . & . & . & . & $\cdot$ & . & . & . & . & . . & . & . & . & . & . $\mathbf{I}$ \\
\hline $\mathrm{Th}$ & submed & Scleranthus polycarpos & . & . & . & . 1 & 1. & . & . & . & . & . & . + & + . &. & . & . & . & + & . . & . & . & . & . & . & . . & . & . & . & . . & I \\
\hline Th & subboreal & Erodium cicutarium & . & . & . & . + & - & $\cdot 2$ & $2 b$ & . & . & + & . + & + . & . & . & . & . & . & + . & . & . & . & . & . & . . & . & . & . & . & I \\
\hline $\mathrm{Th}$ & submed & Psilurus incurvus & 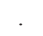 & . & . & . . & . & . & . & . & . & & + . & . &.+ & . & ${ }^{\circ}$ & . & . & . & . & . & $\cdot$ & . & . & . . & . & . & . & . . & . $\quad \mathbf{I}$ \\
\hline $\mathrm{H}$ & eur-med & Scleranthus perennis & $\cdot$ & . & . & . . & . & . & . & . & . & s. & . . & . . & . . & . & . & . & . & . & . & . & . & . & . & . . & . & . & . & . . & . \\
\hline $\mathrm{H}$ & eur-submed & Rumex acetosella & . & . & . & . . & . & . & . & . & . & . & .. & . . & .. & . & . & . & . & .. & . & . & . & . & . & . . & . . & $\cdot$ & . & $\cdot$. & $\cdot$ \\
\hline $\mathrm{H}$ & cosm; temp & Syntrichia ruralis & . & . & . & . & . & . & . & . & . & . & . . & . . & . & . & . & . & . & .. & . & . & . & . & . & . . & . & . & . & . . & . \\
\hline \multirow[t]{2}{*}{$\mathrm{Th}$} & submed & Silene subconica & . & . & . & . & . & . & . & . & . & . & . . & . & . & . & 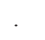 & . & . & . & . & . & . & . & . & . . & . & . & . & . & . \\
\hline & & Otl & & & & & & & & & & & & & & & & & & & & & & & & & & & & & \\
\hline $\mathrm{H}$ & $\operatorname{cosm}$ & Plantago lanceolata & + & . & + & ++ & - & + & $\mathrm{r}$ & 1 & 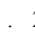 & $2 \mathrm{~b}$ & . . & . 1 & 1. & + & + & + & + & ++ & ++ & + & . & . & + & ++ & ++ & ++ & + & ++ & $+\mathbf{I V}$ \\
\hline $\mathrm{Th}$ & eur-as & Taeniatherum caput-medusae & $\cdot$ & $2 \mathrm{a}$ & . & $2 \mathrm{~b} 2 \mathrm{~m}$ & $\mathrm{n}$. & $2 \mathrm{a}$ & $\mathrm{r}$ & + & . & + & ++ & +1 & $12 b$ & + & + & . 2 & $2 \mathrm{a}$ & . 3 & $32 \mathrm{a}$ & a 1 & 5 & + & +2 & $2 \mathrm{~m} 2 \mathrm{~b}$ & $2 \mathrm{~b}$. & . $2 \mathrm{~m}$ & $1+2$ & $2 \mathrm{~m} 2 \mathrm{a}$ & a IV \\
\hline $\mathrm{H}$ & eur-sib & Cichorium intybus & + & . & $\mathrm{r}$ & + . & . & . & . & 1 & . & $\mathrm{r}$ & . + & ++ & + . & . & + & $\mathrm{r}$ & + & . + & + & . & + & $\mathrm{r}$ & . & . + & + . & $\mathrm{r}$ & . & . & + III \\
\hline $\mathrm{Th}$ & eur-as & Herniaria hirsuta & . & . & + & . + & - . & . & $\mathrm{r}$ & . & . & . & . . & . + & + . & . & . & . & + & + . & . & . & + & . & + & . + & + . & . & + & . & . II \\
\hline $\mathrm{H}$ & subboreal & Potentilla neglecta & + & + & + & . . & + & . & . & . & . & . & . . & .. &. & . & . & . & . & .. & . & . & + & . & . & . + & + . & $\cdot+$ & . & + & . II \\
\hline $\mathrm{Th}$ & eur-med & Medicago rigidula & . & . & . & $2 \mathrm{~b}$. & . & .2 & $2 b$ & . & $2 \mathrm{a}$ & +- & + . & . . & . 1 & . & . & . 2 & $2 \mathrm{a}$ & 1. & . & . & . & . & . & . . & . + & + . & 1 & . . & . II \\
\hline Th & eur-sib & Veronica arvensis & . & + & . & +1 & . & . & . & . & . & $1-$ & + . & . + & + . & . & . & . & . & + . & . & 1 & . & . & . & . . & . + & $+\quad+$ & + & . & . II \\
\hline $\mathrm{H}$ & submed & Dasypyrum villosum & . & + & . & . + & - & . & . & . & . & + & . & . & . & . & $\cdot 2$ & $2 \mathrm{a}$ & . & . + & + & . & . & + & 1 & ++ & + . & . & . & . & . II \\
\hline $\mathrm{H}$ & eur-as & Potentilla inclinata & . & . & . & . . & . & + & . & . & + & $\cdot$ & . . & . . & . & + & . & . & + &. & . & + & $\cdot$ & . & + & . + & + . & . & + & . & . II \\
\hline Th & eur-as & Aegilops triuncialis & . & . & . & . . & . & . & + & . & . & . & . 2 & $2 \mathrm{a}$. & . & 4 & . & 1 & . & .. & $\cdot+$ & . & + & . & 1 & + . & . & . & . & . . & . II \\
\hline Th & submed & Carthamus lanatus & 1 & . & . & $3 \mathrm{r}$ & . & + & + & 1 & . & . & . & . . & . $r$ & + & $\mathrm{r}$ & . & . & .. & . & . & . & . & . & . . & . & . & . & . . & . II \\
\hline $\mathrm{Th}$ & eur-med & Trifolium striatum & . & 1 & . & . & + & . & . & + & . & + & . + & + . & . $2 \mathrm{a}$ & . & . & + & . & . & . & . & + & . & . & . . & . & . $2 \mathrm{a}$ & . & . & . II \\
\hline $\mathrm{H}$ & eur-as & Dactylis glomerata & . & + & . & . . & . & $\mathrm{r}$ & . & . & . & . & . . & . & . & . & $\mathrm{r}$ & $\cdot$ & . & . + &.+ & $2 \mathrm{a}$ & . & + & + & . + & + . & . & $2 \mathrm{a}$ & 1 & . II \\
\hline $\mathrm{H}$ & $\operatorname{cosm}$ & Convolvulus arvensis & . & . & . & . . & . & . & + & $\mathrm{r}$ & . & . & . . & .. & .. & . & . & . & . & + . & $\cdot+$ & . & . & . & . & . + & + . & $\cdot+$ & + & + & . II \\
\hline $\mathrm{H}$ & eur-med & Lotus corniculatus & . & . & . & . . & . & + & . & + & . & . & . . & . . & . $\mathrm{r}$ & . & + & . & + & . . & . + & + & . & . & . & . + & + . & 1 & . & + & . II \\
\hline Th & med & Trifolium angustifolium & + & . & . & + & . & + & . & . & . & . & + . & . & $\cdot+$ & . & . & . & . & . & . & . & . & . & . & . + & + . & r & . & . . & . II \\
\hline Th & pont-as & Galium tenuissimum & . & . & . & + & . & . & . & . & . & . & + . & . & . & . & . & . & . & . & . 1 & . & . & . & . & + . & . & . & . & $+2 \mathrm{~m}$ & $\mathrm{~m} \mathbf{I}$ \\
\hline Th & eur-med & Cerastium pumilum & ${ }^{\circ}$ & . & . & . . & . & . & . & . & . & . & + . & . & . & . & . & 1 & . & + . & . & 1 & . & . & . & . . & . . & $\cdot$ & + & . & . $\mathbf{I}$ \\
\hline $\mathrm{Th}$ & submed & Nigella arvensis & . & + & . & . . & . & 1 & . & . & . & . & + . & . . & . & . & . & . & . & . . & . & . & . & + & . & . $\mathrm{r}$ & r. & . + & . & + & I \\
\hline Th & med & Trifolium retusum & . & . & . & . & . & . & . & . & . & . & + . & . . & . & . & . & . & . & .. & . & . & . & . & . & . . & . & . & . & . . & I \\
\hline $\mathrm{Th}$ & bal & Centaurea caliacrae & . & . & . & . & . & . & . & . & . & . & . & . & . & . & . & . & . & . & . & . & . & . & r & . . & . & . & . & . . & I \\
\hline $\mathrm{H}$ & eur-as & Astragalus hamosus & . & . & . & + . & . & . & . & . & . & . & . . & . & . & . & . & · & $\cdot$ & .. & . & . & . & . & . & . . & . & . & . & . & . $\mathbf{I}$ \\
\hline Th & boreal & Setaria viridis & $\cdot$ & . & . & . . & + & . & . & . & . & . & .. & . & . & . & . & . & . & . & . & . & . & . & . & . . & . & . & . & . . & I \\
\hline $\mathrm{H}$ & eur & Carduus acanthoides & . & . & . & . & . & . & . & . & . & . & + . & . & . & . & . & . & . & . & . & . & . & . & . & . . & . & . & . & $\mathrm{r}$. & . $\mathbf{I}$ \\
\hline $\mathrm{Th}$ & med & Trifolium setiferum & $\mathrm{r}$ & . & . & . & . & . & . & . & . & . & . & . & . & . & . & . & . & . & . & . & . & . & . & . . & . & . & . & . & . $\mathbf{I}$ \\
\hline $\mathrm{Th}$ & submed & Trifolium pallidum & . & . & . & . & 1 & . & . & . & . & . & . & . & . & . & . & . & . & . & . & . & . & . & . & . . & . & . & . & . & . $\quad \mathbf{I}$ \\
\hline $\mathrm{H}$ & eur-as & Ononis spinosa & . & . & . & . & . & 1 & . & . & . & . & . & . & . & . & . & . & . & . & . & . & . & . & . & . . & . & . & . & . $r$ & I \\
\hline $\mathrm{H}$ & eur-sib & Carex praecox & . & . & . & . & . & . & . & . & . & . & . & . & . & . & . & . & . & + . & . & . & . & . & . & . . & . & . & $2 \mathrm{~m}$ & . & I \\
\hline $\mathrm{H}$ & submed & Cynosurus echinatus & . & . & . & . & . & . & . & . & . & . & + . & . & . & . & . & . & . & . & . & + & . & . & . & . . & . & . & $\cdot 2$ & $2 \mathrm{~m}$. & . I \\
\hline $\mathrm{H}$ & pont-Cas & (S) Elymus hispidus & $\cdot$ & . & . & . & . & . & . & . & ${ }^{\circ}$ & & . & . & . & . & . & . & . & . & . & . & . & . & . & . & . & . $2 \mathrm{~m}$ & . & . & I \\
\hline Th & eur-as & Geranium rotundifolium & $\cdot$ & . & . & . & . & . & + & . & $\cdot$ & rat & . & . & . & . & . & . & . & . & . & . & · & . & . & . . & . & . & . & . & I \\
\hline $\mathrm{Th}$ & boreal & Bromus mollis & . & . & . & . & . & . & . & . & . & . & . & . & . & . & . & . & . & . & . & . & . & . & . & . + & + . & . & . & . & I \\
\hline $\mathrm{Th}$ & eur-med & Logfia arvensis & . & . & . & . & . & . & . & . & . & . & . & . + &.+ & . & . & . & . & .. & . & . & . & . & . & . . & . & . & . & . & I \\
\hline $\mathrm{Th}$ & boreal & Bromus tectorum & $\cdot$ & + & . & . & . & . & . & 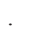 & . & . & . & . & . & . & . & . & . & . & . & . & . & . & . & . . & . & . & . & . . & I \\
\hline $\mathrm{Th}$ & submed & Alyssum strigosum & + & . & . & . & $\cdot$ & . & . & 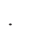 & ${ }^{\circ}$ & 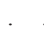 & . . & . & . & $\cdot$ & . & . & . & . & . & . & . & . & . & .. & . & . & . & . . & I \\
\hline Th & submed & Velezia rigida & . & . & . & . & . & . & . & . & . & + & + . & . + & + . & . & . & . & . & . & . & . & . & . & . & . . & . & . & . & . & I \\
\hline $\mathrm{Th}$ & $\operatorname{cosm}$ & (S) Anagallis arvensis & & $\cdot$ & $\cdot$ & . . & . & . & $\cdot$ & ${ }^{\circ}$ & . & & . . & . . & . . & $\cdot$ & . & . & $\cdot$ &. & . + & . & ${ }^{\circ}$ & . & & . & . + & + . & ${ }^{\circ}$ & . & I \\
\hline
\end{tabular}



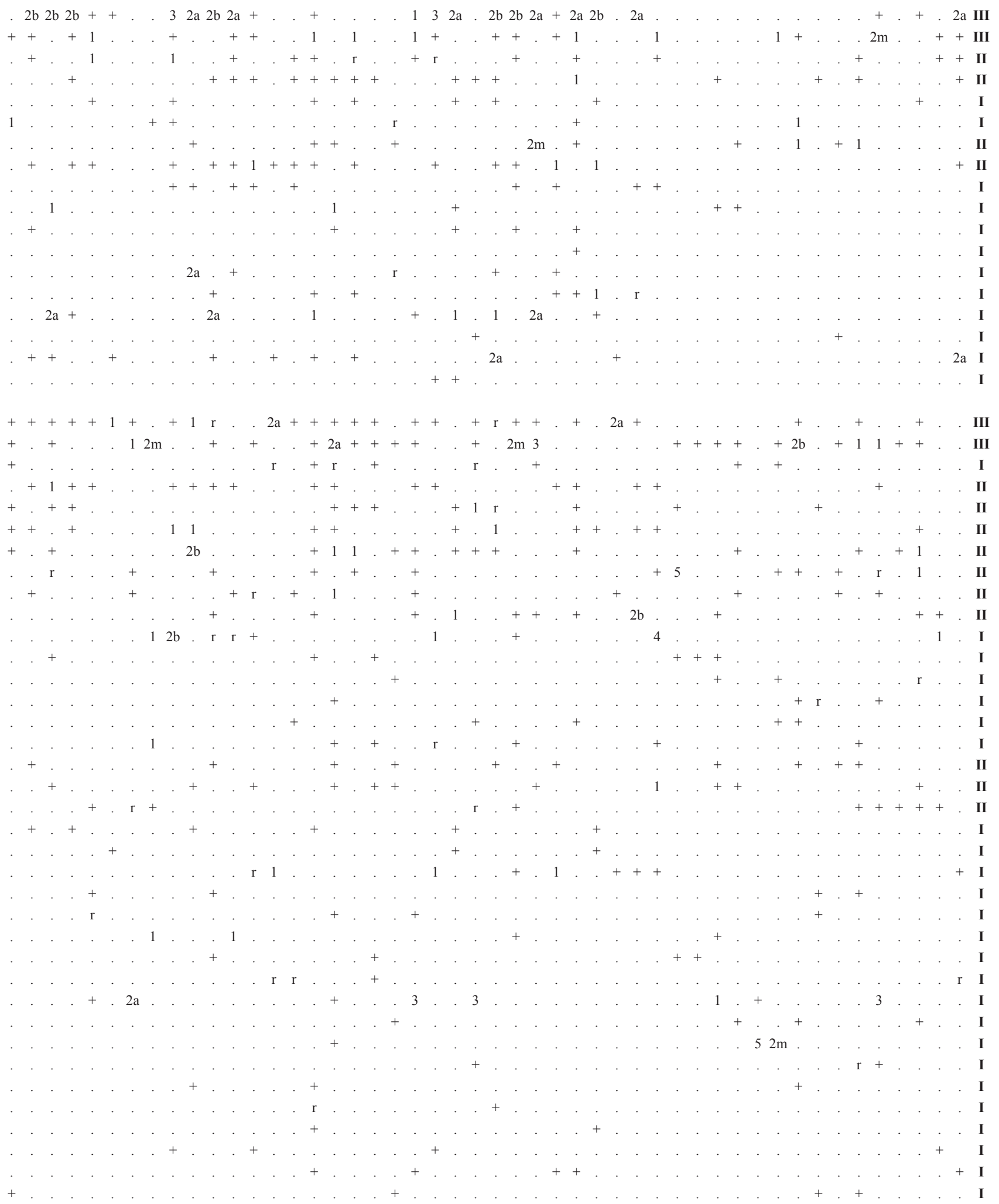
No. of relevé

$\begin{array}{lllllllllllllllllllllllllllllllll}1 & 2 & 3 & 4 & 5 & 6 & 7 & 8 & 9 & 10 & 11 & 12 & 13 & 14 & 15 & 16 & 17 & 18 & 19 & 20 & 21 & 22 & 23 & 24 & 25 & 26 & 27 & 28 & 29 & 30 & 31 & 32 & 33\end{array}$

\begin{tabular}{|c|c|c|c|c|c|c|c|c|c|c|c|c|c|c|c|c|c|c|c|c|c|c|c|c|c|c|c|c|c|c|c|c|c|c|c|c|}
\hline $\mathrm{H}$ & eur-submed & Achillea collina & & . & . & $\cdot$ & . & + & . & . & . & . & . & . & . & . & & . & & & & 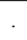 & 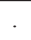 & & . & 1 & . & & . & - & ${ }^{\circ}$ & . & $\cdot$ & & 1 & I \\
\hline $\mathrm{H}$ & eur-as & Echium vulgare & . & . & $\mathrm{r}$ & . & + & . & . & + & . & . & . & . & . & . & . & . & . & $\cdot$ & . & . & $\mathrm{r}$ & $\cdot$ & + & . & . & ? & 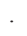 & . & . & . & $\cdot$ & & + & I \\
\hline $\mathrm{Th}$ & eur-as & Daucus carota & 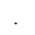 & . & . & . & . & . & . & . & + & . & . & . & . & . & 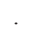 & . & 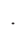 & & . & . & . & 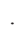 & . & . & . & . & . & . & . & . & ${ }^{\circ}$ & . & . & I \\
\hline $\mathrm{Th}$ & med & Trifolium echinatum & . & . & . & . & . & . & . & . & . & . & . & $\cdot$ & . & . & - & . & . & - & . & . & 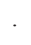 & . & . & . & 1 & . & . & . & . & . & . & . & . & I \\
\hline $\mathrm{H}$ & eur-sib & Anthemis tinctoria & . & . & . & . & . & . & . & . & . & . & . & . & . & . & . & . & . & . & . & . & . & + & . & . & . & . & . & . & . & . & . & . & . & I \\
\hline Th & eur-med & Vicia hirsuta & . & $\cdot$ & . & . & $\cdot$ & . & . & . & . & $\cdot$ & . & $\cdot$ & . & . & . & . & . & . & . & . & . & $\cdot$ & . & . & . & . & . & $\mathrm{r}$ & . & . & . & . & . & I \\
\hline $\mathrm{Th}$ & med-as & Trachynia distachya & . & . & . & . & . & . & 1 & . & . & . & . & . & . & . & . & . & . & . & 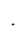 & 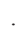 & 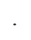 & $\cdot$ & 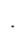 & 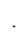 & . & . & 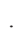 & 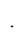 & . & 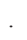 & . & . & . & I \\
\hline $\mathrm{Th}$ & $\operatorname{cosm}$ & Chenopodium album & $\cdot$ & $\cdot$ & $\cdot$ & $\cdot$ & . & . & . & . & . & $\cdot$ & $\mathrm{r}$ & $\cdot$ & $\cdot$ & $\cdot$ & $\cdot$ & . & . & 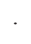 & . & t & - & . & . & 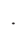 & . & 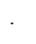 & . & . & . & 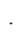 & . & . & . & I \\
\hline $\mathrm{Th}$ & med-Cas & Bromus japonicus & . & . & . & . & . & . & . & . & . & . & . & . & . & . & . & . & . & . & . & . & . & . & . & . & $2 \mathrm{~m}$ & $2 \mathrm{~m}$ & . & . & + & . & . & . & . & I \\
\hline Th & med & Sherardia arvensis & . & . & . & + & . & . & . & . & . & . & . & + & . & . & . & . & . & . & . & . & . & . & + & . & . & . & . & . & . & . & . & . & . & I \\
\hline Th & eur-as & Torilis arvensis & . & . & . & . & . & . & . & . & . & . & . & + & . & . & $\cdot$ & . & r & 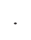 & . & . & . & . & + & . & + & . & . & . & . & . & . & . & . & I \\
\hline Th & med & Aegilops geniculata & . & . & . & 3 & . & . & . & . & . & . & . & $\cdot$ & . & + & $\cdot$ & . & . & + & + & + & . & . & $\cdot$ & . & . & . & ${ }^{\circ}$ & 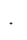 & . & ${ }^{\circ}$ & . & 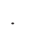 & . & I \\
\hline Th & $\operatorname{cosm}$ & Capsella bursa-pastoris & . & . & . & . & . & . & . & $\mathrm{r}$ & . & + & . & $\cdot$ & + & . & . & + & . & . & . & + & . & . & 1 & . & . & . & . & . & . & . & . & . & . & I \\
\hline $\mathrm{Th}$ & eur-as & Torilis nodosa & . & . & . & . & . & . & . & . & + & . & . & . & . & . & . & . & . & . & . & . & . & . & . & . & + & . & . & . & + & . & . & . & . & I \\
\hline $\mathrm{H}$ & & (S) Taraxacum sp. & . & $\cdot$ & . & . & $\cdot$ & . & . & . & . & $\cdot$ & + & $\cdot$ & . & . & . & . & . & . & 1 & . & . & + & . & $\cdot$ & . & . & . & . & . & . & . & . & . & I \\
\hline $\mathrm{H}$ & eur-submed & Phleum pratense & . & . & . & . & . & . & . & . & . & . & . & . & . & . & + & . & $\cdot$ & ${ }^{\circ}$ & . & 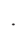 & . & + & ${ }^{\circ}$ & . & . & . & . & ${ }^{\circ}$ & $\cdot$ & ${ }^{\circ}$ & $2 \mathrm{~m}$ & 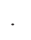 & ${ }^{\circ}$ & I \\
\hline $\mathrm{Th}$ & eur & Dianthus armeria & + & . & + & . & . & . & . & . & . & . & . & $\cdot$ & . & . & . & . & . & . & . & $\cdot$ & . & $\cdot$ & . & $\cdot$ & . & . & . & . & . & . & + & ${ }^{\circ}$ & . & I \\
\hline $\mathrm{H}$ & submed & Rorippa thracica & . & . & . & . & . & . & + & . & . & . & . & . & . & . & . & $2 \mathrm{~m}$ & . & . & . & . & . & . & . & . & . & . & . & . & . & . & . & . & . & I \\
\hline Th & eur-as & Medicago lupulina & . & . & . & . & $\cdot$ & . & . & . & . & $\cdot$ & . & + & . & . & . & . & . & 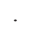 & ${ }^{\circ}$ & . & . & . & . & . & . & . & . & . & + & . & . & $\cdot$ & . & I \\
\hline Th & pont-med & (S) Bupleurum commutatum & . & + & . & . & . & . & . & . & . & $\cdot$ & . & $\cdot$ & . & . & $\cdot$ & . & . & 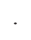 & . & . & $\cdot$ & + & . & $\cdot$ & . & . & . & $\cdot$ & $\cdot$ & . & . & . & . & I \\
\hline $\mathrm{Th}$ & submed & Trifolium incarnatum & $\cdot$ & $\cdot$ & + & . & . & . & . & . & . & + & . & $\cdot$ & $\cdot$ & . & $\cdot$ & . & . & $\cdot$ & 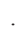 & 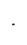 & $\cdot$ & $\cdot$ & 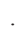 & $\cdot$ & . & . & $\cdot$ & $\cdot$ & $\cdot$ & . & . & ${ }^{\circ}$ & . & I \\
\hline Th & eur-med & Centaurea solstitialis & . & . & . & . & . & + & . & . & . & $\cdot$ & . & + & . & . & . & . & . & . & . & . & . & + & . & . & + & . & . & . & . & . & . & . & + & I \\
\hline $\mathrm{Th}$ & $\operatorname{cosm}$ & Polygonum aviculare & . & . & $\cdot$ & . & . & . & . & . & . & + & . & $\cdot$ & + & + & . & . & + & $\cdot$ & . & . & . & + & . & . & . & . & . & . & + & . & . & . & . & I \\
\hline $\mathrm{H}$ & $\operatorname{cosm}$ & Verbena officinalis & $\cdot$ & $\cdot$ & . & . & $\cdot$ & + & . & . & . & . & . & $\cdot$ & . & $\mathrm{r}$ & . & . & . & $\cdot$ & . & . & . & $\cdot$ & . & . & . & . & . & . & $\cdot$ & . & . & $\cdot$ & . & I \\
\hline $\mathrm{Th}$ & med & Bupleurum flavum & . & . & . & . & . & + & $2 \mathrm{a}$ & . & . & . & . & . & . & . & $\cdot$ & . & . & $\cdot$ & $\cdot$ & $\cdot$ & $\cdot$ & 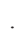 & $\cdot$ & . & . & . & . & $\cdot$ & $\cdot$ & . & . & $\cdot$ & . & I \\
\hline Th & pont-med & Cephalaria transsylvanica & . & . & . & . & . & + & $\mathrm{r}$ & . & . & . & . & $\cdot$ & . & . & 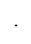 & . & . & . & 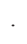 & . & 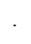 & 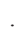 & $\cdot$ & . & . & . & . & . & . & . & . & $\cdot$ & . & I \\
\hline Th & eur-as & Phleum subulatum & . & . & . & + & . & . & . & . & . & . & . & $\mathrm{r}$ & . & . & . & . & . & . & . & . & + & . & . & . & $2 \mathrm{~m}$ & 1 & . & . & . & . & . & $2 \mathrm{a}$ & . & I \\
\hline $\mathrm{H}$ & pont & Potentilla argentea & $\cdot$ & . & . & + & . & . & . & . & . & $\cdot$ & . & $\cdot$ & $\cdot$ & . & . & . & . & $\cdot$ & $\cdot$ & $\cdot$ & $\cdot$ & $\cdot$ & $\cdot$ & . & . & . & . & . & . & . & $2 \mathrm{a}$ & . & . & I \\
\hline $\mathrm{H}$ & submed & Marrubium peregrinum & . & . & . & . & . & . & . & . & . & . & . & + & . & . & . & . & $\cdot$ & 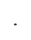 & 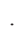 & $\cdot$ & 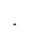 & $\cdot$ & $\cdot$ & $\cdot$ & . & . & $\cdot$ & . & + & . & . & . & $\cdot$ & I \\
\hline $\mathrm{Th}$ & subboreal & Apera spica-venti & . & . & $\cdot$ & . & . & . & . & . & . & . & . & . & . & $\cdot$ & $\cdot$ & . & . & $\cdot$ & 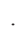 & $\cdot$ & $\cdot$ & 1 & 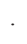 & $\cdot$ & . & + & $\mathrm{r}$ & $\cdot$ & $\cdot$ & · & . & · & $\cdot$ & I \\
\hline $\mathrm{H}$ & boreal & Hordeum murinum & . & . & . & + & . & . & . & + & . & . & . & $\cdot$ & . & . & . & . & . & . & . & . & . & $\cdot$ & . & . & . & . & . & . & . & . & . & . & . & I \\
\hline $\mathrm{H}$ & pont-med & Ajuga chamaepytis & $\cdot$ & $\cdot$ & $\cdot$ & . & $\cdot$ & . & . & . & . & $\cdot$ & . & $\cdot$ & $\cdot$ & $\cdot$ & . & . & . & . & . & . & $\cdot$ & $\cdot$ & . & . & . & . & . & . & + & . & . & . & . & I \\
\hline $\mathrm{H}$ & eur-med & Agrimonia eupatoria & . & . & . & . & . & + & . & . & . & . & . & . & . & . & $\cdot$ & . & . & $\cdot$ & $\cdot$ & . & $\mathrm{r}$ & . & . & . & . & . & . & . & . & . & . & $\cdot$ & . & $\mathbf{I}$ \\
\hline $\mathrm{H}$ & eur-sib & Inula hirta & . & . & . & . & . & . & . & . & $\cdot$ & $\cdot$ & . & . & . & · & $\cdot$ & . & + & $\cdot$ & 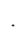 & $\cdot$ & 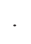 & . & $\cdot$ & $\cdot$ & · & . & $\cdot$ & $\cdot$ & $\cdot$ & + & . & $\cdot$ & $\cdot$ & I \\
\hline $\mathrm{H}$ & med & Scorzonera laciniata & . & . & . & . & . & . & . & . & + & . & . & $\cdot$ & . & . & . & . & + & + & . & . & . & $\cdot$ & . & . & . & . & + & . & . & . & . & . & . & I \\
\hline $\mathrm{H}$ & eur-med & Hypochaeris radicata & . & . & . & . & . & . & . & . & . & $\cdot$ & . & $\cdot$ & $\cdot$ & . & . & . & . & . & . & . & $\cdot$ & $\cdot$ & . & . & . & . & . & . & . & . & . & $\cdot$ & . & $\cdot$ \\
\hline $\mathrm{H}$ & eur-med & Sedum acre & . & . & $\cdot$ & . & . & . & . & . & . & $\cdot$ & . & $\cdot$ & . & . & · & . & . & $\cdot$ & $\cdot$ & $\cdot$ & $\cdot$ & $\cdot$ & $\cdot$ & . & . & . & . & . & $\cdot$ & . & . & . & . & . \\
\hline $\mathrm{H}$ & med & Euphorbia niciciana & . & . & . & . & . & . & . & . & . & . & · & . & . & . & $\cdot$ & . & $\cdot$ & $\cdot$ & 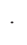 & 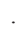 & . & . & $\cdot$ & . & . & . & . & . & . & . & . & . & . & $\cdot$ \\
\hline $\mathrm{Ch}$ & alp-med & Helianthemum nummularium & . & . & . & . & . & . & . & . & . & . & . & . & . & . & · & . & $\cdot$ & $\cdot$ & $\cdot$ & $\cdot$ & 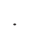 & $\cdot$ & $\cdot$ & $\cdot$ & . & . & $\cdot$ & $\cdot$ & $\cdot$ & $\cdot$ & . & $\cdot$ & . & . \\
\hline Th & subboreal & Tragus racemosus & . & . & . & . & . & . & . & . & . & $\cdot$ & . & $\cdot$ & . & . & . & . & . & . & . & . & . & . & . & . & . & . & . & . & . & . & . & . & . & . \\
\hline $\mathrm{Th}$ & med-Cas & Cruciata pedemontana & . & . & . & . & . & . & . & . & . & $\cdot$ & . & $\cdot$ & $\cdot$ & . & . & . & . & $\cdot$ & . & . & $\cdot$ & $\cdot$ & . & . & . & . & . & . & . & . & . & . & . & - \\
\hline $\mathrm{H}$ & bal & Hypericum rumeliacum & . & . & . & . & . & . & . & . & . & . & . & . & . & . & . & . & . & . & $\cdot$ & . & $\cdot$ & $\cdot$ & $\cdot$ & . & . & . & . & . & . & . & . & . & . & $\cdot$ \\
\hline $\mathrm{Th}$ & submed & Sideritis montana & . & . & . & . & . & . & . & . & . & $\cdot$ & . & . & . & . & . & . & $\cdot$ & $\cdot$ & $\cdot$ & $\cdot$ & . & $\cdot$ & $\cdot$ & $\cdot$ & . & . & $\cdot$ & $\cdot$ & $\cdot$ & $\cdot$ & . & $\cdot$ & . & - \\
\hline $\mathrm{Th}$ & med & Scolymus hispanicus & . & . & . & . & . & . & . & . & . & $\cdot$ & . & . & . & . & . & . & . & . & $\cdot$ & $\cdot$ & $\cdot$ & . & $\cdot$ & . & . & . & . & . & . & . & . & . & . & . \\
\hline $\mathrm{H}$ & boreal & Rumex crispus & . & . & . & . & . & . & . & . & . & $\cdot$ & . & . & . & . & 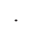 & . & . & 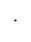 & . & . & . & . & . & . & . & . & . & . & . & . & . & . & . & $\cdot$ \\
\hline $\mathrm{H}$ & bal & Peucedanum vitijugum & . & . & . & . & . & . & . & . & . & . & . & . & . & . & . & . & . & . & 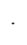 & $\cdot$ & . & 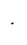 & $\cdot$ & . & . & . & . & . & . & . & . & . & . & $\cdot$ \\
\hline $\mathrm{H}$ & pont-med & Achillea coarctata & . & . & . & . & . & . & . & . & . & . & . & . & . & $\cdot$ & . & . & . & . & . & . & . & . & . & . & . & . & . & . & . & . & . & . & . & . \\
\hline Th & med & Linum bienne & $\cdot$ & . & . & . & $\cdot$ & . & . & . & . & . & $\cdot$ & $\cdot$ & . & . & $\cdot$ & . & . & - & 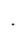 & . & $\cdot$ & 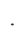 & . & . & . & . & $\cdot$ & $\cdot$ & $\cdot$ & . & . & . & . & . \\
\hline Th & eur-med & Bilderdykia dumetorum & . & . & . & . & . & . & . & . & . & . & . & . & . & . & . & . & . & . & $\cdot$ & $\cdot$ & . & . & $\cdot$ & . & . & . & . & . & . & . & . & . & . & 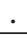 \\
\hline
\end{tabular}




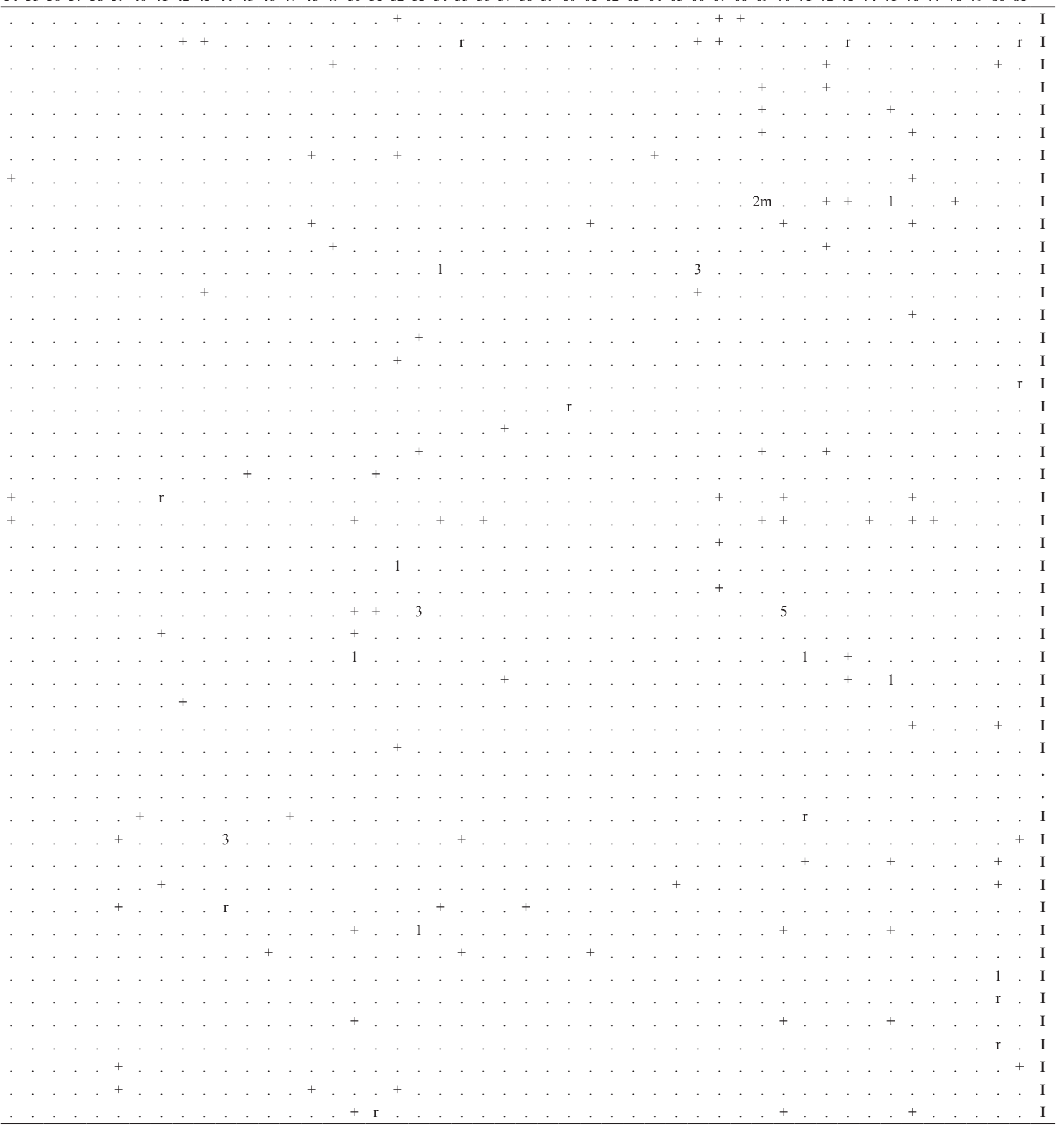


Table 3: Relevés of the association Festuco valesiacae-Stipetum capillatae Sillinger 1930.

Tabela 3: Popisi asociacije Festuco valesiacae-Stipetum capillatae Sillinger 1930.

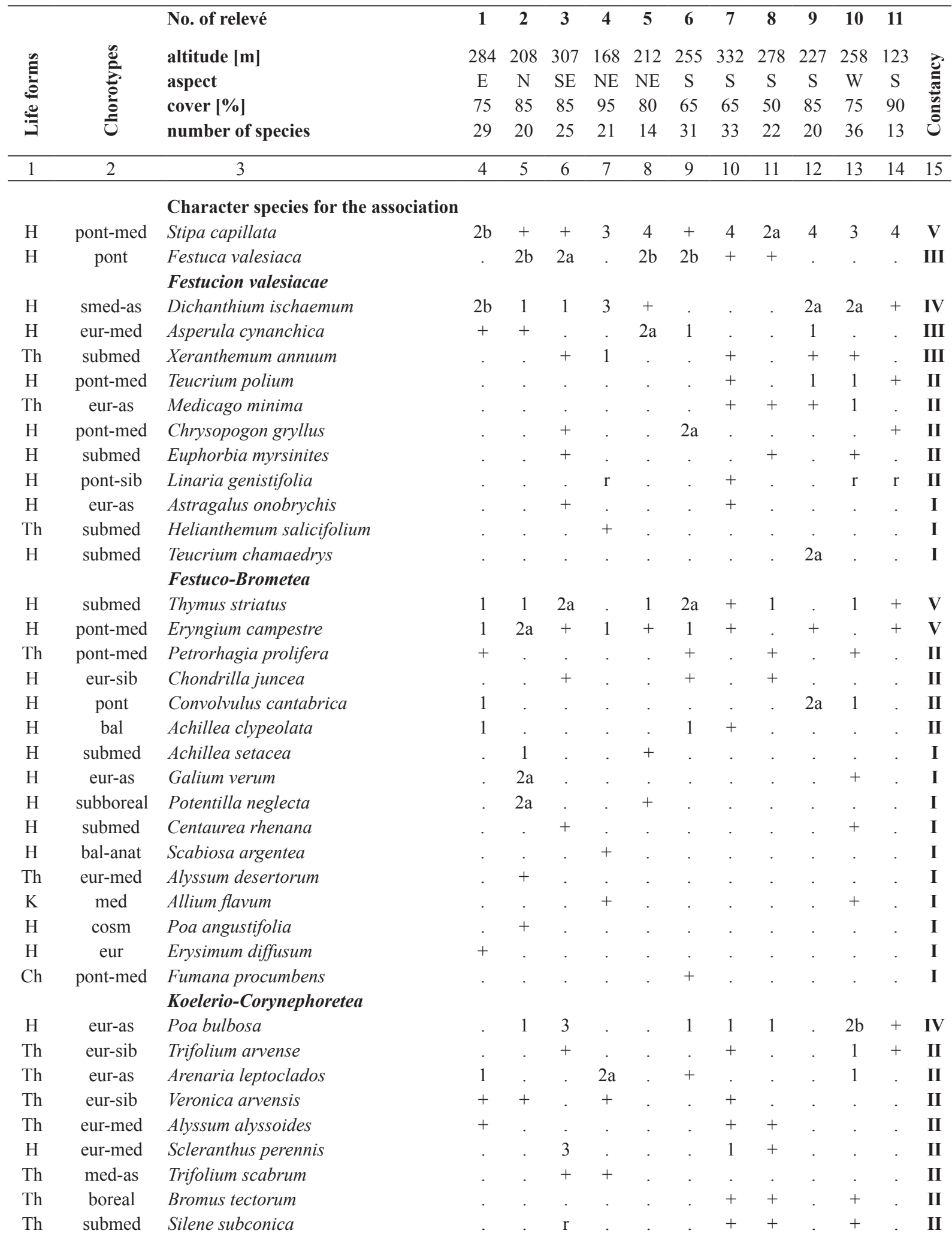




\begin{tabular}{|c|c|c|c|c|c|c|c|c|c|c|c|c|c|c|}
\hline & & No. of relevé & 1 & 2 & 3 & 4 & 5 & 6 & 7 & 8 & 9 & 10 & 11 & \\
\hline $\mathrm{H}$ & cosm;temp & Ceratodon purpureus & . & . & $2 \mathrm{a}$ & . & . & + & . & . & . & . & 1 & II \\
\hline Th & pont-med & Centaurea diffusa & . & . & . & . & . & $\mathrm{r}$ & + & . & $\mathrm{r}$ & . & . & II \\
\hline $\mathrm{H}$ & eur-med & Sedum acre & . & . & + & . & . & . & . & + & . & + & . & II \\
\hline $\mathrm{H}$ & cosm;temp & Syntrichia ruralis & . & . & + & + & . & . & . & . & . & + & . & II \\
\hline Th & eur-med & Trifolium campestre & + & . & . & . & . & 1 & . & . & . & . & . & I \\
\hline $\mathrm{Th}$ & subboreal & Vulpia myurus & + & + & . & . & . & . & . & . & . & . & . & I \\
\hline Th & boreal & Filago lutescens & + & . & . & . & . & . & . & + & . & . & . & I \\
\hline Th & submed & Psilurus incurvus & . & + & . & . & . & . & + & . & . & . & . & I \\
\hline Th & submed & Anthemis ruthenica & . & . & . & . & . & . & + & + & . & . & . & I \\
\hline Th & subboreal & Apera spica-venti & . & . & . & + & . & . & . & . & . & . & . & I \\
\hline Th & subboreal & Erodium cicutarium & . & . & . & . & . & . & + & . & . & . & . & I \\
\hline Th & eur-as & Filago vulgaris & + & . & . & . & . & . & . & . & . & . & . & I \\
\hline Th & eur-as & Herniaria glabra & . & . & . & . & . & . & + & . & . & . & . & I \\
\hline $\mathrm{H}$ & eur-as & Phleum phleoides & . & . & . & . & + & . & . & . & . & . & . & I \\
\hline Th & eur-med & $\begin{array}{l}\text { Bombycilaena erecta } \\
\text { Other species }\end{array}$ & . & . & . & . & . & . & . & . & . & + & . & I \\
\hline Th & eur-as & Herniaria hirsuta & . & + & . & + & + & + & + & . & . & . & + & III \\
\hline Th & eur-as & Taeniatherum caput-medusae & 1 & . & $\mathrm{r}$ & . & . & . & + & . & . & . & . & II \\
\hline $\mathrm{H}$ & pont-Cas & (S) Elymus hispidus & . & + & . & + & $2 \mathrm{a}$ & . & . & . & . & . & . & II \\
\hline Th & submed & Bromus squarrosus & . & . & $\mathrm{r}$ & . & . & . & + & + & . & + & . & II \\
\hline Th & eur-as & Crepis setosa & + & . & + & . & . & . & . & . & + & + & . & II \\
\hline $\mathrm{H}$ & $\operatorname{cosm}$ & Convolvulus arvensis & + & + & . & . & + & + & . & . & . & . & . & II \\
\hline $\mathrm{H}$ & submed & Marrubium peregrinum & + & $2 \mathrm{a}$ & . & . & + & . & . & . & . & . & . & II \\
\hline $\mathrm{H}$ & pont & Koeleria nitidula & . & . & . & . & . & 1 & 1 & $2 \mathrm{a}$ & . & + & . & II \\
\hline Th & eur-med & Medicago rigidula & . & . & + & . & . & + & . & + & . & . & . & II \\
\hline Th & boreal & Setaria viridis & + & . & . & . & . & + & + & . & . & . & . & II \\
\hline $\mathrm{H}$ & bal-dac & Melica transsilvanica & . & $\mathrm{r}$ & . & . & $\mathrm{r}$ & . & . & . & . & + & . & I \\
\hline
\end{tabular}


Table 4: Relevés of the association Medicagini-Festucetum valesiacae Wagner 1941.

Tabela 4: Popisi asociacije Medicagini-Festucetum valesiacae Wagner 1941.

\begin{tabular}{|c|c|c|c|c|c|c|c|c|c|c|c|c|c|c|c|}
\hline \multirow{5}{*}{ 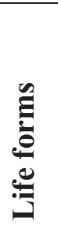 } & \multirow{5}{*}{$\frac{d}{\stackrel{0}{0}}$} & No. of relevé & \multirow{2}{*}{$\begin{array}{c}1 \\
194\end{array}$} & \multirow{2}{*}{$\begin{array}{c}\mathbf{2} \\
200\end{array}$} & \multirow{2}{*}{$\begin{array}{c}3 \\
199\end{array}$} & \multirow{2}{*}{$\begin{array}{c}4 \\
207\end{array}$} & 5 & 6 & 7 & 8 & 9 & 10 & 11 & 12 & \multirow{5}{*}{ 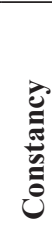 } \\
\hline & & altitude [m] & & & & & 115 & 269 & 225 & 228 & 329 & 273 & 253 & 165 & \\
\hline & & aspect & $\mathrm{W}$ & $\mathrm{N}$ & W & $\mathrm{N}$ & NW & SE & $\mathrm{N}$ & $\mathrm{N}$ & $\mathrm{W}$ & $\mathrm{W}$ & $\mathrm{N}$ & W & \\
\hline & & cover $[\%]$ & 95 & 85 & 90 & 85 & 95 & 75 & 85 & 95 & 75 & 85 & 95 & 90 & \\
\hline & & number of species & 21 & 31 & 21 & 25 & 22 & 23 & 23 & 25 & 30 & 24 & 23 & 29 & \\
\hline \multirow[t]{2}{*}{1} & 2 & 3 & 4 & 5 & 6 & 7 & 8 & 9 & 10 & 11 & 12 & 13 & 14 & 15 & 16 \\
\hline & & Character species for the ass & & & & & & & & & & & & & \\
\hline $\mathrm{Th}$ & eur-as & Medicago minima & $2 b$ & 1 & . & + & $2 \mathrm{a}$ & 1 & . & + & + & + & + & + & $\mathbf{V}$ \\
\hline $\mathrm{H}$ & eur-as & Poa bulbosa & 1 & 1 & . & . & + & $2 \mathrm{~m}$ & $2 \mathrm{a}$ & . & $2 \mathrm{a}$ & . & $2 \mathrm{a}$ & 3 & IV \\
\hline $\mathrm{H}$ & eur-as & Medicago falcata & + & + & + & + & + & + & . & + & . & . & . & . & III \\
\hline $\mathrm{H}$ & eur-as & Astragalus onobrychis & . & . & + & . & + & + & . & + & + & + & $2 \mathrm{a}$ & 1 & III \\
\hline & & Festucion valesiacae & & & & & & & & & & & & & \\
\hline $\mathrm{H}$ & pont & Festuca valesiaca & $2 b$ & $2 \mathrm{a}$ & 3 & $2 b$ & 3 & $2 b$ & 3 & 5 & $2 b$ & 4 & 4 & 3 & $\mathbf{V}$ \\
\hline $\mathrm{H}$ & eur-med & Asperula cynanchica & + & + & + & . & + & + & . & . & + & + & . & . & III \\
\hline $\mathrm{H}$ & Smed-as & Dichanthium ischaemum & $2 \mathrm{~b}$ & $2 \mathrm{a}$ & . & $2 b$ & $2 b$ & 1 & . & . & . & $2 \mathrm{a}$ & . & $\mathrm{r}$ & III \\
\hline $\mathrm{H}$ & pont-med & Teucrium polium & + & . & . & $2 \mathrm{a}$ & . & 1 & . & + & . & + & + & . & III \\
\hline $\mathrm{H}$ & submed & Teucrium chamaedrys & . & . & . & + & . & + & . & + & . & + & . & . & II \\
\hline $\mathrm{H}$ & submed & Euphorbia myrsinites & . & . & . & . & . & . & . & $\mathrm{r}$ & + & + & + & . & II \\
\hline Th & submed & Helianthemum salicifolium & . & . & . & . & . & . & . & . & + & . & 1 & . & $\mathbf{I}$ \\
\hline $\mathrm{H}$ & pont-med & Stipa capillata & . & . & . & . & . & . & . & . & . & + & + & . & $\mathbf{I}$ \\
\hline Th & submed & Xerantheтит aпnиит & . & + & . & . & . & . & . & . & . & . & . & . & $\mathbf{I}$ \\
\hline $\mathrm{H}$ & eur & Euphorbia cyparisias & . & . & . & . & . & . & 1 & . & . & . & . & . & I \\
\hline & & Festuco-Brometea & & & & & & & & & & & & & \\
\hline $\mathrm{H}$ & pont-med & Eryngium campestre & 1 & 1 & + & + & + & + & 1 & $\mathrm{r}$ & + & + & + & + & $\mathbf{V}$ \\
\hline $\mathrm{H}$ & submed & Thymus striatus & 1 & + & 1 & $2 \mathrm{a}$ & $2 b$ & + & + & 1 & $2 b$ & 1 & + & $2 \mathrm{a}$ & $\mathbf{V}$ \\
\hline Th & pont-med & Petrorhagia prolifera & + & + & + & . & . & . & + & . & + & . & + & + & III \\
\hline $\mathrm{H}$ & submed & Achillea setacea & . & 1 & . & . & + & . & + & + & . & . & + & . & III \\
\hline $\mathrm{H}$ & eur-as & Galium verum & . & . & + & . & 1 & . & . & 1 & . & 1 & + & + & III \\
\hline $\mathrm{H}$ & pont-med & Chrysopogon gryllus & . & . & $2 \mathrm{~b}$ & 1 & . & . & . & + & . & . & . & . & II \\
\hline $\mathrm{H}$ & eur-sib & Chondrilla juncea & . & . & . & . & . & . & $\mathrm{r}$ & . & . & $\mathrm{r}$ & + & $\mathrm{r}$ & II \\
\hline $\mathrm{H}$ & subboreal & Sanguisorba minor & . & $\mathrm{r}$ & . & + & . & . & . & + & . & . & . & . & II \\
\hline $\mathrm{Th}$ & eur-med & Alyssum desertorum & . & + & . & . & . & . & + & . & + & . & . & . & II \\
\hline $\mathrm{H}$ & subboreal & Potentilla neglecta & . & . & + & . & . & . & + & . & . & . & . & + & II \\
\hline $\mathrm{H}$ & bal & Achillea clypeolata & + & . & . & . & . & . & . & . & . & . & . & . & I \\
\hline $\mathrm{H}$ & bal-anat & Scabiosa argentea & . & . & . & + & . & . & . & . & . & . & . & . & $\mathbf{I}$ \\
\hline $\mathrm{H}$ & & (S) Hieracium praealtum & . & . & . & + & . & . & . & . & . & . & . & . & I \\
\hline Th & eur-med & Trifolium striatum & . & + & . & . & . & . & . & . & . & . & . & . & $\mathbf{I}$ \\
\hline $\mathrm{Ch}$ & alp-med & Helianthemum nummularium & . & . & . & . & . & . & $2 \mathrm{a}$ & . & . & . & . & . & I \\
\hline $\mathrm{H}$ & eur & Erysimum diffusum & . & . & . & . & . & . & . & . & + & . & . & . & $\mathbf{I}$ \\
\hline & & Koelerio-Corynephoretea & & & & & & & & & & & & & \\
\hline $\mathrm{H}$ & pont-med & Centaurea diffusa & $\mathrm{r}$ & + & . & + & + & + & . & . & + & . & . & . & III \\
\hline $\mathrm{Th}$ & med-as & Trifolium scabrum & . & . & . & . & + & . & 1 & + & + & 1 & + & . & III \\
\hline $\mathrm{Th}$ & eur-med & Bombycilaena erecta & + & . & . & . & . & + & + & + & . & . & . & . & II \\
\hline Th & eur-med & Trifolium campestre & . & + & . & + & . & . & . & + & . & + & . & . & II \\
\hline Th & subboreal & Erodium cicutarium & . & + & . & . & . & . & . & . & + & . & . & + & II \\
\hline $\mathrm{H}$ & cosm; temp & Syntrichia ruralis & . & . & . & . & . & + & . & + & . & . & . & 1 & II \\
\hline Th & submed & Psilurus incurvus & . & . & . & . & . & . & $2 \mathrm{~m}$ & . & + & . & . & . & I \\
\hline $\mathrm{Th}$ & eur-med & Alyssum alyssoides & + & . & . & . & . & . & . & . & . & . & . & . & I \\
\hline
\end{tabular}




\begin{tabular}{|c|c|c|c|c|c|c|c|c|c|c|c|c|c|c|c|}
\hline & & No. of relevé & 1 & 2 & 3 & 4 & 5 & 6 & 7 & 8 & 9 & 10 & 11 & 12 & \\
\hline $\mathrm{Th}$ & eur-sib & Trifolium arvense & . & . & + & . & . & . & . & . & . & . & . & . & $\mathbf{I}$ \\
\hline $\mathrm{H}$ & eur-med & Sedum acre & . & . & . & . & . & + & . & . & . & . & . & . & I \\
\hline $\mathrm{Th}$ & submed & Anthemis ruthenica & . & . & . & . & . & . & 1 & . & . & . & . & . & I \\
\hline $\mathrm{Th}$ & subboreal & Vulpia myurus & . & . & . & . & . & . & $2 \mathrm{~m}$ & . & . & . & . & . & I \\
\hline $\mathrm{Th}$ & boreal & Bromus tectorum & . & . & . & . & . & . & . & . & 1 & . & . & . & I \\
\hline $\mathrm{Th}$ & eur-sib & Veronica arvensis & . & . & . & . & . & . & . & . & + & . & . & + & $\mathbf{I}$ \\
\hline Th & submed & Silene subconica & . & . & . & . & . & $\cdot$ & . & . & + & . & . & . & I \\
\hline Th & eur-as & Arenaria leptoclados & . & . & . & . & . & . & . & . & + & . & . & + & I \\
\hline $\mathrm{Th}$ & eur-sib & Scleranthus annuus & . & . & . & . & . & . & . & . & . & + & . & . & I \\
\hline $\mathrm{H}$ & eur-med & Scleranthus perennis & . & . & . & . & . & . & . & . & . & . & + & . & I \\
\hline $\mathrm{H}$ & cosm; temp & $\begin{array}{l}\text { Ceratodon purpureus } \\
\text { Other species }\end{array}$ & . & . & . & . & . & . & . & . & . & . & . & 1 & I \\
\hline $\mathrm{H}$ & $\operatorname{cosm}$ & Plantago lanceolata & . & + & . & + & 1 & . & + & + & . & + & . & + & III \\
\hline $\mathrm{Th}$ & eur-med & Crepis setosa & + & + & . & . & . & . & + & + & . & . & + & + & III \\
\hline $\mathrm{H}$ & eur-as & Potentilla inclinata & + & . & . & . & + & . & . & + & + & . & + & . & III \\
\hline Th & eur-as & Herniaria hirsuta & . & + & . & . & + & + & . & . & + & . & + & + & III \\
\hline $\mathrm{Th}$ & submed & Bromus squarrosus & . & + & . & . & + & . & . & . & $2 \mathrm{a}$ & + & . & + & III \\
\hline Th & eur-med & Medicago rigidula & 1 & 1 & . & . & + & $\cdot$ & . & . & . & . & . & 1 & II \\
\hline Th & eur-as & Taeniatherum caput-medusae & . & 1 & . & . & + & . & + & . & . & . & . & . & II \\
\hline $\mathrm{H}$ & submed & Dasypyrum villosum & . & $\mathrm{r}$ & . & . & . & . & . & . & + & . & + & . & II \\
\hline $\mathrm{H}$ & eur-med & Carduus nutans & $\cdot$ & + & $\cdot$ & . & $\cdot$ & $\cdot$ & . & $\cdot$ & + & . & + & · & II \\
\hline $\mathrm{H}$ & eur-sib & Cichorium inthybus & . & . & . & . & . & . & + & . & . & $\mathrm{r}$ & . & $\mathrm{r}$ & II \\
\hline Th & eur-as & Aegilops triuncialis & . & + & . & . & . & 1 & . & . & + & . & . & . & II \\
\hline $\mathrm{Th}$ & bal & Centaurea caliacrae & . & . & + & . & . & . & . & . & + & + & . & 1 & II \\
\hline
\end{tabular}


Table 5: Relevés of the association Trifolio arvensis-Festucetum valesiacae Sopotlieva \& Apostolova 2013.

Tabela 5: Popisi asociacije Trifolio arvensis-Festucetum valesiacae Sopotlieva \& Apostolova 2013.

\begin{tabular}{|c|c|c|c|c|c|c|c|c|c|c|c|c|c|c|}
\hline \multirow{5}{*}{ 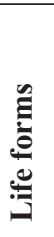 } & \multirow{5}{*}{ 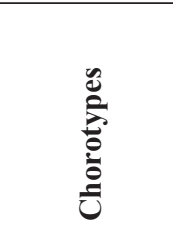 } & \multirow{5}{*}{$\begin{array}{l}\text { No. of relevé } \\
\text { altitude }[\mathrm{m}] \\
\text { aspect } \\
\text { cover }[\%] \\
\text { number of species }\end{array}$} & \multirow{2}{*}{$\begin{array}{c}1 \\
168\end{array}$} & \multirow{2}{*}{$\begin{array}{c}\mathbf{2} \\
259\end{array}$} & \multirow{2}{*}{$\begin{array}{c}3 \\
337\end{array}$} & \multirow{2}{*}{$\begin{array}{c}4 \\
245\end{array}$} & \multirow{2}{*}{$\begin{array}{c}5 \\
292\end{array}$} & \multirow{2}{*}{$\begin{array}{c}6 \\
333\end{array}$} & \multirow{2}{*}{$\begin{array}{c}7 \\
268\end{array}$} & \multirow{2}{*}{$\begin{array}{c}8 \\
199\end{array}$} & \multirow{2}{*}{$\begin{array}{c}9 \\
150\end{array}$} & \multirow{2}{*}{$\begin{array}{c}10 \\
324\end{array}$} & \multicolumn{2}{|l|}{11} \\
\hline & & & & & & & & & & & & & 284 & 3 \\
\hline & & & $\mathrm{SE}$ & $\mathrm{N}$ & $\mathrm{NE}$ & $\mathrm{N}$ & $\mathrm{NE}$ & S & $\mathrm{N}$ & $\mathrm{W}$ & NW & SW & W & Е \\
\hline & & & 95 & 95 & 95 & 85 & 85 & 90 & 95 & 90 & 85 & 85 & 90 & $\ddot{气}$ \\
\hline & & & 23 & 27 & 25 & 35 & 42 & 28 & 31 & 22 & 33 & 26 & 26 & e \\
\hline 1 & 2 & 3 & 4 & 5 & 6 & 7 & 8 & 9 & 10 & 11 & 12 & 13 & 14 & 15 \\
\hline & & Diagnostic species for the as & & & & & & & & & & & & \\
\hline $\mathrm{H}$ & subboreal & Potentilla neglecta & . & + & + & + & + & . & + & + & . & + & + & IV \\
\hline Th & eur-as & Herniaria hirsuta & . & . & + & + & + & + & + & + & + & + & . & IV \\
\hline $\mathrm{H}$ & eur-sib & Chondrilla juncea & . & + & + & $\mathrm{r}$ & + & + & + & . & . & + & + & IV \\
\hline $\mathrm{K}$ & pont-submed & Ornithogalum umbellatum & . & + & $\mathrm{r}$ & . & . & + & . & + & 1 & . & . & III \\
\hline $\mathrm{Th}$ & eur & Odontites serotina & . & + & . & + & + & . & . & & . & . & . & II \\
\hline & & Festucion valesiasacae & & & & & & & & & & & & \\
\hline $\mathrm{H}$ & pont & Festuca valesiaca & 3 & 5 & 4 & 3 & 3 & 4 & 4 & 4 & $2 b$ & 3 & 4 & $\mathbf{V}$ \\
\hline $\mathrm{H}$ & eur-med & Asperula cynanchica & . & . & . & 1 & + & . & + & + & . & . & + & III \\
\hline $\mathrm{H}$ & pont-med & Chrysopogon gryllus & 1 & . & . & . & . & . & . & + & $\mathrm{r}$ & $2 \mathrm{a}$ & + & III \\
\hline $\mathrm{H}$ & pont-med & Teucrium polium & + & . & . & . & $2 \mathrm{a}$ & + & . & . & . & + & . & II \\
\hline $\mathrm{H}$ & eur-as & Astragalus onobrychis & . & . & . & . & 1 & $2 b$ & . & $2 \mathrm{a}$ & . & . & . & II \\
\hline $\mathrm{H}$ & smed-as & Dichanthium ischaemum & + & . & . & . & . & . & . & . & . & . & + & $\mathbf{I}$ \\
\hline Th & eur-as & Medicago minima & $2 \mathrm{a}$ & . & + & . & . & . & . & . & . & . & . & I \\
\hline Th & submed & Helianthemum salicifolium & . & . & . & . & . & . & . & . & 1 & 1 & . & I \\
\hline $\mathrm{H}$ & eur & Euphorbia cyparissias & $\mathrm{r}$ & . & 1 & . & . & . & . & . & . & . & . & $\mathbf{I}$ \\
\hline $\mathrm{H}$ & submed & Teucrium chamaedrys & . & + & . & . & . & . & . & . & . & + & . & I \\
\hline $\mathrm{H}$ & pont-sib & Linaria genistifolia & . & . & . & . & + & + & . & . & . & . & . & $\mathbf{I}$ \\
\hline $\mathrm{H}$ & med & Plantago subulata & . & . & 1 & . & . & . & . & . & . & . & . & I \\
\hline $\mathrm{Th}$ & submed & Xeranthemum annuum & . & $\mathrm{r}$ & . & . & . & . & . & . & . & . & . & $\mathbf{I}$ \\
\hline $\mathrm{H}$ & pont-med & Stipa capillata & . & . & . & . & . & . & . & . & $\mathrm{r}$ & . & . & I \\
\hline & & Festuco-Brometea & & & & & & & & & & & & \\
\hline $\mathrm{H}$ & submed & Thymus striatus & + & . & $2 \mathrm{a}$ & + & 1 & + & $2 \mathrm{a}$ & $2 \mathrm{a}$ & + & $2 \mathrm{a}$ & $2 \mathrm{a}$ & $\mathbf{V}$ \\
\hline $\mathrm{H}$ & pont-med & Eryngium campestre & . & + & + & . & + & 1 & 1 & + & + & . & + & IV \\
\hline Th & pont-med & Petrorhagia prolifera & + & + & . & + & + & . & + & . & + & + & + & IV \\
\hline $\mathrm{H}$ & $\operatorname{cosm}$ & Plantago lanceolata & . & + & $2 \mathrm{a}$ & 1 & + & . & 1 & . & + & + & + & IV \\
\hline $\mathrm{H}$ & eur-as & Galium verum & $2 \mathrm{a}$ & $2 \mathrm{a}$ & . & $2 b$ & + & . & 1 & + & $2 \mathrm{a}$ & . & . & IV \\
\hline $\mathrm{H}$ & submed & Achillea setacea & + & 1 & . & . & . & . & + & + & + & . & . & III \\
\hline $\mathrm{H}$ & bal & Achillea clypeolata & . & . & . & 1 & 1 & . & . & . & . & . & . & $\mathbf{I}$ \\
\hline $\mathrm{H}$ & submed & Centaurea rhenana & . & . & $\mathrm{r}$ & . & . & . & . & . & . & . & . & $\mathbf{I}$ \\
\hline Th & submed & Xeranthemum cylindraceum & 1 & . & . & . & . & + & . & . & . & . & . & $\mathbf{I}$ \\
\hline $\mathrm{H}$ & bal-anat & Scabiosa argentea & . & . & . & . & + & . & . & . & . & . & . & $\mathbf{I}$ \\
\hline $\mathrm{H}$ & pann-bal & Achillea crithmifolia & . & . & + & . & . & . & . & . & . & . & . & I \\
\hline Th & eur-med & Alyssum desertorum & + & . & . & . & . & . & . & . & . & . & . & $\mathbf{I}$ \\
\hline $\mathrm{Th}$ & submed & Alyssum hirsutum & . & + & . & + & . & . & . & . & . & . & . & I \\
\hline $\mathrm{K}$ & med & Allium flavum & . & . & . & . & . & . & . & . & $\mathrm{r}$ & . & . & $\mathbf{I}$ \\
\hline $\mathrm{H}$ & pont & Convolvulus cantabrica & . & . & . & . & . & . & . & . & . & + & . & I \\
\hline $\mathrm{H}$ & $\operatorname{cosm}$ & Hypericum perforatum & . & . & . & . & . & . & . & . & + & . & . & $\mathbf{I}$ \\
\hline $\mathrm{H}$ & eur & Erysimum diffusum & . & . & . & . & . & . & . & . & . & $\mathrm{r}$ & . & $\mathbf{I}$ \\
\hline & & Koelerio-Corynephoretea & & & & & & & & & & & & \\
\hline $\mathrm{Th}$ & eur-sib & Trifolium arvense & . & . & + & + & + & + & + & . & $\mathrm{r}$ & 1 & 1 & IV \\
\hline $\mathrm{H}$ & eur-as & Poa bulbosa & . & . & 1 & . & 1 & + & + & . & $2 \mathrm{a}$ & $2 \mathrm{a}$ & + & IV \\
\hline
\end{tabular}




\begin{tabular}{|c|c|c|c|c|c|c|c|c|c|c|c|c|c|c|}
\hline & & No. of relevé & 1 & 2 & 3 & 4 & 5 & 6 & 7 & 8 & 9 & 10 & 11 & \\
\hline Th & eur-as & Arenaria leptoclados & + & . & + & + & + & + & + & . & + & . & . & IV \\
\hline Th & eur-med & Trifolium campestre & . & . & . & 1 & + & . & + & . & + & + & 1 & III \\
\hline Th & eur-as & Taeniatherum caput-medusae & + & + & . & + & + & . & + & . & . & . & . & III \\
\hline Th & med-as & Trifolium scabrum & . & . & . & + & + & + & . & + & . & . & . & II \\
\hline $\mathrm{H}$ & eur-submed & Rumex acetosella & . & . & . & + & + & . & + & . & . & . & + & II \\
\hline $\mathrm{H}$ & eur-med & Scleranthus perennis & . & . & . & . & + & + & . & . & . & . & 1 & II \\
\hline Th & eur-med & Trifolium striatum & . & . & . & + & . & . & + & . & . & . & + & II \\
\hline Th & subboreal & Erodium cicutarium & . & . & . & . & $\mathrm{r}$ & + & + & . & . & . & . & II \\
\hline Th & submed & Anthemis ruthenica & . & . & $\mathrm{r}$ & . & . & . & + & . & $\mathrm{r}$ & . & . & I \\
\hline Th & pont-med & Centaurea diffusa & . & . & . & . & 1 & . & + & . & . & . & . & I \\
\hline $\mathrm{H}$ & cosm;temp & Ceratodon purpureus & . & . & . & . & . & + & . & . & . & . & + & I \\
\hline $\mathrm{H}$ & eur-as & Phleum phleoides & . & . & . & . & . & . & . & . & . & + & + & I \\
\hline Th & eur-sib & Veronica arvensis & & + & . & . & . & . & . & . & . & . & . & I \\
\hline Th & subboreal & Vulpia myurus & . & . & . & . & + & . & . & . & . & . & . & I \\
\hline Th & boreal & Filago lutescens & . & . & $\mathrm{r}$ & . & . & . & . & . & . & . & . & I \\
\hline Th & boreal & Bromus tectorum & . & + & . & . & . & . & . & . & . & . & . & I \\
\hline Th & submed & Scleranthus polycarpos & . & . & + & . & . & . & . & . & . & . & . & I \\
\hline Th & eur-med & Alyssum alyssoides & . & . & . & . & . & + & . & . & . & . & . & I \\
\hline Th & subboreal & Apera spica-venti & . & . & . & . & . & . & + & . & . & . & . & I \\
\hline $\mathrm{Th}$ & eur-as & Filago vulgaris & . & . & . & . & . & . & . & . & . & . & + & I \\
\hline \multirow[t]{2}{*}{$\mathrm{H}$} & cosm;temp & Syntrichia ruralis & . & . & . & . & + & . & . & . & . & . & . & I \\
\hline & & Other species & & & & & & & & & & & & \\
\hline Th & eur-as & Crepis setosa & + & . & + & . & . & . & + & $\mathrm{r}$ & . & . & + & III \\
\hline $\mathrm{H}$ & pont & Koeleria nitidula & . & + & + & . & + & . & . & . & $2 b$ & + & . & III \\
\hline Th & eur-med & Cerastium pumilum & + & + & . & . & + & . & + & . & . & . & + & III \\
\hline $\mathrm{H}$ & pont-Cas & (S) Elymus hispidus & . & + & . & . & . & . & . & . & $2 \mathrm{a}$ & + & + & II \\
\hline Th & submed & Bromus squarrosus & . & . & + & . & + & + & . & . & . & . & . & II \\
\hline $\mathrm{H}$ & eur-as & Potentilla inclinata & . & . & . & + & . & + & . & . & . & . & + & II \\
\hline $\mathrm{H}$ & $\operatorname{cosm}$ & Convolvulus arvensis & . & + & . & . & . & + & + & . & . & . & . & II \\
\hline Th & med & Trifolium retusum & . & . & $2 \mathrm{a}$ & + & + & . & . & . & . & . & . & II \\
\hline Th & pont-Cas & Galium tenuissimum & . & . & . & + & . & . & + & . & + & + & . & II \\
\hline $\mathrm{H}$ & eur-sib & Carex praecox & . & . & . & 1 & . & & + & . & $\mathrm{r}$ & $2 \mathrm{~m}$ & . & II \\
\hline Th & eur-as & Erysimum repandum & . & . & . & + & + & + & . & . & . & . & . & II \\
\hline Th & submed & Trifolium pallidum & + & . & . & + & + & . & . & . & . & . & . & II \\
\hline $\mathrm{H}$ & eur-as & Echium vulgare & . & . & $\mathrm{r}$ & $\mathrm{r}$ & . & . & . & . & $\mathrm{r}$ & $\mathrm{r}$ & . & II \\
\hline Th & med & Trifolium setiferum & 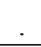 & & & 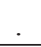 & & & . & + & + & + & . & I \\
\hline
\end{tabular}


Table 6: Relevés of the community of Chrysopogon gryllus.

Tabela 6: Popisi združbe Chrysopogon gryllus.

\begin{tabular}{|c|c|c|c|c|c|c|c|c|c|c|c|c|c|c|}
\hline \multirow{5}{*}{ 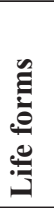 } & \multirow{5}{*}{ 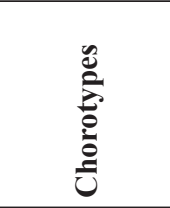 } & \multirow{5}{*}{$\begin{array}{l}\text { No. of relevé } \\
\text { altitude [m] } \\
\text { aspect } \\
\text { cover [\%] } \\
\text { number of species }\end{array}$} & \multirow{2}{*}{$\begin{array}{c}\mathbf{1} \\
179\end{array}$} & \multirow{2}{*}{$\begin{array}{c}2 \\
190\end{array}$} & \multirow{2}{*}{$\begin{array}{c}3 \\
165\end{array}$} & \multirow{2}{*}{$\begin{array}{c}4 \\
195\end{array}$} & 5 & \multirow{2}{*}{$\begin{array}{c}\mathbf{6} \\
165\end{array}$} & $\begin{array}{c}7 \\
191\end{array}$ & \multirow{2}{*}{8} & \multirow{2}{*}{$\begin{array}{c}9 \\
369\end{array}$} & 10 & \multicolumn{2}{|l|}{11} \\
\hline & & & & & & & 235 & & 191 & & & 316 & 315 & 3 \\
\hline & & & $\mathrm{S}$ & $\mathrm{N}$ & W & . & $\mathrm{NE}$ & . & NW & $\mathrm{N}$ & $\mathrm{N}$ & NW & $\mathrm{S}$ & Е \\
\hline & & & 100 & 100 & 95 & 95 & 100 & 100 & 95 & 100 & 100 & 95 & 85 & $\bar{\Xi}$ \\
\hline & & & 17 & 22 & 18 & 18 & 20 & 14 & 20 & 25 & 28 & 27 & 38 & U \\
\hline 1 & 2 & 3 & 4 & 5 & 6 & 7 & 8 & 9 & 10 & 11 & 12 & 13 & 14 & 15 \\
\hline $\mathrm{H}$ & pont-med & Chrysopogon gryllus & 5 & 4 & 3 & 3 & 3 & $2 \mathrm{a}$ & 4 & 1 & $2 b$ & + & 3 & $\mathbf{V}$ \\
\hline & & Festucion valesiacae & & & & & & & & & & & & \\
\hline $\mathrm{H}$ & pont-med & Eryngium campestre & $\mathrm{r}$ & + & + & 1 & + & 1 & + & + & + & + & + & $\mathbf{V}$ \\
\hline $\mathrm{H}$ & submed & Achillea setacea & + & . & + & + & + & . & + & . & + & + & . & IV \\
\hline $\mathrm{H}$ & pont-med & Festuca valesiaca & . & $2 \mathrm{a}$ & $2 b$ & . & 4 & . & + & $2 \mathrm{~m}$ & . & + & 1 & IV \\
\hline $\mathrm{H}$ & eur-med & Asperula cynanchica & . & + & + & . & . & . & . & . & . & $\mathrm{r}$ & . & II \\
\hline $\mathrm{H}$ & eur-as & Astragalus onobrychis & . & + & 1 & . & . & . & . & . & . & $2 \mathrm{a}$ & + & II \\
\hline $\mathrm{H}$ & bal-dac & Dianthus pallens & + & . & + & + & . & . & . & . & . & . & . & II \\
\hline $\mathrm{Th}$ & submed & Xeranthemum anпиит & . & . & . & . & . & . & . & . & . & . & + & $\mathbf{I}$ \\
\hline $\mathrm{H}$ & pont-sib & Linaria genistifolia & . & . & . & . & . & . & . & . & . & + & . & $\mathbf{I}$ \\
\hline $\mathrm{H}$ & pont-med & Stipa capillata & . & . & . & . & . & . & . & . & . & . & $2 \mathrm{a}$ & $\mathbf{I}$ \\
\hline $\mathrm{H}$ & pont-med & Teucrium polium & . & + & . & . & . & . & . & . & . & . & + & $\mathbf{I}$ \\
\hline $\mathrm{H}$ & smed-as & Dichanthium ischaemum & $\mathrm{r}$ & . & . & . & . & . & . & . & . & . & + & $\mathbf{I}$ \\
\hline $\mathrm{H}$ & bal-dac & Achillea clypeolata & . & $\mathrm{r}$ & . & . & . & . & . & . & . & . & 1 & $\mathbf{I}$ \\
\hline & & Festuco-Brometea & & & & & & & & & & & & \\
\hline $\mathrm{H}$ & eur-as & Galium verum & + & . & $2 \mathrm{a}$ & . & $2 b$ & + & + & + & + & + & . & IV \\
\hline $\mathrm{H}$ & submed & Thymus striatus & . & . & + & + & . & . & + & + & . & . & $2 \mathrm{a}$ & III \\
\hline $\mathrm{H}$ & $\operatorname{cosm}$ & Plantago lanceolata & . & . & + & . & . & . & + & + & + & + & . & III \\
\hline $\mathrm{H}$ & pont & Potentilla argentea & . & . & . & . & . & 1 & + & . & + & . & . & II \\
\hline $\mathrm{H}$ & subboreal & Sanguisorba minor & . & + & . & . & . & . & . & . & + & 1 & + & II \\
\hline Th & pont-med & Petrorhagia prolifera & + & . & + & . & . & . & . & . & . & . & + & II \\
\hline $\mathrm{H}$ & subboreal & Potentilla neglecta & . & . & . & . & . & . & . & 1 & . & . & . & $\mathbf{I}$ \\
\hline $\mathrm{Th}$ & submed & Xeranthemum cylindraceum & . & . & . & + & . & + & . & . & . & . & . & I \\
\hline $\mathrm{H}$ & eur-sib & Chondrilla juncea & . & . & . & . & . & . & . & . & + & . & . & $\mathbf{I}$ \\
\hline $\mathrm{H}$ & eur-submed & Melica ciliata & $\mathrm{r}$ & . & . & . & . & . & . & . & . & . & . & $\mathbf{I}$ \\
\hline $\mathrm{H}$ & pont & Convolvulus cantabrica & . & + & . & . & . & . & . & . & . & . & + & $\mathbf{I}$ \\
\hline $\mathrm{H}$ & submed & Centaurea rhenana & . & + & . & . & . & . & . & . & . & . & . & $\mathbf{I}$ \\
\hline & & Other species & & & & & & & & & & & & \\
\hline $\mathrm{Th}$ & eur-as & Crepis setosa & . & . & + & . & + & + & 1 & + & + & . & + & IV \\
\hline Th & eur-as & Taeniatherum caput-medusae & + & . & . & + & $2 \mathrm{~m}$ & . & . & . & + & + & . & III \\
\hline $\mathrm{H}$ & eur-as & Dactylis glomerata & . & . & . & $2 \mathrm{a}$ & + & . & . & 3 & $2 \mathrm{a}$ & . & . & II \\
\hline $\mathrm{H}$ & eur-med & Lotus corniculatus & . & . & . & $\mathrm{r}$ & + & . & . & . & + & $2 \mathrm{a}$ & . & II \\
\hline $\mathrm{H}$ & eur-submed & Rumex acetosella & . & . & . & . & . & . & + & + & + & . & . & II \\
\hline Th & eur-med & Trifolium striatum & . & . & + & . & $2 \mathrm{a}$ & + & . & 3 & . & . & . & II \\
\hline $\mathrm{H}$ & eur-as & Lolium perenne & . & . & . & + & + & . & . & + & . & $2 \mathrm{~m}$ & . & II \\
\hline $\mathrm{K}$ & pont-submed & Ornithogalum umbellatum & . & + & . & . & . & . & . & + & $\mathrm{r}$ & . & . & II \\
\hline Th & eur-med & Trifolium campestre & . & . & 1 & . & + & . & . & . & . & + & 1 & II \\
\hline $\mathrm{H}$ & eur-as & Potentilla inclinata & . & + & . & + & + & . & + & . & . & . & . & II \\
\hline Th & eur-med & Cerastium pumilum & . & . & . & . & + & . & + & + & . & . & . & II \\
\hline $\mathrm{H}$ & eur-med & Carduus nutans & . & . & $\mathrm{r}$ & . & . & . & $\mathrm{r}$ & . & . & $\mathrm{r}$ & . & II \\
\hline $\mathrm{H}$ & eur-as & Poa bulbosa & . & + & . & . & . & . & . & + & . & $2 \mathrm{a}$ & 1 & II \\
\hline $\mathrm{H}$ & pont & Koeleria nitidula & . & + & . & . & . & . & . & 1 & . & . & + & II \\
\hline Th & eur-as & Aegilops triuncialis & + & $2 \mathrm{~m}$ & . & . & . & . & . & . & . & $2 \mathrm{~m}$ & . & II \\
\hline Th & med & Trifolium angustifolium & . & + & + & . & 1 & . & . & . & . & . & . & II \\
\hline
\end{tabular}




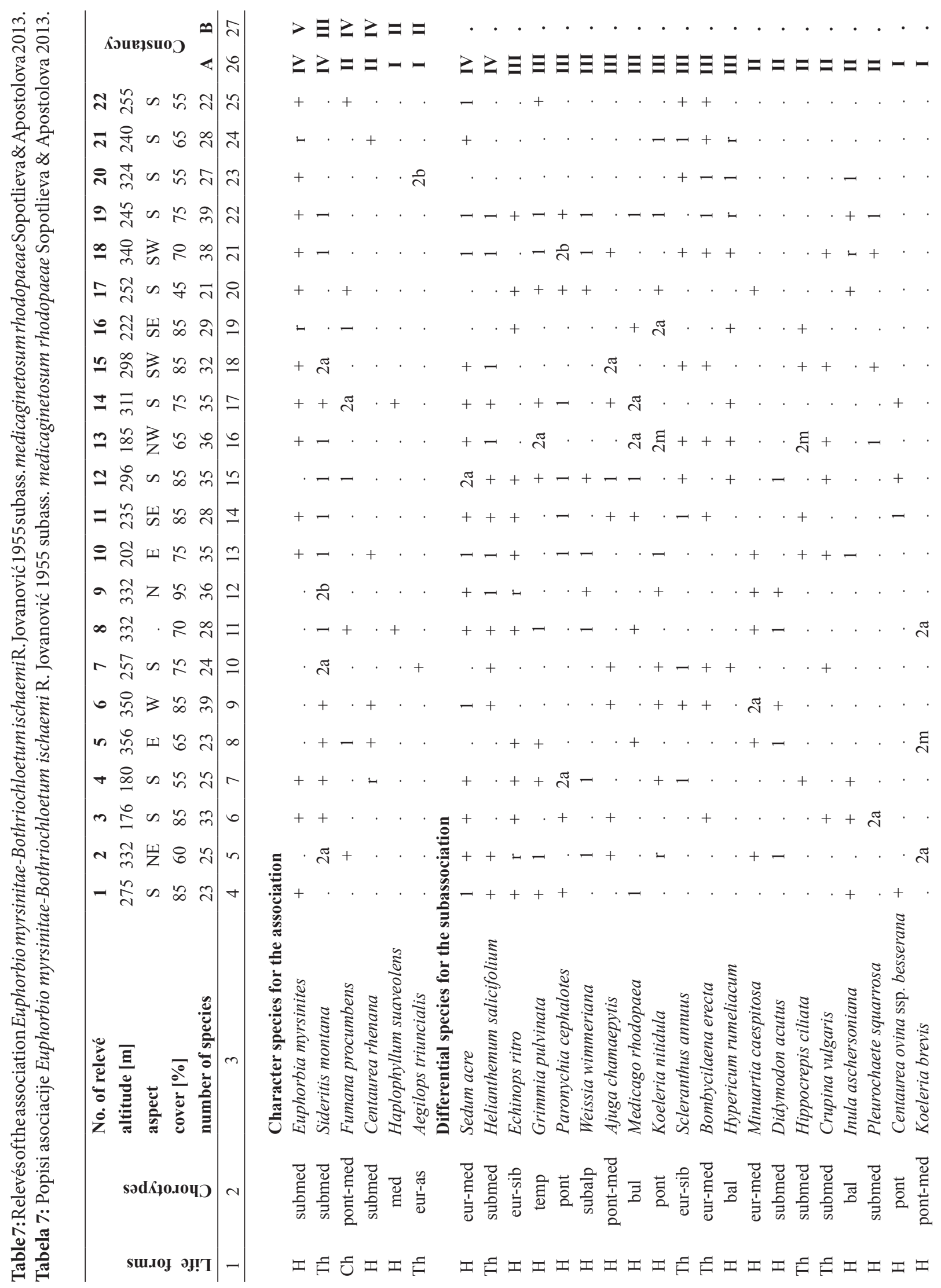




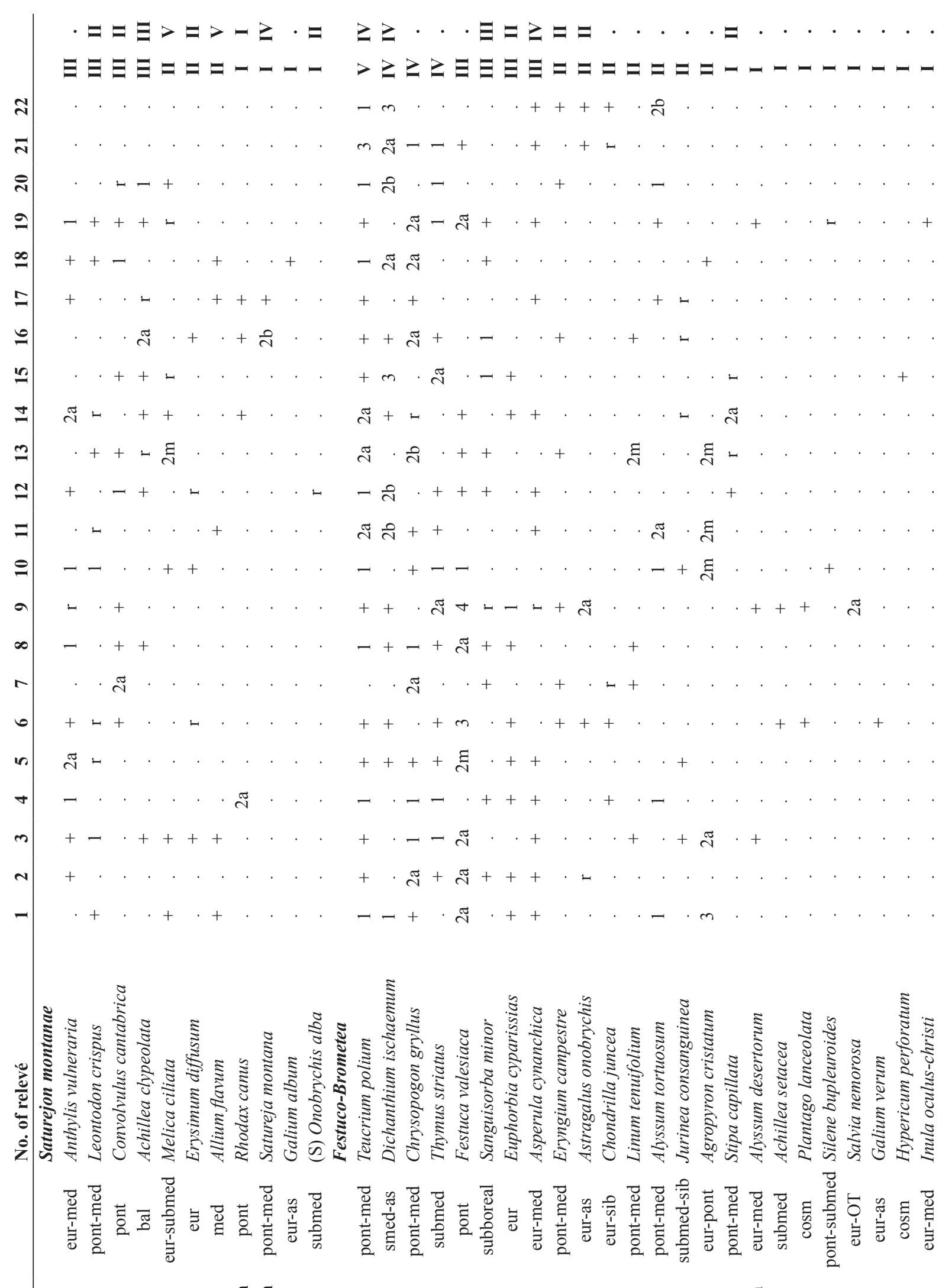

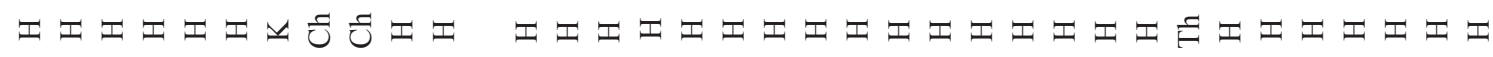




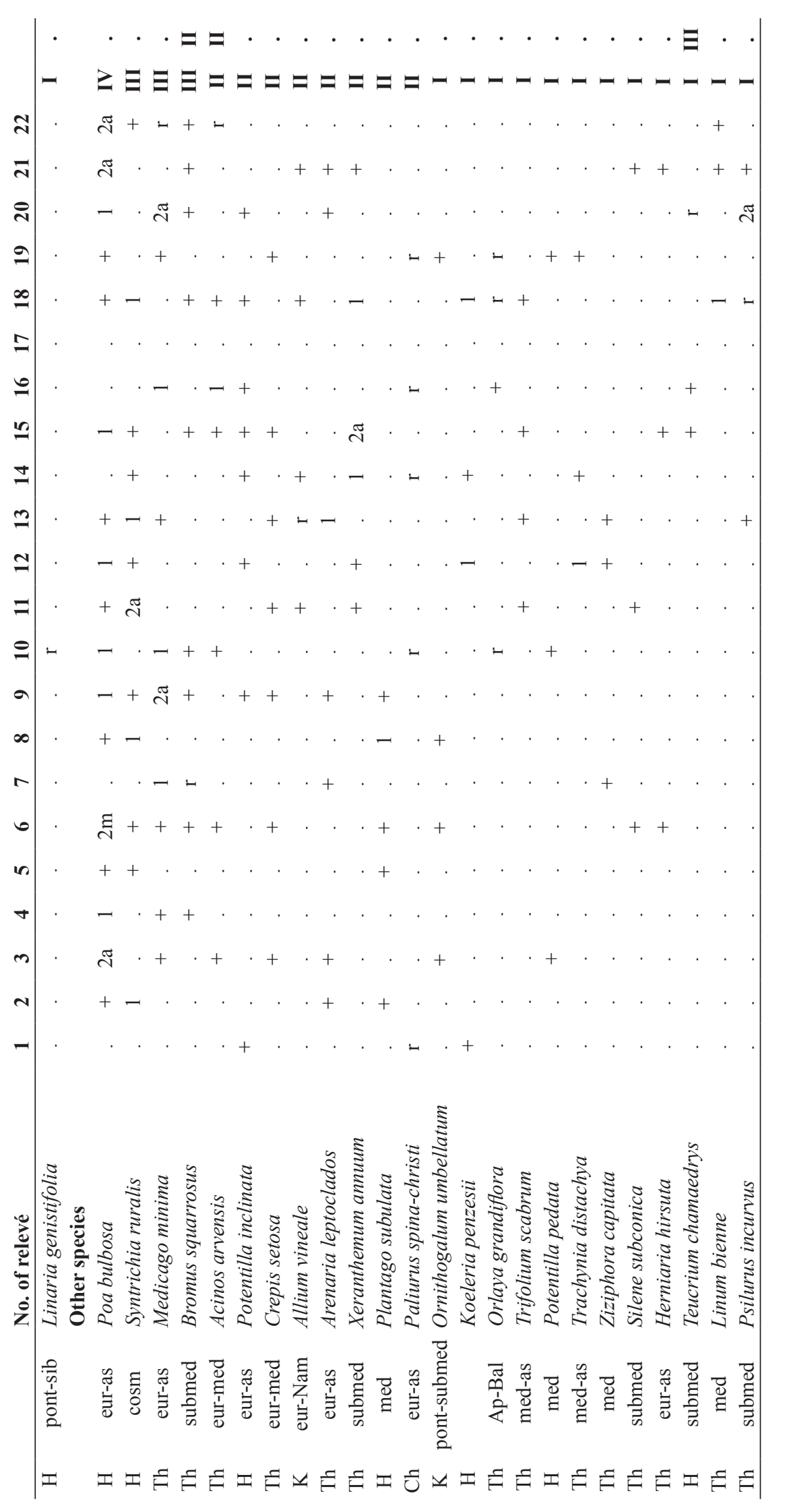


Table 8: Relevés of the association Vulpietum myuri Philippi 1973.

Tabela 8: Popisi asociacije Vulpietum myuri Philippi 1973.

Localities: 1. E from Zlatari village, 29. 06. 2004; 2. Lozitsa village, 42.72499 N, 26.77974 E, 26. 06. 2005; 3. E from Devetak village, 42.57002 N, 26.84377 E, 23. 06. 2005.

\begin{tabular}{|c|c|c|c|c|c|c|}
\hline \multirow{5}{*}{ 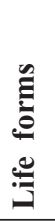 } & \multirow{5}{*}{ 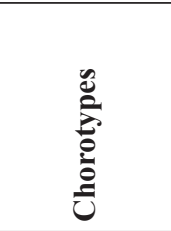 } & No. of relevé & 1 & 2 & 3 & \multirow{5}{*}{ 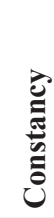 } \\
\hline & & altitude $[\mathrm{m}]$ & 268 & 203 & 230 & \\
\hline & & aspect & $\mathrm{E}$ & $\mathrm{NE}$ & $\mathrm{W}$ & \\
\hline & & cover $[\%]$ & 95 & 95 & 90 & \\
\hline & & number of species & 13 & 13 & 20 & \\
\hline \multirow[t]{2}{*}{1} & 2 & 3 & 4 & 5 & 6 & 7 \\
\hline & & \multicolumn{5}{|c|}{ Character species for the association, Thero-Airion } \\
\hline Th & subboreal & Vulpia myurus & 5 & 4 & 3 & $\mathbf{V}$ \\
\hline Th & eur-as & Filago vulgaris & . & + & . & II \\
\hline $\mathrm{H}$ & submed & Dasypyrum villosum & . & . & + & II \\
\hline $\mathrm{H}$ & eur-med & Scleranthus perennis & . & . & $2 b$ & II \\
\hline $\mathrm{H}$ & pont & Potentilla argentea & + & . & . & II \\
\hline \multirow[t]{2}{*}{ Th } & eur-med & Trifolium striatum & . & . & + & II \\
\hline & & Koelerio-Corynephoretea & & & & \\
\hline $\mathrm{H}$ & eur-as & Poa bulbosa & + & . & $2 b$ & IV \\
\hline Th & subboreal & Apera spica-venti & 1 & $2 \mathrm{~m}$ & . & IV \\
\hline $\mathrm{H}$ & pont-med & Centaurea diffusa & . & $\mathrm{r}$ & . & II \\
\hline $\mathrm{H}$ & eur-submed & Rumex acetosella & 1 & . & . & II \\
\hline \multirow[t]{2}{*}{ Th } & eur-as & Arenaria leptoclados & . & . & 1 & II \\
\hline & & Other species & & & & \\
\hline Th & eur-as & Crepis setosa & $\mathrm{r}$ & $2 \mathrm{a}$ & + & $\mathbf{V}$ \\
\hline Th & eur-as & Taeniatherum caput-medusae & 1 & + & . & IV \\
\hline $\mathrm{H}$ & pont-med & Eryngium campestre & + & . & + & IV \\
\hline $\mathrm{H}$ & eur-as & Anthoxanthum odoratum & + & . & . & II \\
\hline $\mathrm{H}$ & eur-med & Hypochaeris radicata & + & . & . & II \\
\hline $\mathrm{H}$ & eur-sib & Chondrilla juncea & + & . & . & II \\
\hline $\mathrm{H}$ & submed & Cynosurus echinatus & + & . & . & II \\
\hline $\mathrm{Ch}$ & submed & Rosa canina & + & . & . & II \\
\hline Th & eur-as & Bromus arvensis & . & + & . & II \\
\hline Th & eur-as & Daucus carota & . & + & . & II \\
\hline $\mathrm{H}$ & eur-as & Cirsium arvense & . & $\mathrm{r}$ & . & II \\
\hline $\mathrm{H}$ & eur-as & Lolium perenne & . & $2 \mathrm{~m}$ & . & II \\
\hline $\mathrm{H}$ & & Pohlia sp. & . & + & . & II \\
\hline Th & eur-med & Centaurea cyanus & . & $\mathrm{r}$ & . & II \\
\hline $\mathrm{H}$ & cosm & Convolvulus arvensis & . & + & . & II \\
\hline $\mathrm{H}$ & smed-as & Dichanthium ischaemum & . & . & + & II \\
\hline Th & bal & Centaurea caliacrae & . & . & + & II \\
\hline Th & pont-med & Petrorhagia prolifera & . & . & + & II \\
\hline $\mathrm{H}$ & submed & Thymus striatus & . & . & $2 a$ & II \\
\hline Th & submed & Psilurus incurvus & . & . & + & II \\
\hline Th & med & Trifolium angustifolium & . & . & + & II \\
\hline $\mathrm{H}$ & $\operatorname{cosm}$ & Plantago lanceolata & . & . & + & II \\
\hline Th & eur-as & Aegilops triuncialis & . & . & + & II \\
\hline $\mathrm{H}$ & eur-med & Carduus nutans & . & . & + & II \\
\hline $\mathrm{H}$ & eur-med & Trifolium hybridum & . & . & 1 & II \\
\hline $\mathrm{H}$ & submed & (S) Onobrychis alba & . & . & 1 & II \\
\hline Th & submed & Bromus squarrosus & & . & + & II \\
\hline
\end{tabular}


Table 9: Ecological characteristics of the ten dry-grassland vegetation types. Means and standard deviations are given. Different letters indicate significant differences between communities at $\alpha=0.05$ from Tukey's HSD test; $p$-values derived from ANOVAs. Abreviations are as in Figure 3.

Tabela 9: Ekološke značilnosti desetih vegetacijskih tipov suhih travišč. Prikazana so povprečja in standardni odkloni. Različne črke kažejo statistično značilne razlike med združbami pri $\alpha=0,05 \mathrm{v}$ Tukeyevem HSD testu; p vrednosti so dobljene z testom ANOVA. Okrajšave so kot na sliki 3.

\begin{tabular}{|c|c|c|c|c|c|c|c|c|c|c|c|}
\hline & 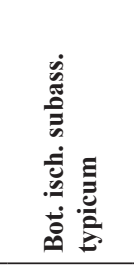 & 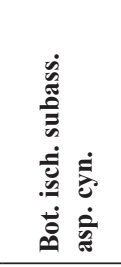 & 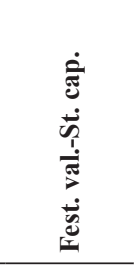 & 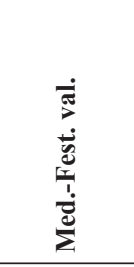 & 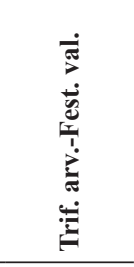 & 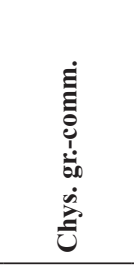 & 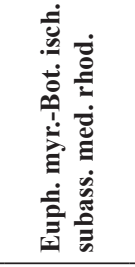 & 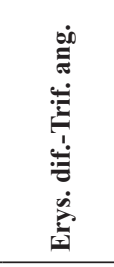 & 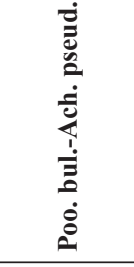 & 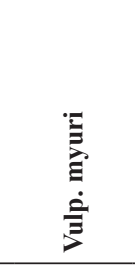 & $p$ \\
\hline Number of relevés & 33 & 48 & 11 & 12 & 11 & 11 & 22 & 18 & 7 & 3 & \\
\hline Altitude [m] & $213 \pm 64^{a}$ & $222 \pm 56^{\mathrm{a}}$ & $241 \pm 61^{\mathrm{abc}}$ & $221 \pm 56^{\mathrm{ab}}$ & $262 \pm 66^{\mathrm{abc}}$ & $223 \pm 77^{\mathrm{abc}}$ & $273 \pm 58^{\mathrm{bc}}$ & $294 \pm 39^{c}$ & $242 \pm 88^{\mathrm{abc}}$ & $234 \pm 33^{\mathrm{abc}}$ & $<0.001$ \\
\hline Slope $\left[^{\circ}\right]$ & $8 \pm 6^{a}$ & $11 \pm 7^{\mathrm{a}}$ & $13 \pm 8^{\mathrm{ab}}$ & $12 \pm 6^{\mathrm{ab}}$ & $11 \pm 7^{\mathrm{ab}}$ & $9 \pm 8^{\mathrm{a}}$ & $18 \pm 8^{b}$ & $7 \pm 6^{\mathrm{a}}$ & $13 \pm 5^{\mathrm{ab}}$ & $10 \pm 8^{\mathrm{ab}}$ & $<0.001$ \\
\hline $\begin{array}{l}\text { Species richness } \\
\text { [number] }\end{array}$ & $23.5 \pm 4.8^{\mathrm{ab}}$ & $24.0 \pm 6.0^{\mathrm{abb}}$ & $24.0 \pm 7.5^{\mathrm{abc}}$ & $24.8 \pm 3.4^{\text {abcd }}$ & $28.9 \pm 5.9^{\text {bcd }}$ & $22.5 \pm 6.7^{\mathrm{ab}}$ & $30.0 \pm 5.9^{\mathrm{cd}}$ & $31.4 \pm 5.6^{\mathrm{d}}$ & $24.6 \pm 5.3^{\mathrm{abcd}}$ & d $15.3 \pm 4.0^{\mathrm{a}}$ & $<0.001$ \\
\hline Total cover [\%] & $90 \pm 8^{\mathrm{a}}$ & $88 \pm 8^{\mathrm{ab}}$ & $77 \pm 13^{\text {cd }}$ & $88 \pm 7^{\mathrm{abc}}$ & $90 \pm 4^{\mathrm{ab}}$ & $97 \pm 5^{\mathrm{a}}$ & $73 \pm 13^{d}$ & $87 \pm 7^{\mathrm{abc}}$ & $77 \pm 11^{\text {bcd }}$ & $93 \pm 3^{\text {abc }}$ & $<0.001$ \\
\hline
\end{tabular}

Table 10: Percentage of chorotypes and main life forms in the species composition of the nine studied plant associations. Abreviations are as in Figure 3.

Table 10: Odstotek horotipov in glavnih življenskih oblik v vrstni sestavi devetih proučevanih rastlinskih asociacijah. Okrajšave so kot na sliki 3.

\begin{tabular}{|c|c|c|c|c|c|c|c|c|c|}
\hline & Bot. isch. & $\begin{array}{c}\text { Fest. val.- } \\
\text { St. cap. }\end{array}$ & $\begin{array}{c}\text { Med.- } \\
\text { Fest. val. }\end{array}$ & $\begin{array}{l}\text { Trif. arv.- } \\
\text { Fest. val. }\end{array}$ & $\begin{array}{c}\text { Chys. gr.- } \\
\text { comm. }\end{array}$ & $\begin{array}{c}\text { Euph. myr.- } \\
\text { Bot. isch. } \\
\text { subass. } \\
\text { med. rhod. }\end{array}$ & $\begin{array}{c}\text { Erys. } \\
\text { dif.-Trif. } \\
\text { ang. }\end{array}$ & $\begin{array}{c}\text { Poo. } \\
\text { bul.-Ach. } \\
\text { pseud. }\end{array}$ & $\begin{array}{l}\text { Vulp. } \\
\text { myuri }\end{array}$ \\
\hline Number of relevés & 81 & 11 & 12 & 11 & 11 & 22 & 18 & 7 & 3 \\
\hline Total no. of species & 239 & 113 & 109 & 124 & 124 & 130 & 161 & 77 & 38 \\
\hline \multicolumn{10}{|l|}{ Chorotypes } \\
\hline Adv & $0.8 \%$ & $1.8 \%$ & $0.9 \%$ & $0.8 \%$ & $0.8 \%$ & - & - & - & - \\
\hline Alp & $0.8 \%$ & - & $0.9 \%$ & - & $0.8 \%$ & $0.8 \%$ & $0.6 \%$ & - & - \\
\hline Bal & $6.1 \%$ & $6.2 \%$ & $5.5 \%$ & $6.5 \%$ & $4.8 \%$ & $10.0 \%$ & $5.6 \%$ & $9.1 \%$ & $2.6 \%$ \\
\hline Boreal & $5.9 \%$ & $8.9 \%$ & $6.4 \%$ & $7.3 \%$ & $6.5 \%$ & $2.3 \%$ & $6.2 \%$ & $11.7 \%$ & $5.3 \%$ \\
\hline Bul & - & - & - & - & - & $0.8 \%$ & - & - & - \\
\hline Cosm & $4.6 \%$ & $4.4 \%$ & $4.6 \%$ & $5.7 \%$ & $5.7 \%$ & $2.3 \%$ & $3.7 \%$ & $6.5 \%$ & $5.3 \%$ \\
\hline Eur & $19.3 \%$ & $15.0 \%$ & $17.4 \%$ & $19.4 \%$ & $18.6 \%$ & $15.4 \%$ & $18.6 \%$ & $13.0 \%$ & $18.4 \%$ \\
\hline Eur-As & $25.5 \%$ & $21.2 \%$ & $16.5 \%$ & $24.2 \%$ & $27.4 \%$ & $20.0 \%$ & $23.0 \%$ & $22.1 \%$ & $34.2 \%$ \\
\hline Med & $23.9 \%$ & $27.4 \%$ & $33.0 \%$ & $20.2 \%$ & $19.4 \%$ & $27.7 \%$ & $29.8 \%$ & $20.8 \%$ & $21.1 \%$ \\
\hline Pont & $9.6 \%$ & $14.2 \%$ & $12.8 \%$ & $13.7 \%$ & $15.3 \%$ & $18.5 \%$ & $10.6 \%$ & $16.9 \%$ & $10.5 \%$ \\
\hline Unknown & $2.9 \%$ & $0.9 \%$ & $1.8 \%$ & $2.4 \%$ & $0.8 \%$ & $2.3 \%$ & $1.9 \%$ & - & $2.6 \%$ \\
\hline \multicolumn{10}{|l|}{ Life forms } \\
\hline Hemicryptophytes & $50.2 \%$ & $46.9 \%$ & $55.1 \%$ & $54.0 \%$ & $58.0 \%$ & $63.9 \%$ & $54.0 \%$ & $50.1 \%$ & $55.3 \%$ \\
\hline Therophytes & $46.4 \%$ & $49.5 \%$ & $43.1 \%$ & $41.9 \%$ & $37.9 \%$ & $28.5 \%$ & $42.2 \%$ & $46.8 \%$ & $42.1 \%$ \\
\hline
\end{tabular}




\section{APPENDIX}

Table 2: Relevés of the association Bothriochloetum ischaemi (Krist. 1937) I. Pop 1977.

Species occurring in $\mathbf{2}$ or fewer relevés: Chamomilla recutita (Th, Eur-As, 13:+, 43:+); Verbascum banaticum (H, Bal-Dac, 4:+, 60:r); Tribulus terrestris (Th, EurAs, 1:+, 55:+); Consolida regalis (Th, Eur-Med, 22:+, 75:+); Goniolimon collinum (H, Pont, 1:r); Myosotis stricta (Th, Eur-As, 12:+, 51:+); Lathyrus nissolia (Th, Eur-sMed, 22:+, 75:+); Trifolium hybridum (H, EurMed, 16:2a, 60:2a); Matricaria trichophylla (Th, Med, 75:+, 76:+); Crepis sancta (Th, subMed, 10:r); Plantago major $(\mathrm{H}$, Boreal, 17:r); Achillea clypeolata (H, Bal, 12:+); Astracantha thracica (Ch, Bal, 13:r); (S) Vicia pannonica (Th, Eur-Med, 26:r); Trifolium suffocatum (Th, subMed, 3:+); Homalothecium lutescens (H, 30:3); Achillea nobilis (H, Eur-As, 1:2b); Silene conica (Th, subMed-As, 12:+); Verbascum xanthophoeniceum $(\mathrm{H}$, Bal-Anat, 16:r); Sisymbrium orientale (Th, Eur-As, 8:r); Galium verticillatum (Th, Med-As, 4:+); Falcaria vulgaris (H, Eur-As, 29:+); Tragopogon pratensis $(\mathrm{H}$, Eur-Med, 21:r, 28:+); Geranium molle (H, Eur-Med, 20:+, 31:+); Bromus scoparius (Th, subMed, 14:+, 17:+); Carex spicata (H, Eur-As, 12:+, 23:+); Coronilla varia (H, Eur-Med, 6:1); Centaurea calcitrapa (H, Med, 9:+); Melilotus officinalis (Th, Eur-As, 17:r); Scorzonera hispanica (H, Med, 9:+); Trifolium aureum (Th, EurSib, 60:+, 65:+); Koeleria simonkaii (H, Bal, 44:1, 63:2a); Leontodon crispus (H, Pont-Med, 35:r); Tragopogon orientalis (H, Eur-Med, 53:r, 69:r); Dianthus moesiacus (H, Bal, 40:+); Crucianella angustifolia (Th, Med, 46:+, 69:+); Trigonella monspeliaca (Th, subMed, 56:r, 64:+); Bupleurum apiculatum (Th, Bal, 46:+, 80:+); Ziziphora capitata (Th, Med, 61:+); Geranium pusillum (Th, EurMed, 43:r); Sedum hispanicum (H, Eur-Med, 51:1); Onobrychis caput-gali (Th, subMed, 65:3); Plantago lagopus (Th, Med, 35:r); Trifolium affine (Th, BalAnat, 64:1); Bryum elegans (H, 45:+); Scorzonera lanata (H, Med, 47:+); Dianthus roseoluteus (H, Pont-Sib, 50:+); Dianthus pinifolius (H, Bal-dac, 59:+); Phascum cuspidatum (H, umeren, 45:+); Cerastium dubium (Th, Eur, 61:+); Poa pratensis (H, cosm, 68:+); (S) Onobrychis alba (H, subMed, 48:1); Crupina vulgaris (Th, subMed, 69:+); Lathyrus aphaca (Th, subBoreal, 72:1); Caucalis platicarpos (Th, Eur-CAs, 76:r); Alopecurus pratensis (H, Eur-As, 75:+); Ornithogalum narbonense (K, Med, 33:+); Rosa canina (Ch, subMed, 52:r); Cardaria draba (H, Eur-Med, 71:1); Valerianella sp. (69:+); Veronica polita (Th, Eur-As, 78:+); Stachys germanica (H, EursubMed, 48:+, 50:+); Galium album (H, Eur-As, 73:+); Ajuga genevensis (H, Pont, 76:+); Odontites serotina (Th,
Eur, 57:+); Myosotis sp. (69:+); Dorycnium herbaceum (H, Eur-Med, 52:2a); Geranium dissectum (Th, Eur-As, 76:r); Eurhynchium hians (H, 33:+); Orlaya grandiflora (Th, Ap-Bal, 46:+); Paliurus spina-christi (Ch, Eur-As, 46:r); Ranunculus sardous (Th, Eur-Med, 68:+); Vicia cracca (H, Eur-As, 52:+); Agrostis canina (H, EurSib, 68:+); Medicago orbicularis (Th, Eur-Med, 34:+); Echinops ritro (H, Eur-Sib, 67:+); Alyssum tortuosum (H, Pont-Med, 13:+); Stipa capillata (H, Pont-Med, 50:1, 59:r); Allium flavum (K, Med, 47:r); Phleum phleoides (H, Eur-As, 36:+); (S) Hieracium praealtum (H, 48:+, 60:1); Fragaria viridis (H, Eur-Sib, 41:+,46:+); Alyssum alyssoides (Th, Eur-Med, 51:+); Ventenata dubia (Th, Pont-Med, 60:r); Hordeum bulbosum (H, Eur-As, 24:+, 53:2a); Trifolium cherleri (H, Med, 1:+); Vicia grandiflora (H, subMed, 72: +, 75:+); Scleranthus annuus (Th, EurSib, 39:+, 64:r).

Localities: 1. Dalak Chalabair loc., NE from Kermen, 42.51339 ${ }^{\circ} \mathrm{N}, 26.28025^{\circ} \mathrm{E}, 18.07 .2004 ; 2$. Chukarka village, Burgas distr., $42.64371^{\circ} \mathrm{N}, 27.11221^{\circ}$ E, 13.07.2005; 3. S from Zlati vojvoda village, Sliven distr., $42.57842^{\circ} \mathrm{N}, 26.18539^{\circ} \mathrm{E}, 18.07 .2004 ;$ 4. S from Tenevo village, Yambol distr., $42.33451^{\circ} \mathrm{N}, 26.54058^{\circ}$ E, 11.06.2004; 5. S from Vodenichane village, Yambol distr., $42.53231^{\circ} \mathrm{N}, 26.69298^{\circ} \mathrm{E}, 02.07 .2005 ; 6$. By the road Yambol-Elhovo, $\mathrm{S}$ from cross-road to Tenevo village, Yambol distr., $42.35561^{\circ} \mathrm{N}, 26.57036^{\circ} \mathrm{E}$, 15.07.2004; 7. NE from Ovchi kladenets village, Yambol distr., $42.23864^{\circ} \mathrm{N}, 26.20544^{\circ} \mathrm{E}, 21.07 .2004$; 8. E from Rechitsa, Sliven, $42.62945^{\circ} \mathrm{N}, 26.28969^{\circ}$ E, 03.06.2004; 9. NW from Rosa village, Yambol distr., $42.42406^{\circ} \mathrm{N}, 26.40272^{\circ} \mathrm{E}, 16.07 .2004 ; 10$. between Kozarevo and Kalchevo villages, Yambol dist., $42.44173^{\circ} \mathrm{N}, 26.59862^{\circ} \mathrm{E}, 30.06 .2004$; 11. NE from Krushovo village, Burgas distr., $42.55444^{\circ} \mathrm{N}$, $27.07307^{\circ} \mathrm{E}, 11.07 .2005 ; 12$. E from Izvorishte village, Burgas distr., $42.66028^{\circ} \mathrm{N}, 27.43617^{\circ} \mathrm{E}, 21.07 .2005 ; 13$. E from Kozarevo, Tvarditsa, Sliven distr., $42.46031^{\circ} \mathrm{N}$, $26.62372^{\circ} \mathrm{E}, 30.06 .2004 ; 14$. S from Troyanovo village, Burgas distr., $42.54496^{\circ} \mathrm{N}, 27.14339^{\circ} \mathrm{E}, 11.07 .2005$; 15. between Kozarevo and Kalchevo villages, Yambol dist., 30.06.2004; 16. hill between Chokoba and Bezmer villages, Yambol distr., 09.06.2004; 17. E from Zheleznik village, Burgas distr., $42.56714^{\circ} \mathrm{N}$, $26.91149^{\circ}$ E, 02.07.2005; 18. S from Karnobat, Burgas distr., $42.62547^{\circ} \mathrm{N}, 26.98660^{\circ} \mathrm{E}, 29.06 .2005 ; 19$. S from Smolnik village, Burgas distr., $42.52488^{\circ} \mathrm{N}, 26.92806^{\circ}$ $\mathrm{E}, 05.07 .2005 ; 20$. NW from Irechekovo village, Yambol distr., $42.49553^{\circ} \mathrm{N}, 26.72015^{\circ} \mathrm{E}, 17.06 .2005$; 21. between Ekzarh Antimovo and Zhitosvyat villages, Burgas distr., $42.48860^{\circ} \mathrm{N}, 26.97875^{\circ} \mathrm{E}, 05.07 .2005 ; 22$. Maglen village, Burgas distr., $42.73323^{\circ} \mathrm{N}, 27.36793^{\circ} \mathrm{E}$, 22.07.2005; 23. Golemiya bair loc., NW from Irechekovo 
village, Yambol distr., $42.49116^{\circ} \mathrm{N}, 26.74852^{\circ} \mathrm{E}$, 17.06.2005; 24. NW from Voynika village, Yambol distr., 01.07.2004; 25. W from Detelina village, Burgas distr., $42.56347^{\circ} \mathrm{N}, 27.02275^{\circ} \mathrm{E}, 11.07 .2005$; 26. NW from Karnobat, Burgas distr., $42.63651^{\circ} \mathrm{N}, 26.94968^{\circ}$ E, 29.06.2005; 27. S from Krumovo gradishte village, Burgas distr., $42.60185^{\circ} \mathrm{N}, 26.93290^{\circ} \mathrm{E}, 29.06 .2005$; 28. between Ekzarh Antimovo and Zhitosvyat villages, Burgas distr., $42.49419^{\circ} \mathrm{N}, 26.97703^{\circ} \mathrm{E}, 05.07 .2005$; 29. between Sadievo and Dryankovets villages, Burgas distr., $42.67682^{\circ} \mathrm{N}, 27.32084^{\circ} \mathrm{E}, 22.07 .2005$; 30. S from Parvenets village, Yambol distr., $42.41991^{\circ} \mathrm{N}$, $26.85475^{\circ} \mathrm{E}, 02.07 .2005$; 31. Golemiya bair loc., NW from Irechekovo village, Yambol distr., $42.49173^{\circ} \mathrm{N}$, $26.75367^{\circ} \mathrm{E}, 17.06 .2005 ; 32 . \mathrm{W}$ from Detelina village, Burgas distr., $42.56438^{\circ} \mathrm{N}, 27.02272^{\circ} \mathrm{E}, 11.07 .2005$; 33. W from Detelina village, Burgas distr., $42.56438^{\circ}$ $\mathrm{N}, 27.02272^{\circ} \mathrm{E}, 11.07 .2005$; 34 . N from Mirolyubovo village, Burgas distr., $42.65397^{\circ} \mathrm{N}, 27.36315^{\circ} \mathrm{E}$, 21.07.2005; 35. S from Palauzovo village, Yambol distr., $42.52381^{\circ} \mathrm{N}, 26.73799^{\circ} \mathrm{E}, 02.07 .2005$; 36. SW from Karnobat, Burgas distr., 29.06.2005; 37. E from Karnobat, Burgas distr., $42.64586^{\circ} \mathrm{N}, 27.02229^{\circ} \mathrm{E}$, 13.07.2005; 38. E from Malka polyana village, Burgas distr., $42.64233^{\circ} \mathrm{N}, 27.24806^{\circ} \mathrm{E}, 25.07 .2007 ; 39 . \mathrm{N}$ from Korten village, Sliven distr., $42.55508^{\circ} \mathrm{N}, 25.99200^{\circ}$ E, 12.07.2005; 40. between Karnobat and Dragantsi village, Burgas distr., $42.61250^{\circ} \mathrm{N}, 26.98975^{\circ} \mathrm{E}$, 05.07.2005; 41. Boztepe loc., E from Kamenovo village, Sliven distr., $42.54154^{\circ} \mathrm{N}, 26.13032^{\circ} \mathrm{E}, 19.07 .2004 ; 42$. Idemir hill, SW from Kermen, Sliven distr., $42.51616^{\circ}$ $\mathrm{N}, 26.24355^{\circ} \mathrm{E}, 18.07 .2004$; 43. Azmashka mogila loc., Hadzhi Dimitrovo village, Sliven distr., $42.53870^{\circ} \mathrm{N}$, 26.41424 ${ }^{\circ}$ E, 08.06.2004; 44. N from Sadievo village, Burgas distr., $42.66933^{\circ} \mathrm{N}, 27.32442^{\circ} \mathrm{E}, 23.07 .2005 ; 45$. $\mathrm{NE}$ from Bozadzhii village, Sliven distr., $42.48268^{\circ} \mathrm{N}$, $26.33966^{\circ} \mathrm{E}, 16.07 .2004 ; 46$. S from Konyovo village, Sliven distr., $42.51088^{\circ} \mathrm{N}, 26.16263^{\circ} \mathrm{E}, 19.07 .2004$; 47. $\mathrm{N}$ from Korten village, Sliven distr., $42.55640^{\circ} \mathrm{N}$, $25.98573^{\circ} \mathrm{E}, 12.07 .2005$; 48. N from Korten village, Sliven distr., $42.55554^{\circ} \mathrm{N}, 25.98958^{\circ}$ E, 12.07.2005; 49. Mirolyubovo village, Burgas distr., $42.63849^{\circ}$ $\mathrm{N}, 27.36152^{\circ} \mathrm{E}, 21.07 .2005$; 50. between Izvorishte and Bryastovets villages, Burgas distr., $42.66612^{\circ} \mathrm{N}$, 27.45120 ${ }^{\circ}$ E, 21.07.2005; 51. N from Sadievo village, Burgas distr., $42.66961^{\circ} \mathrm{N}, 27.32397^{\circ} \mathrm{E}, 23.07 .2005 ; 52$. E from Polski Gradets village, Sliven distr., $42.18546^{\circ}$ $\mathrm{N}, 26.12583^{\circ} \mathrm{E}, 21.07 .2004$; 53. between Izvorishte and Bryastovets villages, Burgas distr., 21.07.2005; 54. $\mathrm{N}$ from Kableshkovo village, Burgas distr., $42.67146^{\circ}$ $\mathrm{N}, 27.55190^{\circ} \mathrm{E}, 23.07 .2005$; 55. Sarnena Sredna gora Mt., between Staro selo and Kamenovo villages, Sliven distr., $42.56093^{\circ} \mathrm{N}, 26.14154^{\circ} \mathrm{E}, 19.07 .2004$;
56. W from Karnobat, Burgas distr., 29.06.2005; 57. E from Karnobat, Burgas distr., $42.64609^{\circ} \mathrm{N}$, 27.02644 ${ }^{\circ}$ E, 13.07.2005; 58. E from Karnobat, Burgas distr., $42.64801^{\circ} \mathrm{N}, 27.02742^{\circ} \mathrm{E}, 13.07 .2005$; 59. Hill between Kovachite and Mladovo villages, Sliven distr., $42.55644^{\circ} \mathrm{N}, 26.21116^{\circ} \mathrm{E}, 18.07 .2004$; 60. Hill between Chokoba and Bezmer villages, Yambol distr., $42.49382^{\circ} \mathrm{N}, 26.38229^{\circ} \mathrm{E}, 09.06 .2004 ; 61$. W from Kaloyanovo village, Sliven distr., $42.67240^{\circ} \mathrm{N}$, 26.44070 ${ }^{\circ}$ E, 23.06.2005; 62. S from Parvenets village, Yambol distr., 42.41694 $\mathrm{N}, 26.85969^{\circ} \mathrm{E}, 02.07 .2005$; 63. Malak Topchii hill, between Karnobat and Detelina village, Burgas distr., $42.60602^{\circ} \mathrm{N}, 27.00560^{\circ}$ $\mathrm{E}, 11.07 .2005 ; 64$. N from Korten village, Sliven distr., $42.55653^{\circ} \mathrm{N}, 25.98458^{\circ} \mathrm{E}, 12.07 .2005 ; 65$. W from Glufishevo village, Sliven distr., $42.54491^{\circ} \mathrm{N}$, 26.31444 ${ }^{\circ}$ E, 09.06.2004; 66. Hill between Veselinovo and Mogila villages, Yambol distr., $42.51435^{\circ} \mathrm{N}$, $26.57119^{\circ}$ E, 15.06.2004; 67. By the road YambolElhovo, $\mathrm{S}$ from cross-road to Tenevo village, Yambol distr., 15.07.2004; 68. S from Stamovo (Han Asparuh) village, $42.41620^{\circ} \mathrm{N}, 26.85365^{\circ} \mathrm{E}, 14.07 .2004 ; 69 . \mathrm{S}$ from Peshtersko village, Burgas distr., $42.73288^{\circ} \mathrm{N}$, $27.33456^{\circ} \mathrm{E}, 22.07 .2005$; 70. between Izvorishte and Bryastovets villages, Burgas distr., $42.66513^{\circ} \mathrm{N}, 27$. $45106^{\circ}$ E, 21.07.2005; 71. E from Karnobat, Burgas distr., $42.65403^{\circ} \mathrm{N}, 26.91887^{\circ} \mathrm{E}, 23.07 .2005 ; 72 . \mathrm{W}$ from Medovo, Burgas distr., $42.70296^{\circ} \mathrm{N}, 27.55550^{\circ} \mathrm{E}$, 23.07.2005; 73. E from Stratsin village, Burgas distr., $42.76537^{\circ} \mathrm{N}, 27.48149^{\circ} \mathrm{E}, 23.07 .2005$; 74. SE from Zhitosvyat village, Burgas distr., $42.45625^{\circ} \mathrm{N}, 26.98731^{\circ}$ $\mathrm{E}, 02.07 .2005 ; 75$. N from Mirolyubovo village, Burgas distr., $42.65403^{\circ} \mathrm{N}, 27.36101^{\circ} \mathrm{E}, 21.07 .2005 ; 76$. between Sadievo and Dryqnkovets villages, Burgas distr., $42.67826^{\circ} \mathrm{N}, 27.32107^{\circ} \mathrm{E}, 22.07 .2005$; 77. SW from Dragantsi village, Burgas distr., $42.56339^{\circ} \mathrm{N}$, $26.97769^{\circ}$ E, 05.07.2005; 78. N from Karanovo village, Burgas distr., $42.65030^{\circ} \mathrm{N}, 27.18485^{\circ} \mathrm{E}, 11.07 .2005$; 79. $\mathrm{N}$ from Hadzhiite village, Burgas distr., $42.61142^{\circ}$ N, 27.07072 ${ }^{\circ}$ E, 13.07.2005; 80. hills S from Kermen, Sliven distr., $42.49107^{\circ} \mathrm{N}, 26.27134^{\circ}$ E, 16.07.2004; 81. E from microdam, Nauchen village, Sliven distr., $42.55370^{\circ} \mathrm{N}, 26.08693^{\circ} \mathrm{E}, 20.07 .2004$.

Table 3: Relevés of the association Festuco valesiacaeStipetum capillatae Sillinger 1930.

Species occurring in $\mathbf{2}$ or fewer relevés: Ornithogalum umbellatum (K, Pont-subMed, 6;+); Dasypyrum villosum (H, subMed, 1:1, 4:1); Cichorium intybus (H, Eur-Sib, 1:r); Potentilla inclinata (H, Eur-As, 4:2a, 9:+); Plantago lanceolata $(\mathrm{H}, \mathrm{cosm}, 6:+)$; Galium tenuissimum (Th, Pont-CAs; 6:+); Achillea depressa (H, Bal, 7:1, 11:+); Trifolium retusum (Th, Med, 7:+); Centaurea caliacrae 
(Th, Bal, 7:+); Trifolium pallidum (Th, subMed, 6:+); Trachynia distachya (Th, Med-As, 9:+); Stachys germanica (H, Eur-subMed, 6:r); Bromusjaponicus (Th, Med-CAs, 1:+, 4:+); Nigella arvensis (Th, subMed, 1:+, 4:+); Phleum subulatum (Th, Eur-As, 4:+); Conyza canadensis (Th, Nam(adv), 1:+); Bilderdykia dumetorum (Th, Eur-Med, 4:+); Carduus acanthoides (H, Eur, 6:+); Tragus racemosus (Th, subBoreal, 7:+); Vicia sp. (6:+); Elymus repens $(\mathrm{H}$, Boreal, 6:+); Verbascum densiflorum (H, subMed, 6:r); Erysimum repandum (Th, Eur, As, 6:+, 7:+); Myosotis stricta (Th, Eur-As, 1:+); Trifolium cherleri (H, Med, 3:1, 8:+); Logfia arvensis (Th, Eur-Med, 6:r); Tribulus terrestris (Th, Eur-As, 1:1); Trifolium angustifolium (Th, Med, 1:+); Achillea coarctata (H, Pont-Med, 3:+, 10:+); Sanguisorba minor (H, subBoreal, 9:+, 10:+); Portulaca oleracea (Th, adv, 7:+); Sideritis montana (Th, subMed, 8:+, 9:+); Viscaria vulgaris subsp. atropurpurea (H, EurSib, 8:+); Viola arvensia (Th, Eur, 8:+); Onobrychis caputgali (Th, subMed, 9:2a); Acinos arvensis (Th, Eur-Med, 9:+); Linum bienne (Th, Med, 9:+); Salvia pratensis $(\mathrm{H}$, Eur-Med, 9:r); Sedum hispanicum (H, Eur-Med, 10:1); Daucus carota (Th, Eur-As, 9:r); Hypericum rumeliacum (H, Bal, 10:+); Koeleria simonkaii (H, Bal, 11:+); Stachys leucoglossa (H, Bal, 10:+); Velezia rigida (Th, subMed, 10:+); Alyssum strigosum (Th, subMed, 10:+); Trigonella monspeliaca (Th, subMed, 10:+); Orlaya grandiflora (Th, Ap-Bal, 10:+); Scrophularia canina (H, Eur-Med, 10:r); Bryum capillare (H, Temp, 10:+).

Localities: 1. NE from Izvorishte village, Burgas distr., $42.66149^{\circ} \mathrm{N}, 27.44725^{\circ} \mathrm{E}, 23.07 .2005 ; 2$. E from Venets village, Burgas distr., $42.64422^{\circ} \mathrm{N}, 26.36200^{\circ} \mathrm{E}$, 29.06.2005; 3. W from Nauchen village, Sliven distr., $42.56536^{\circ} \mathrm{N}, 26.08056^{\circ} \mathrm{E}, 20.07 .2004 ; 4$. NE from the town of Aytos, $42.72169^{\circ} \mathrm{N}, 27.24446^{\circ} \mathrm{E}, 25.07 .2005$; 5. E from Venets village, Burgas distr., $42.64373^{\circ}$ $\mathrm{N}, 26.86331^{\circ} \mathrm{E}, 29.06 .2005 ; 6$. Izvorishte village, Burgas distr., $42.65629^{\circ} \mathrm{N}, 27.43556^{\circ} \mathrm{E}, 21.07 .2005$; 7. between the town of Aytos and Peshtersko village $42.73009^{\circ} \mathrm{N}, 27.32797^{\circ} \mathrm{E}, 22.07 .2005$; 8. W from Gorno Aleksandrovo village, Sliven distr., $42.65694^{\circ}$ N, 26.61849º E, 16.06.2004; 9. Pamucite locality, NE from Polski Gradets village, Sliven distr., $42.19784^{\circ}$ $\mathrm{N}, 26.12378^{\circ} \mathrm{E}, 21.07 .2004 ; 10$. slopes of Sredna gora Mt., $\mathrm{N}$ from the villages of Bratya Kunchevi and Rumanya, Stara Zagora distr., $42.50638^{\circ} \mathrm{N}, 25.86973^{\circ}$ $\mathrm{E}, 22.07 .2004 ; 11$. N from Vratitsa village, Burgas distr., $42.59851^{\circ} \mathrm{N}, 27.17150^{\circ} \mathrm{E}, 11.07 .2005$.

Table 4: Relevés of the association Medicagini-Festucetum valesiacae Wagner 1941.

Species occurring in $\mathbf{2}$ or fewer relevés: Trifolium angustifolium (Th, Med, 2:+, 4:+); Lotus corniculatus (H, Eur-Med, 4:+, 8:+); Aegilops geniculata (Th, Med, 1:2m, 2:1); Carthamus lanatus (Th, subMed, 1:+, 2:+); Astragalus hamosus (H, Eur-as, 1:1, 6:+); Dianthus moesiacus (H, Bal, 3:+, 9:+); Dianthus pallens $(\mathrm{H}$, Bal-dac, 3:1); Marrubium peregrinum ( $\mathrm{H}$, subMed, 1:+, 11:+); Lolium perenne (H, Eur-As, 2:+); Trifolium pallidum (Th, subMed, 4:+); Bupleurum flavum (Th, Med, 4:+); Linum bienne (Th, Med, 4:+); Coronilla varia (H, Eur-Med, 4:+); Trachynia distachya (Th, Eur-As, 4:1, 10: 2m); Stachys germanica (H, Eur-subMed, 3:+); Hypochaeris radicata (H, Eur-Med, 5:+); Nigella arvensis (Th, subMed, 5:+); Trifolium setiferum (Th, Med, 3:+); Hypericum rumeliacum (H, Bal, 4:+); Phascum cuspidatum (H, Temp, 3:1); Ononis spinosa (H, Eur-As, 4:1, 10:r); Setaria viridis (Th, Boreal, 5:+); Bryum rubens $(\mathrm{H}, 3:+)$; Onobrychis gracilis s. Gracilis (H, Pont-Med, 4:r); Elymus repens (H, Boreal, 3:+); Phleum pratense $(\mathrm{H}$, Eur-subMed, 2:+); Ornithogalum umbellatum (K, PontsubMed, 3:+, 12:+); Centaurea stereophylla (H, Pont, 3:+); Cynodon dactylon (H, cosm, 7:+); Haplophyllum suaveolens $(\mathrm{H}, \mathrm{Med}, 6:+)$; (S) Onobrychis alba $(\mathrm{H}$, subMed, 6:+, 10:+); Velezia rigida (Th, subMed, 6:+); Potentilla pedata (H, Med, 6:+); Queria hispanica (Th, subMed, 6:+); Trifolium incarnatum (Th, subMed, 7:+); Trifolium suffocatum (Th, subMed, 7:+); Koeleria nitidula (H, Pont, 8:+); Medicago lupulina (Th, EurAs, 8:+); Trigonella monspeliaca (Th, subMed, 8:+); Dactylis glomerata (H, Eur-As, 8:r); Polygonum aviculare (Th, cosm, 9:+); Galium tenuissimum (Th, Pont-CAs, 9:+, 12:+); Achillea coarctata (H, Pont, Med, 10:+); Leonthodon crispus (H, Pont-Med, 11:+); Minuartia caespitosa (H, Eur-Med, 12:1); Scleranthus polycarpos (Th, subMed, 12:1); Sedum caespitosum (H, Med, 12:+); Portulaca oleracea (Th, adv, 12:+).

Localities:1. Hill between the villages of Veselinovo and Mogila, Yambol distr., $42.51435^{\circ} \mathrm{N}$, $26.57119^{\circ}$ E, 15.06.2004; 2. NE from Kamenets village, $42.34660^{\circ} \mathrm{N}, 26.75043^{\circ} \mathrm{E}, 01.07 .2004$; 3. E from Venets village, Burgas distr., 29.06.2005; 4. W from Polski Gradets village, Sliven distr., 21.07.2004; 5. E from Malka Polyana village, $42.62700^{\circ} \mathrm{N}$, $27.24925^{\circ}$ E, 25.07.2005; 6. Slopes of Stara planina Mt., N from Gorno Aleksandrovo village, Sliven distr., $42.65974^{\circ} \mathrm{N}, 26.63966^{\circ} \mathrm{E}, 16.06 .2004$; 7. Hill $\mathrm{S}$ from Zlati vojvoda village, Sliven distr., $42.57842^{\circ}$ $\mathrm{N}, 26.18539^{\circ} \mathrm{E}, 18.07 .2004$; 8. Svetiiliiski hills, Polsko Padarevo village, Sliven distr., $42.45191^{\circ} \mathrm{N}, 26.08582^{\circ}$ E, 11.06.2005; 9. S from town of Karnobat, $42.62766^{\circ}$ $\mathrm{N}, 26.99434^{\circ} \mathrm{E}, 05.07 .2005 ; 10 . \mathrm{N}$ from Korten village, Sliven distr., $42.55682^{\circ} \mathrm{N}, 25.98334^{\circ} \mathrm{E}, 12.07 .2005 ; 11$. Malak Topchii hill, between Karnobat and Detelina village, $42.60705^{\circ} \mathrm{N}, 27.00412^{\circ} \mathrm{E}, 11.07 .2005 ; 12 . \mathrm{E}$ from Dragantsi village, Burgas distr., $42.56876^{\circ} \mathrm{N}$, $26.98893^{\circ} \mathrm{E}, 05.07 .2005$. 
Table 5: Relevés of the association Trifolio arvensisFestucetum valesiacae Sopotlieva \& Apostolova 2013.

Species occurring in 2 or fewer relevés: Potentilla argentea $(\mathrm{H}$, Pont, 6:+, 7:2a); Cichorium intybus $(\mathrm{H}$, Eur-Sib, 2:r, 7:+); Medicago rigidula (Th, Eur-Med, 4:+, 5:+); Trifolium angustifolium (Th, Med, 4:+, 11:+); Polygonum aviculare (Th, cosm, 4:+, 5:+); Dasypyrum villosum (H, subMed, 2:+, 6:r); Vicia sp. (4:+ 5:+); Setaria viridis (Th, Boreal, 7:+); Carduus nutans (H, Eur, Med, 2:r, 9:r); Marrubium peregrinum (H, subMed, 1:r, 2:r); Centaurea caliacrae (Th, Bal, 6:+); Carthamus lanatus (Th, subMed, 1:+); Lolium perenne (H, Eur-As, 1:+); Bromus arvensis (Th, Eur-As, 1:+); Phleum subulatum (Th, Eur-As, 5:+); Berteroa incana $(\mathrm{H}$, Pont, 2:+); Ajuga genevensis ( $\mathrm{H}$, Pont, 9:2a); Bupleurum rotundifolium (Th, Eur-As, 2:r); Aegilops triuncialis (Th, Eur-As, 1:2a); Bilderdykia dumetorum (Th, Eur-Med, 5:+); Carduus acanthoides (H, Eur, 4:+); Tragopogon dubius (H, Eur-Med, 2:r, 9:r); Tragus racemosus (Th, subBoreal, 5:+); Euphorbia agraria ( $\mathrm{H}$, subMed, 9:1); Hypericum thasium (H, Bal, 3:r); Astragalus hamosus (H, Eur-As, 1:+); Iris suaveolens (K, Bal, 9:+); Brachythecium rutabulum (H, Temp, 9:+); Hypnum cupressiforme (H, Temp, 9:+); Potentilla pedata (H, Med, 9:1); Portulaca oleracea (Th, adv, 5:+); Centaurea solstitialis (Th, Eur-Med, 4:+); Sanguisorba minor (H, subBoreal, 4:+, 11:+); Leontodon cichoraceus ( $\mathrm{H}$, subMed, 4:r); Bupleurum affine (Th, subMed, 4:+); Medicago orbicularis (Th, Eur-Med, 5:+); Allium vineale (K, Eur-Nam, 6:+); Dianthus moesiacus $(\mathrm{H}$, Bal, 6:+, 8:+); Thesium simplex (H, Bal-dac, 6:r); (S) Anagallis arvensis (Th, cosm, 7:+); Tragopogon pratensis (H, Eur-Med, 8:r); Coronilla varia (H, Eur-Med, 8:+); Phascum cuspidatum (H, Temp, 8:+); Centaurea stereophylla (H, Pont, 8:+); Phlomis herba-ventis $(\mathrm{H}$, Eur-As, 8:+); Euphorbia nicaeensis (H, Eur-Med, 8:+); Bryum rubens (H, 8:+); Inula hirta (H, Eur-Sib, 10:+); Carduus candicans subsp. globifer (H, 10:+); Dianthus armeria (Th, Eur, 10:+); Lotus corniculatus (H, EurMed, 11:+).

Localities: 1. Drakata loc., NW from Slamino, Yambol distr., 11.06.2004; 2. E from the town of Karnobat, 42.64695 ${ }^{\circ} \mathrm{N}, 27.02333^{\circ} \mathrm{E}, 13.07 .2005 ; 3$. Slivova mogila hill, town of Tvarditsa $42.68585^{\circ} \mathrm{N}$, $25.91407^{\circ} \mathrm{E}, 09.06 .2005 ; 4$. SW from Izvorishte village, Burgas distr., $42.65685^{\circ} \mathrm{N}, 27.43546^{\circ} \mathrm{E}, 21.07 .2005 ; 5$. SE from Bryastovets village, Burgas distr., $42.66712^{\circ}$ $\mathrm{N}, 27.47598^{\circ}$ E, 21.07.2005; 6. Peshtersko village, Burgas distr., $42.73028^{\circ} \mathrm{N}, 27.32726^{\circ} \mathrm{E}, 22.07 .2005$; 7. SW from Bata village, Burgas distr., $42.73011^{\circ} \mathrm{N}$, $27.48065^{\circ} \mathrm{E}, 23.07 .2005$; 8. E from Venets village, Burgas distr., $42.64110^{\circ} \mathrm{N}, 26.84054^{\circ} \mathrm{E}, 29.06 .2005$; 9. S from Malenovo village, Yambol distr., $42.55194^{\circ}$
N, 26.76805 E, 22.06.2005; 10. between Sokolova and Dragovo villages, Burgas distr., 42.63995 $\mathrm{N}$, $27.08967^{\circ}$ E, 13.07.2005; 11. Ognen village, Burgas distr., $42.69614^{\circ} \mathrm{N}, 26.80961^{\circ} \mathrm{E}, 26.06 .2005$.

Table 6: Relevés of the community of Chrysopogon gryllus.

Species occurring in 2 or fewer relevés: Cynosurus echinatus (H, subMed, 9:3); (S) Elymus hispidus $(\mathrm{H}$, Pont-CAs, 1:2m); Tragopogon pratensis $(\mathrm{H}$, EurMed, 5:r); Trifolium hybridum (H, Eur-Med, 3:+, 8:+); Dianthus armeria (Th, Eur, 7:+, 8:r); Cynodon dactylon (H, Cosm, 5:+);Torilis nodosa (Th, Eur-As, 1:+); Bromus tectorum (Th, Boreal, 9:1); Bromus mollis (Th, Boreal, 8:1); Echium vulgare (H, Eur-As, 7:r); (H, Cosm, 9:+, 10:+); Convolvulus arvensis (H, Cosm, 9:+, 10:+);(S) Trifolium repens (H, Eur-Sib, 7:+); Dasypyrum villosum (H, subMed, 4:+, 10:2m); Veronica arvensis (Th, EurSib, 1:+); Geranium rotundifolium (Th, Eur-As, 9:r); Bromus arvensis(Th, Eur-As, 4:2b); Vulpia ciliata (Th, Med-As, 7:+); Hordeum bulbosum (H, Eur-As, 4:+); Apera spica-venti (Th, subBoreal, 10:+); Cichorium intybus (H, Eur-Sib, 5:+, 10:r); (S) Taraxacum sp. (H, 8:+); Rumex pulcher (H, Eur-As, 1:r); Tragopogon dubius $(\mathrm{H}$, Eur-Med, 9:r); Berteroa incana $(\mathrm{H}$, Pont, 9:1); Vulpia myurus (Th, subBoreal, 9:1); Lotus angustissimus (Th, Med-As, 6:1); Poa pratensis $(\mathrm{H}$, Cosm, 6:2m); Rorippa thracica (H, subMed, 9:+); Nigella arvensis (Th, subMed, 1:+); Filago vulgaris (Th, Eur-As, 6:1, 7:+); Trifolium scabrum (Th, Med-As, 10:+, 11:+); Bromus squarrosus (Th, subMed, 4:+); Torilis arvensis (Th, Eur-As, 6:+); Hypochaeris radicata $(\mathrm{H}$, Eur-Med, 7:r, 8:+); Trifolium pallidum (Th, subMed, 5:+, 11:+); Vicia grandiflora (Th, subMed, 5:+); Agrimonia eupatoria (H, Eur-Med, 9:r); Achillea collina (H, EursubMed, 6:+); (S) Elymus elongatus (H, Pont-SMed, 6:3); Agrostis capillaris (H, Boreal, 4:+); Filipendula vulgaris (H, Eur-Med, 8:+); Paliurus spina-christi (Ch, Eur-As, 9:r); Galium verticillatum (Th, Med-As, 9:+); Vicia hirsuta (Th, Eur-Med, 1:+); Goniolimon collinum (H, Pont, 10:2a); Trifolium aureum (Th, Eur-Sib, 8:1); Viola tricolor (Th, Eur-As, 9:+); Galium aparine (Th, Eur-As, 9:+); Poa sylvicola (H, Eur-As, 4:+); Nonea pulla (Th, subMed, 2:r, 10:+); Phleum subulatum (Th, EurAs, 10:3); Poa angustifolia (H, Cosm, 9:+); Achillea crithmifolia (H, Pann-Bal, 8:+); Bupleurum flavum (Th, Med, 4:+); Galium tenuissimum (Th, Pont-CAs, 1:+, 7:+); Phleum pratense (H, Eur-subMed, 6:+); Bromus japonicus (Th, Med-CAs, 10:2m); Minuartia caespitosa (H, Eur-Med, 8:+); Potentilla pedata (H, Med, 3:+); Ajuga genevensis (H, Pont, 10:+); Medicago minima (Th, Eur-As, 2:+);Helianthemum nummularium (Ch, Alp-Med, 2:2m); Medicago falcata (H, Eur-As, 2:+); 
Carthamus lanatus (Th, subMed, 2:+); Asyneuma anthericoides $(\mathrm{H}, \mathrm{Bal}, 2:+)$; Trifolium arvense(Th, EurSib, 11:1); Fumana procumbens (Ch, Pont-Med, 11:+); Potentilla pilosa (H, Eur, 11:+); Allium vineale (K, EurNam, 11:+); Hypericum rumeliacum (H, Bal, 11:+); Phleum phleoides (H, Eur-As, 11:+); Scleranthus perennis (H, Eur-Med, 11:+); Herniaria hirsuta (Th, Eur-As, 11:+); Centaurea caliacrae(Th, Bal, 11:+); Haplophyllum suaveolens (H, Med, 11:+); Centaurea diffusa (H, PontMed, 11:+); Syntrichia ruralis (H,Cosm; Temp, 11:+); Erysimum repandum (Th, Eur-As, 11:+); Erodium cicutarium (Th, subBoreal, 11:r); Ceratodon purpureus (H, Cosm; Temp, 11:+); Portulaca oleracea (Th, Adv, 11:+); Trifolium retusum (Th, Med, 11:+); Carduus acanthoides (H, Eur, 11:+);

Localities: 1. N from Venets village, Burgas distr., $42.64406^{\circ} \mathrm{N}, 26.80502^{\circ}$ E, 26.06.2005; 2. between Veselinovo and Mogila villages, Yambol distr., $42.51435^{\circ} \mathrm{N}, 26.57119^{\circ} \mathrm{E}, 15.06 .2004$; 3. E from Devetintsi village, Burgas distr., $42.59531^{\circ} \mathrm{N}, 26.83205^{\circ}$ E, 23.06.2005; 4. W from Savino village, Yambol distr., $42.33759^{\circ} \mathrm{N}, 26.27544^{\circ} \mathrm{E}, 29.06 .2004 ; 5$. NE from Elenovo village, Sliven distr., $42.38495^{\circ} \mathrm{N}, 26.15897^{\circ}$ E, 14.06.2004; 6. S from Stamovo (Han Asparuh) village, Stara Zagora distr., 14.07.2004; 7. Svetiiliski hills, between Ezero and Radevo villages, Sliven distr., $42.44348^{\circ} \mathrm{N}, 26.06228^{\circ} \mathrm{E}, 11.06 .2005$; 8. Kayriaka hill, S from Hanovo, Yambol distr., 08.06.2004; 9. Svetiiliski hills, $42.42224^{\circ} \mathrm{N}, 26.13721^{\circ} \mathrm{E}, 11.06 .2006$; 10. SW from the town of Karnobat, $42.63281^{\circ} \mathrm{N}, 26.94546^{\circ} \mathrm{E}$, 29.06.2005; 11. Dabnik village, Burgas distr., $42.63643^{\circ}$ $\mathrm{N}, 27.51047^{\circ} \mathrm{E}, 21.07 .2005$.

Table 7: Relevés of the association Euphorbio myrsinitae-Bothriochloetum ischaemi R. Jovanović 1955 subass. medicaginetosum rhodopaeae Sopotlieva \& Apostolova 2013.

Species occurring in $\mathbf{2}$ or fewer relevés: Carduus nutans (H, Eur-Med, 9:r, 19:r); Hypericum thasium $(\mathrm{H}$, Bal, 8:+, 9:r); Cerastium pumilum (Th, Eur-Med, 6:+, 9:+); Taeniatherum caput-medusae (Th, Eur-As, 7:r, 9:+); Muscari sp. (K, 7:+, 19:+); Reseda lutea (H, subBoreal, 14:r); Coronilla scorpioides (Th, subMed, 16:+); Echium vulgare (H, Eur-As, 6:r); Phleum subulatum (Th, EurAs, 7:r); Veronica arvensis (Th, Eur-Sib, 6:+); Iris sp. (K, 7:r); Achnatherum bromoides (H, subMed16:1); Anthericum liliago (H, subMed, 17:+); Phascum cuspidatum (H, Temp, 18:+); Bryum argenteum $(\mathrm{H}$, Temp, 12:+); Tortella flavovirens ( $\mathrm{H}$, subMed, 5:1); Weissia controversa (H, Temp, 13:1); Petrorhagia prolifera (Th, Pont-Med, 18:+, 22:+); Vulpia myurus (Th, subBoreal, 7:+); Tragopogon dubius (H, Eur-
Med, 3:+); Trifolium cherleri (H, Med, 6:r); Ceratodon purpureus (H, Temp, 14:+); Galium tenuissimum (Th, Pont-CAs, 9:+); Velezia rigida (Th, subMed, 14:+); Onobrychis degenii (H, Bal, 15:r); Centaurea salonitana (H, Pont-Med, 16:r); Galium octonarium (H, Med-CAs, 16:+); Bupleurum apiculatum (Th, Bal, 15:2a); Anthemis tinctoria (H, Eur-Sib, 10:r), Genista sessilifolia s. Trifoliata (Ch, subMed, 10:2a); Potentilla sulphurea (H, subMed, 13:r); Asyneuma limonifolium s. limonifolium (H, Ap-Bal, 17:r); Pterocephalus papposus (Th, Med, 20:+); Crepis sancta (Th, subMed, 20:r); Koeleria simonkaii (H, Bal, 20:r); Verbascum banaticum (H, Bal-Dac, 20:r); Scrophularia canina (H, Eur-Med, 20:r); Alyssum alyssoides (Th, Eur-Med, 20:+); Achillea coarctata (H, Pont-Med, 21:1); Stachys leucoglossa (H, Bal, 21:-); Dianthus pinifolius (H, Bal-Dac, 21:+); Potentilla pilosa (H, Eur, 21:+); Centaurea caliacrae (Th, Bal, 22:+); Trigonella monspeliaca (Th, subMed, 22:+).

Localities: 1. S from the town of Shivachevo, Karabair hill, $42.63708^{\circ} \mathrm{N}, 26.06470^{\circ} \mathrm{E}, 19.07 .2005 ; 2$. Tvarditsa town, Tepyata hill, $42.68141^{\circ} \mathrm{N}, 25.95564^{\circ}$ E, 09.06.2005; 3. Karabair hill, Binkos village, $42.64122^{\circ}$ N, $26.08435^{\circ}$ E, 15.06.2005; 4. Karabair hill, Binkos village, $42.65040^{\circ} \mathrm{N}, 26.09269^{\circ} \mathrm{E}, 15.06 .2005$; 5. Tvarditsa town, Golina hill, $42.68245^{\circ} \mathrm{N}, 25.92630^{\circ}$ E, 09.06.2005; 6. Tvarditsa town, Golina hill,, $42.68375^{\circ} \mathrm{N}, 25.92518^{\circ} \mathrm{E}, 09.06 .2005$; 7. Svetiiliyski hills, $42.43351^{\circ} \mathrm{N}, 26.15047^{\circ} \mathrm{E}, 11.06 .2005 ; 8$. Tvarditsa town, Tepyata hill, 09.06.2005; 9. Tvarditsa town, Tepyata hill, $42.68164^{\circ} \mathrm{N}, 25.95451^{\circ} \mathrm{E}, 09.06 .2005 ; 10$. Karabair hill, Binkos village, $42.64068^{\circ} \mathrm{N}, 26.08257^{\circ}$ E, 15.06.2005; 11. S from Shivachevo town, Karabair hill, $42.63763^{\circ} \mathrm{N}, 26.06706^{\circ} \mathrm{E}, 19.07 .2005 ; 12$. Shivachevo town, close to old lime-kilns, $42.63709^{\circ}$ $\mathrm{N}, 26.03591^{\circ}$ E, 19.07.2005; 13. Svetiiliyski hills, Dyadovo village, $42.43958^{\circ} \mathrm{N}, 26.03478^{\circ} \mathrm{E}, 11.07 .2005$; 14. S from the town of Shivachevo, Karabair hill, $42.65076^{\circ} \mathrm{N}, 26.03798^{\circ} \mathrm{E}, 19.07 .2005$; 15 . Shivachevo town, close to old lime-kilns, $42.63743^{\circ} \mathrm{N}, 26.03710^{\circ}$ E, 19.07.2005; 16. Between the villages of Binkos and Seliminovo, 42.64787 ${ }^{\circ} \mathrm{N}, 26.12901^{\circ}$ E, 15.07.2005; 17. Between the villages of Binkos and Seliminovo, $42.64885^{\circ} \mathrm{N}, 26.12825^{\circ} \mathrm{E}, 15.07 .2005 ; 18$. S from the town of Shivachevo, Karabair hill, $42.65268^{\circ} \mathrm{N}$, $26.03948^{\circ}$ E, 19.07.2005; 19. Karabair hill, Binkos village, $42.65061^{\circ} \mathrm{N}, 26.09136^{\circ} \mathrm{E}, 15.06 .2005 ; 20$. South slopes of East Stara planina Mt., N from Glushnik village, Sliven distr., $42.66522^{\circ} \mathrm{N}, 26.50144^{\circ}$ E, 05.06.2004; 21. N from Karanovo village, Sliven distr., $42.51823^{\circ} \mathrm{N}, 25.89938^{\circ} \mathrm{E}, 22.07 .2004 ; 22 . \mathrm{N}$ from Asenovets village, Sliven distr., $42.54326^{\circ} \mathrm{N}$, 25.94406 ${ }^{\circ}$ E, 12.07.2005. 